\title{
RELAÇÃO ENTRE USO DA TERRA E COMPOSIÇÃO DE INSETOS AQUÁTICOS DE QUATRO BACIAS HIDROGRÁFICAS DO ESTADO DE SÃO PAULO
}

KATHIA CRISTHINA SONODA

Tese apresentada à Escola Superior de Agricultura "Luiz de Queiróz", Universidade de São Paulo, para obtenção do título de Doutor em Ecologia de Agroecossistemas.

P I R A C I C A B A

Estado de São Paulo - Brasil

Maio - 2005 


\title{
RELAÇÃO ENTRE USO DA TERRA E COMPOSIÇÃO DE INSETOS AQUÁTICOS DE QUATRO BACIAS HIDROGRÁFICAS DO ESTADO DE SÃO PAULO
}

\author{
KATHIA CRISTHINA SONODA \\ Bacharel em Ciências Biológicas
}

Orientador: Prof. Dr. Carlos Alberto VetTorazzi Co-orientador: Profa. Dra. SuSANA TRIVINHO-STRIXINO

\begin{abstract}
Tese apresentada à Escola Superior de Agricultura "Luiz de Queiróz", Universidade de São Paulo, para obtenção do título de Doutor em Ecologia de Agroecossistemas.
\end{abstract}

P I R A C I C A B A

Estado de São Paulo - Brasil

Maio - 2005 
Dados Internacionais de Catalogação na Publicação (CIP) DIVISÃO DE BIBLIOTECA E DOCUMENTAÇÃO - ESALQ/USP

Sonoda, Kathia Cristhina

Relação entre uso da terra e composição de insetos aquáticos em quatro bacias hidrográficas do Estado de São Paulo / Kathia Cristhina Sonoda. - - Piracicaba, 2005. 124 p. : il

Tese (doutorado) - - Escola Superior de Agricultura Luiz de Queiroz, 2005. Bibliografia.

1. Análise estatística 2. Bacia hidrográfica 3. Classificação - Biologia 4. Ecologia animal 5. Geoprocessamento 6. Inseto aquático 7. Mapa de uso da terra I. Título

CDD 595.705

\section{"Permitida a cópia total ou parcial deste documento, desde que citada a fonte - O autor"}




\section{AGRADECIMENTOS}

A Deus;

À minha família;

À FAPESP e à Pró-Reitoria de Pós-Graduação da USP, por todo tipo de ajuda recebida; Ao Prof. Dr. Carlos Alberto Vettorazzi, pela acolhida;

À Coordenação do PPGI, sempre presente;

À ESALQ;

À Profa. Dra. Susana Trivinho-Strixino, UFSCar, pela amizade e sugestões pertinentes; Dr. Alexandre da Silva, por permitir utilizar os mapas digitais das bacias estudadas; Ao Prof. Dr. Colin Townsend e ao Dr. Christoph Matthaei, University of Otago, pela vivência profissional em Dunedin e pela acolhida em seu país;

Prof. Dr. Cláudio Froehlich, FFCLRP-USP, pelos comentários e correções, e sua equipe, em especial a Rodolfo Mariano, pela identificação dos Ephemeroptera; Prof. Edwin Ortega, ESALQ, por parte das análises estatísticas aqui apresentadas; Aos Profs. Drs. Reynaldo Victória e Silvia Molina Guerra pelo apoio durante o curso; À Dra. Roberta Valente, pela ajuda com os softwares de geoprocessamento; À equipe de funcionários e alunos do Laboratório de Ecologia Isotópica-CENA/USP pela ajuda no campo e no laboratório, com especial agradecimento ao Ricardo Signoretti e ao Rodrigo Menuzzo, meus estagiários e amigos;

Aos moradores da Vila Estudantil da Pós-Graduação da ESALQ, pela companhia; À Maestrina Cíntia Pinotti e a todos os integrantes do Coral Luiz de Queiróz; À Oficina de flauta doce da ESALQ e à companheira de aulas, Cínthia Costa; Ao casal Raquel Silveira e Conrado Spínola, amigos de todas as horas;

À todos que direta ou indiretamente participaram deste processo;

Obrigada. 


\section{SUMÁRIO}

Página

LISTA DE FIGURAS.......................................................................... vii

LISTA DE TABELAS........................................................................ ix

LISTA DE SIGLAS, ABREVIATURAS E SÍMBOLOS............................ xi

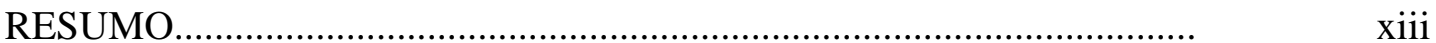

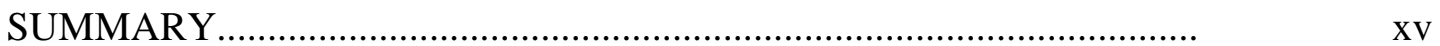

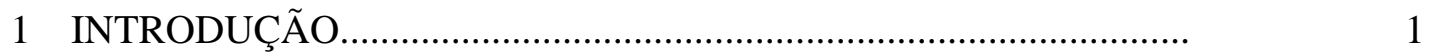

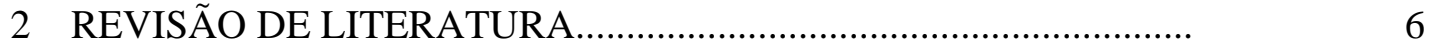

3 MATERIAL E MÉTODOS........................................................... 29

3.1 Área de Estudo........................................................................ 29

3.1.1 Bacia Hidrográfica do Alto Paranapanema.................................... 29

3.1.2 Bacias Hidrográficas dos rios do Peixe e Aguapeí........................... 31

3.1.2.1 Bacia do rio Aguapeí....................................................................

3.1.2.2 Bacia do rio do Peixe...................................................................

3.1.3 Bacia Hidrográfica do rio São José dos Dourados.......................... 33 
3.2 Estudo em Escala Regional............................................................. 33

3.2.1 Coleta dos Insetos Aquáticos....................................................... 33

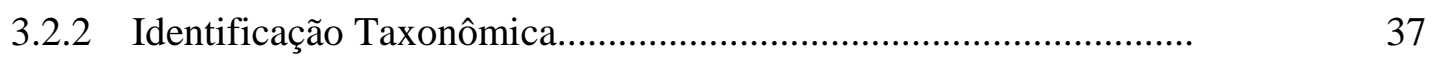

3.2.3 Confecção e Classificação dos Mapas de Uso da Terra................... 37

3.2.4 Análises Químicas e Físicas da Água............................................ 39

3.2.5 Análise dos Resultados................................................................ 39

3.3 Estudo em Escala Local.............................................................

3.3.1 Coleta dos Insetos Aquáticos........................................................ 42

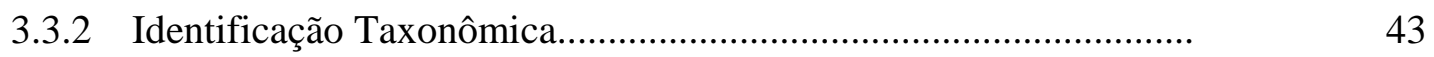

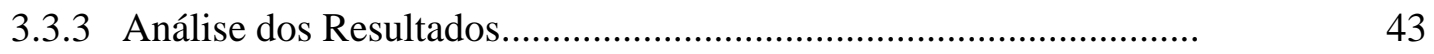

$4 \quad$ RESULTADOS ................................................................

4.1 Estudo em Escala Regional........................................................ 45

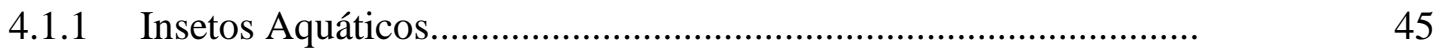

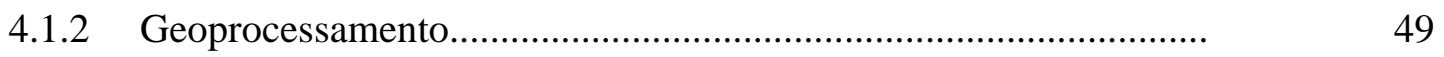

4.1.3 Análises Estatísticas.............................................................

4.2 Estudo em Escala Local.............................................................. 61

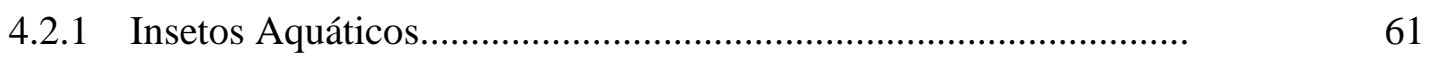

4.2.2 Análises Estatísticas................................................................... 
5 DISCUSSÃO

5.1 Estudo em Escala Regional................................................................

$5.2 \quad$ Estudo em Escala Local................................................................

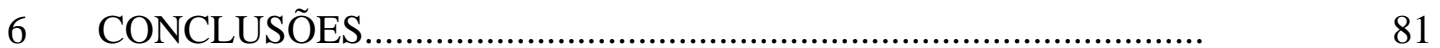

6.1 Considerações Finais.....................................................................

6.1 Estudo em Escala Regional...........................................................

6.2 Estudo em Escala Local.................................................................

ANEXOS

REFERÊNCIAS BIBLIOGRÁFICAS....................................................... 


\section{LISTA DE FIGURAS}

Página

1 Representação do estado de São Paulo com indicação dos pontos de coleta

2 Esquema da disposição das réplicas ao longo do rio

3 Disposição dos cestos em cada lote

4 Cesto depredado, detalhe das pedras boiando próximas ao mesmo ........

5 Retirada de cesto de substrato artificial do rio e acondicionamento em saco plástico

6 Esquema da disposição das réplicas ao longo do rio

7 Detalhe da disposição dos cesto de substratos artificiais nas margens nos pontos amostrais

8 Mapas dos usos da terra das sub-bacias. Em A - Paranapanema; B Apiaí-Guaçu; C - Peixe; D - Taquari; E - Aguapeí e F - São José dos Dourados

9 Mapas dos usos da terra das sub-bacias. Em A - Paranapanema; B Apiaí-Guaçu; C - Peixe; D - Taquari; E - Aguapeí e F - São José dos Dourados 
10 Classes de declividade em cada sub-bacia. Em A - Paranapanema; B Apiaí-Guaçu; C - Peixe; D - Taquari; E - Aguapeí e F - São José dos Dourados

11 Classes de declividade nas zona tampão das sub-bacias. Em A Paranapanema; B - Apiaí-Guaçu; C - Peixe; D - Taquari; E 56 Aguapeí e F - São José dos Dourados

12 Relação entre as famílias mais abundantes e os rios estudados, pela análise de correspondência

13 Análise de correspondência dos gêneros principais e os rios estudados .

14 Número total de Chironomidae relacionado ao uso da terra em cada rio. Asterisco marca a influência da pastagem

15 Distribuição dos quatro gêneros mais abundantes em cada uso da terra por rio. Asteriscos marcam a influência da pastagem 


\section{LISTA DE TABELAS}

Página

1 Informações sócio-econômicas das bacias hidrográficas estudadas

2 Informações sobre os locais de coleta na bacia do Alto Paranapanema ...

3 Listagem dos táxons coletados em cada rio e seus respectivos número de indivíduos

4 Valores dos índices comunitários de cada comunidade amostrada

5 Chironomidae amostrados nas bacias hidrográficas, em número de indivíduos

6 Índices comunitários da fauna de Chironomidae dos rios

7 Valores médios das variáveis químicas e físicas analisadas entre julho e setembro/2001

8 Famílias amostradas nos trechos de mata, em número total de indivíduos

9 Famílias amostradas nos trechos de pastagem, em número total de indivíduos.

10 Valores dos índices comunitários das famílias amostradas nos trechos de mata ripária e pastagem 
11 Gêneros de Chironomidae, em número total de indivíduos, provenientes dos trechos com mata ripária

12 Táxons de Chironomidae amostrados nos trechos de pastagem de ambos os rios, em número absoluto de indivíduos

13 Valores dos índices comunitários das comunidades de cada uso da terra e rio

14 Valor da ANOVA (r) e significância para as variáveis dependentes de acordo com os três fatores analisados. Valores significantes são marcados com asterisco 


\section{LISTA DE SIGLAS, ABREVIATURAS E SÍMBOLOS}

$\begin{array}{cl}\text { FSS } & \text { Sólidos suspensos finos } \\ \text { TEMP } & \text { Temperatura } \\ \text { PH } & \text { pH } \\ \text { COND } & \text { Condutividade } \\ \text { OD } & \text { Oxigênio dissolvido } \\ \text { DOC } & \text { Carbono orgânico dissolvido } \\ \text { DIC } & \text { Carbono inorgânico dissolvido } \\ \text { CO2LIVRE } & \text { Monóxido de carbono livre na água } \\ \text { CL } & \text { Íon cloreto } \\ \text { NO2 } & \text { NO } 2 \\ \text { NO3 } & \text { NO } \\ \text { SO4 } & \text { SO } \\ \text { NA } & \text { Sódio } \\ \text { NH4 } & \\ \text { K } & \text { Potássio } \\ \text { MG } & \text { Magnésio } \\ \text { CA } & \text { Cálcio } \\ \text { AREIA } & \\ \text { SILTE } & \\ \text { ARGILA } & \\ \text { SBPT } & \text { sub-bacia pastagem } \\ \text { SBCPER } & \text { sub-bacia cultura perene } \\ \text { SBVEG } & \text { sub-bacia vegetação remanescente } \\ \text { SBCN } & \text { sub-bacia cana-de-açúcar } \\ \text { SBREFL } & \text { sub-bacia reflorestamento } \\ \text { SBAG } & \text { sub-bacia corpos d'água } \\ \text { SBCTEMP } & \text { sub-bacia cultura temporária } \\ \text { SBSL } & \text { sub-bacia solo exposto } \\ \text { SBURB } & \text { sub-bacia área urbana } \\ \text { SBOUT } & \text { sub-bacia outros } \\ \text { BFPT } & \text { buffer pastagem } \\ & \end{array}$




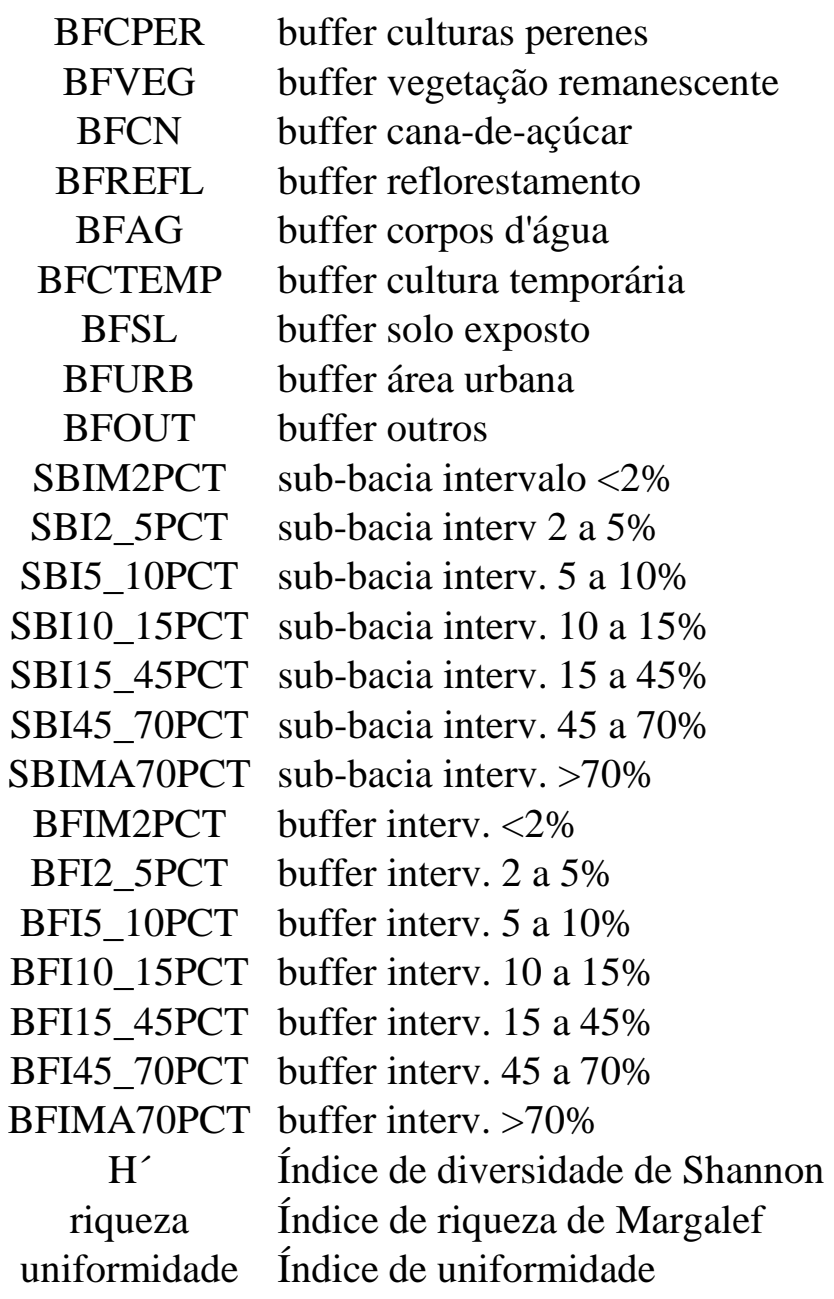




\title{
RELAÇÃO ENTRE USO DA TERRA E COMPOSIÇÃO DE INSETOS AQUÁTICOS DE QUATRO BACIAS HIDROGRÁFICAS DO ESTADO DE SÃO PAULO
}

\author{
Autora: KATHIA CRISTHINA SONODA \\ Orientador: PROF. DR. CARLOS ALBERTO VETTORAZZI \\ Co-orientador: Profa. Dra. SUSANA TRIVINHO-STRIXINO
}

\section{RESUMO}

1. Avaliar diferenças nas comunidades de insetos aquáticos de quatro bacias hidrográficas do estado de São Paulo com diferentes graus de ocupação, relacionando-as em função dos usos da terra e declividade do terreno na sub-bacia a montante dos locais de coleta e em uma zona tampão de 50m, assim como em função de variáveis químicas e físicas da água. 2. Avaliar alterações nas comunidades de insetos aquáticos provenientes de locais com presença ou ausência de mata ripária nas margens. Os dados referem-se às coletas de insetos aquáticos com cestos com substrato artificial; estes ficaram 44 dias em exposição, entre agosto e outubro de 2002. As bacias estudadas foram Alto Paranapanema, Peixe, Aguapeí e São José dos Dourados. Para o primeiro estudo, seis amostras de cada rio foram tomadas, cujas faunas foram identificadas e contadas; Chironomidae foram identificados em nível genérico, os demais insetos, em família. Para interpretação dos resultados, utilizou-se números absoluto e percentual de indivíduos e táxons; índices de diversidade, riqueza, uniformidade e quantidade de táxons de Ephemeroptera, Plecoptera e Trichoptera. Para o geoprocessamento, a partir de mapas digitais, delimitou-se a sub-bacia a montante dos locais de coleta e a zona tampão de $50 \mathrm{~m}$ ao redor dos rios, para cálculo da percentagem dos usos da terra e da declividade. Para as análises estatísticas, utilizou-se o índice de correlação de Pearson, análise de variância e análise de correspondência. Para o segundo estudo, amostras provenientes dos rios Aguapeí e São José dos Dourados foram tomadas. A fauna foi 
identificada nos mesmos níveis taxonômicos que o outro estudo. Como resultado do primeiro estudo, trinta e uma famílias foram identificadas, com dominância de Elmidae, Leptohyphidae, Leptophlebiidae, Chironomidae, Simuliidae e Hydropsychidae. Dente as variáveis da água testadas, dez foram capazes de caracterizar os rios. Os usos da terra também foram característicos de alguns rios. Estudo 2. Neste estudo foi encontrado menor número de indivíduos e de táxons nas amostras de mata, entretanto, as análises estatísticas demonstraram que a maior riqueza está relacionada aos locais de mata. Os resultados destes dois estudos permitiram inferir que a preservação da mata ripária imediatamente adjacente ao local é que influencia na comunidade de insetos aquáticos. Os elevados números de indivíduos e de táxons encontrados nos rios das bacias de maior grau degradação pode estar relacionado ao fato controverso de haver um corredor de mata ripário mais bem preservado ao longo destes rios que naqueles de menor ocupação antrópica. Até o presente estudo, pouco era conhecido sobre a entomofauna aquática dos rios aqui estudados; novos táxons foram encontrados, aumentando o conhecimento sobre a diversidade no estado. Outros estudos são necessários para verificar sobre a influência local da mata ripária sobre a comunidade de insetos aquáticos. 


\title{
RELATIONSHIP OF LAND USE AND COMPOSITION OF AQUATIC INSECTS FROM FOUR WATERSHEDS OF SÃO PAULO STATE
}

\author{
Author: KATHIA CRISTHINA SONODA \\ Adviser: Prof. Dr. CARLOS ALBERTO VETTORAZZI \\ Co-Adviser: Profa. Dra. SUSANA TRIVINHO-STRIXINO
}

\section{SUMMARY}

1. To evaluate differences in the aquatic insects communities of four watersheds from the State of São Paulo showing different degrees of human occupation, relating them to the landuses and terrain slope of the watershed and the 50m's buffer zone upstream of the sample sites as well as in relation to the chemical and physical water variables. 2. To evaluate alterations in the aquatic insects communities living in places showing presence/absence of riparian forest. The data were based on samples of aquatic insects collected with artificial substrates baskets; the exposure time was 44 days between August and October/2002. The watersheds studied were Alto Paranapanema, Peixe, Aguapeí and São José dos Dourados. For the first study, six samples were taken from each river and the fauna was identified and counted, Chironomidae were identified until genus level while the other insects, until family. To analyze the results, total and percentage numbers of individuals and taxons were used, as well as some community indexes, diversity, richness, evenness and total number of Ephemeroptera, Plecoptera and Trichoptera. For the remote sensing methods, information about the watersheds and the 50m's buffer zone upstream the sample sites were generated from digital maps. The landuses and terrain slope of those areas were calculated. Pearson's correlation index, analysis of variance and analysis of correspondence were used for the statistical analyses. For the second study, samples from Aguapeí and São José dos Dourados rivers were taken. The faunas were identified in the same levels following the other study. As result of the first study, thirty-one families were identified. Elmidae, Leptohyphidae, Leptophlebiidae, Chironomidae, Simuliidae and Hydropsychidae showed numeric dominance. Ten out 19 chemical and physical variables tested were able to characterize the rivers. The land uses were characteristic of some rivers as well. Study 2. In that study, the samples from forest showed fewer numbers of individuals and taxons, 
although the statistical analysis showed that, in fact, the greatest richness was associated to places where the forest was present. Both studies permitted us to make the inference that the forest immediately adjacent to the sample site is the most important factor for that fauna. The highest numbers of individuals and taxons from rivers with greatest impacted watersheds may be related to the presence of a better preserved riparian forest surrounding the rivers. Until the present study, little was known about the entomological aquatic fauna of those rivers; new taxons were found increasing the knowledge about the diversity of the State. Other studies are necessary to confirm about the local influence of riparian forest on the insect's aquatic community. 


\section{INTRODUÇÃO}

Um efeito resultante do crescimento do contingente humano é o uso excessivo da água nas dependências urbanas, rurais e industriais, também como meio de transporte e em atividades de lazer. Todas estas utilizações acabam por diminuir a qualidade e a disponibilidade da água, o que começa a ser sentido pela população humana de uma maneira geral.

Procurando minimizar este impacto no Brasil, duas leis (Lei Estadual № 7.663/91 e Lei Federal № 9.433/97), serviram para conferir legitimidade aos municípios que passaram a gerenciar os recursos hídricos por meio dos Comitês de Bacias Hidrográficas.

Para o adequado gerenciamento destas bacias, os Comitês baseiam-se em informações fornecidas por órgãos estaduais, tais como CETESB, SABESP e DAEE (no Estado de São Paulo).

Historicamente, desde Descartes no século XVII, o método científico consiste em separar o todo em pequenas partes e as estudar isoladamente (Capra, 1982). Em estudos ecológicos, o bioma terrestre é dividido em unidades, os ecossistemas que podem ser novamente divididos em unidades menores e assim por diante. Este particionamento do objeto de estudo resultou no surgimento de diversas disciplinas, como biogeoquímica, geologia e outras. Esta divisão de tarefas atuou como um facilitador para a geração de informações e compreensão das partes.

Apesar do grande volume de conhecimento adquirido, muitas perguntas permaneceram sem resposta e o método cartesiano mostrou-se limitado, já que, muitas vezes, os organismos necessitam de uma interpretação holística de seu funcionamento. Com base nesta percepção é que os estudos ecológicos em escala global ganharam força, 
com a Hipótese de Gaia (Lovelock, 1979; Thompson, 1987) como um dos ensaios mais notáveis.

Mais recentemente, a interligação entre os diversos sistemas da Terra tem sido retomada na literatura (Chase, 2000; Field et al., 1998; Schimel, 1995). Seguindo esta linha, estudos que integrem os cursos d'água e seus componentes (organismos e/ou variáveis químicas e físicas) a outros sistemas da bacia hidrográfica (solo e os diferentes usos a ele destinados) são bastante difundidos na literatura internacional (Collins \& Jenkins, 1996; Ekholm et al., 2000) e nacional (Ferraz et al., 2001; Silva \& Sacomani, 2001; Tomazelli, 2003).

De acordo com este pensamento, o estudo a ser aqui apresentado procurou integrar dados de algumas áreas do saber; ecologia e taxonomia de insetos aquáticos, técnicas de geoprocessamento, geoquímica da água e estatística. Apesar de dispor de diferentes disciplinas para sua execução, este estudo é parte de um projeto maior que objetivou avaliar várias bacias hidrográficas do Estado de São Paulo sob diversos aspectos científicos, procurando fornecer informações mais precisas sobre o funcionamento das bacias hidrográficas selecionadas, uma vez que as analisou sob um conceito holístico de seus funcionamentos.

O estudo aqui discutido utilizou quatro bacias hidrográficas do Estado de São Paulo como áreas de estudo; estas apresentam diferentes características quanto ao grau de degradação dos recursos hídricos, decorrentes de diferentes taxas de urbanização, industrialização e desenvolvimento (Tabela 1). Desta forma, pretendeu-se compreender como as atividades antrópicas, tais como diferentes graus de uso e ocupação do solo, influenciam a qualidade da água. Para tal, testou-se duas hipóteses; na primeira, verificou-se a influência do gradiente de ocupação humana na comunidade de insetos aquáticos. Enquanto que na segunda, verificou-se como a conversão do uso da terra, ou seja, mudança de mata ripária para pastagem influenciaria na comunidade de insetos aquáticos, em especial, Chironomidae (Diptera). 
Tabela 1. Informações sócio-econômicas das bacias hidrográficas estudadas

\begin{tabular}{lcccc}
\hline & Alto Paranapanema & Peixe & Aguapeí & S. J. Dourados \\
\hline $\begin{array}{l}\text { Área efetiva }\left(\mathrm{km}^{2}\right) \\
\begin{array}{l}\text { Número de } \\
\text { habitantes em 2000 }\end{array}\end{array}$ & 20.640 & 12.980 & 12.240 & 5.800 \\
$\begin{array}{l}\text { Densidade } \\
\text { demográfica } \\
\text { (hab/km }{ }^{2} \text { ) }\end{array}$ & 33 & $790 \times 10^{3}$ & $590 \times 10^{3}$ & $206 \times 10^{3}$ \\
$\begin{array}{l}\text { ton DBO } \\
\text { potencial/dia }\end{array}$ & 12 & 61 & 48 & 36 \\
$\begin{array}{l}\text { Volume de esgoto } \\
\text { tratado (\%) }\end{array}$ & 48 & 17 & 11 & 4 \\
$\begin{array}{l}\text { Número de } \\
\text { indústrias em 1999 }\end{array}$ & 1.211 & 29 & 26 & 63 \\
\hline
\end{tabular}

Fonte: Martinelli et al., 2002.

Desta forma, dois estudos foram conduzidos. No primeiro deles, as bacias hidrográficas são avaliadas em escala regional. Desta forma, verificou-se a influência de diferentes graus de ocupação das bacias na estrutura comunitária da entomofauna aquática. Informações sobre uso e ocupação do solo assim como declividade do terreno em escalas local (zona tampão de 50m - Lei № 7.511) e regional (sub-bacia a montante da área de coleta) foram levantadas; e também dados sobre variáveis químicas e físicas da água e da comunidade de insetos ali presente. A hipótese testada foi que as comunidades refletiriam o grau de degradação da bacia, apresentando uma fauna melhor estruturada, em termos de riqueza de táxons e número de representantes, nos locais menos impactados.

Grande é a literatura sobre o estudo da relação entre uso da terra e fauna aquática de outros países (de Billy et al., 2000; Fore et al., 1996; Guipponi \& Rosato, 1999; Hansen et al., 2001; Richards et al., 1996), com especial destaque aos da Nova Zelândia (Friberg \& Winterbourn, 1997; Melo et al., 2003; Niyogi et al., 2003; Townsend et al., 
1997). No Brasil, esta linha de pesquisa está em processo inicial e poucos são os trabalhos disponíveis, ressaltando a contribuição de Ometto et al. (2000 e 2004).

O segundo estudo desenvolvido buscou verificar a importância do corredor de mata ripária ao longo de rios na comunidade bentônica de insetos. Dois ambientes foram estabelecidos para coleta da entomofauna. Em um deles, a mata ripária estava preservada conforme determina a legislação ambiental (Lei № 7.511); no outro, a mata apresentava-se bastante devastada, até mesmo ausente. Neste caso, a hipótese proposta foi que a estrutura comunitária dos insetos aquáticos, com especial destaque para os Chironomidae (Diptera), sofreria alterações com a mudança da cobertura vegetal, ou seja, a retirada da mata ciliar para implantação de pastagem.

O papel da mata ripária na manutenção dos processos ecológicos em ambientes aquáticos é discutido por muitos autores (England \& Rosemond, 2004; Gergel et al., 2002; Inoue \& Nakagoshi, 2001; Maridet et al., 1998; Pinto et al., 2000; Young \& Huryn, 1999). Alguns estudos além de confirmarem esta importância da mata ciliar, estabelecem uma relação entre a mesma e a biota aquática (Prungle et al., 1988; Scrimgeour et al., 2000; Stewart et al., 2001). A exemplo da outra hipótese testada, há poucas pesquisas desta natureza conduzidas no estado de São Paulo, como aquele conduzido por Thorne \& Williams (1997).

Devido ao tamanho e profundidade dos rios e correnteza da água, a coleta de macroinvertebrados é extremamente difícil e poucos são os métodos de amostragem que se mostram eficientes nestes ambientes. Isto explica o reduzido número de trabalhos realizados nos mesmos, gerando uma deficiência no conhecimento destes sistemas lóticos e seus componentes. Apesar das limitações inerentes ao método, optou-se por coletar os insetos com cestos de substrato artificial.

O Brasil localiza-se em uma região com grande número de rios e a identidade e predição dos impactos do uso da terra nos hábitats intrínsecos destes sistemas são componentes essenciais no manejo dos mesmos; e as estratégias de conservação e restauração dependem deste conhecimento (Richards et al., 1996). Com este panorama em mente, procurou-se com o presente estudo, contribuir, mesmo que modestamente, na 
geração de informações que possam futuramente auxiliar na tomada de decisões pelos Comitês das bacias hidrográficas aqui estudadas. 


\section{REVISÃO DE LITERATURA}

A adoção da bacia hidrográfica como a menor unidade de um ecossistema a ser considerada para interesses humanos foi defendida por Odum (1983) e este conceito é atualmente adotado pelos órgãos de gestão dos recursos hídricos do Estado de São Paulo (DAEE, 2004). Para efeito ilustrativo, Odum considerava que para cada metro quadrado de água, uma área 20 vezes maior de terreno de drenagem seria necessária.

Como unidade de planejamento, as bacias hidrográficas possuem estreita relação com a população humana, nos aspectos econômicos, sociais e ambientais devido aos diversos usos aos quais os rios são destinados. Mais recentemente, com o crescimento desta população, o recurso aquático está superexplorado e este uso excessivo tem acarretado danos ao ecossistema pela retirada da mata ripária, alterações das margens e canal principal dos rios, pela poluição das águas, diminuição no volume de água e outros; todos estes fatores afetam direta ou indiretamente a vida dos organismos aquáticos (Barros, 2002).

Por bacia hidrográfica (bacia de drenagem ou bacia fluvial) entende-se uma área cujas águas superficiais e/ou subterrâneas escoam para um curso d’água; esta área é delimitada pelo divisor de águas (Pereira, 1995). Outra definição considera as bacias hidrográficas como regiões topográficas nas quais a água superficial drena para um ponto específico, lêntico ou lótico (Omernik \& Bailey, 1997). De acordo com estes autores, nos Estados Unidos o uso das bacias hidrográficas como unidade de estudo é decorrente do conhecimento de que a quantidade e a qualidade da água em um local é resultado da união das características da área topográfica a montante daquele local.

Devido à reconhecida importância das bacias hidrográficas, procurou-se avaliar os diversos aspectos ecológicos das mesmas e dos elementos que as compõem (Dumanski \& Pieri, 2000; Likens, 1984; Soulsby et al., 2001). 
É grande a preocupação por parte de pesquisadores e agências ambientais no manejo das bacias hidrográficas (Karr, 1994; 1995) e o uso dos cursos d'água para direcionar este manejo é bastante considerado (Hansen, 2001; Karr, 1998). Para tal, o estabelecimento de diretrizes e padrões mínimos necessários para avaliar a integridade e saúde de um rio são tentativas louváveis (Karr, 1999; Mihuc \& Feminella, 2001; Naiman \& Anderson, 1997).

Outro ponto a ser considerado nestes estudos é a escala de trabalho utilizada, pois esta irá influenciar de maneira decisiva nas conclusões obtidas (Cooper et al., 1998; Hewitt et al., 1998; Tickner et al., 2000).

Os variados usos da água e suas implicações diretas são facilmente observáveis em uma escala local; entretanto, em uma escala mais abrangente, as mudanças decorrentes de urbanização, desmatamentos, queimadas ou as mais diversas formas de plantio, mesmo que efetuadas a uma grande distância do curso d’água, acabam por influenciar na dinâmica do mesmo, já que estas provocarão alterações na quantidade de sedimento a ser carreado para dentro do rio, na taxa de sombreamento do rio e na introdução de insumos agrícolas que alterará o ciclo de vida dos organismos, com possível desaparecimento dos mais sensíveis.

Os sistemas aquáticos nos quais a água flui em uma única direção, denominados lóticos, são compostos não somente pelo canal do rio, mas também pela água subsuperficial que se movimenta na mesma direção da água superficial, a área de drenagem associada ao rio e a vegetação ripária (Naiman \& Bilby, 1998). Estes componentes são resultantes das interações transversais e longitudinais, havendo também um componente em sentido vertical que se associa com o meio hiporreico que é beneficiado pela humidade freática e é utilizado por muitas espécies que habitam os rios. Além destas três dimensões, há uma quarta, que é o tempo, cuja influência pode ser melhor observada nos locais de remanso, pois possibilita um certo grau de sedimentação, apesar do constante fluxo de água (del Rio \& Lastra, 1998).

Em relação ao fluxo de água, diferentes regiões podem ser encontradas ao longo do curso de um rio. Na zona de erosão, a velocidade da água é alta o suficiente para carregar pequenas partículas em suspensão. Neste trecho, o fundo do rio geralmente é 
formado por madeira, pedras e, algumas vezes, areia. Já nas regiões nas quais o fluxo de água torna-se menor, as zonas deposicionais, as partículas pequenas não são carreadas e depositam-se no fundo do rio. Estas zonas são mais comuns em rios de grande porte. (McCafferty, 1981). Devido à presença destas diferentes regiões em um rio, a compreensão sobre a estrutura e funcionamento das mesmas deve ser considerada no momento da amostragem.

Um marco no estudo da ecologia dos ambientes lóticos foi a publicação de "The ecology of running waters” (Hynes, 1972), cujo interesse pelo assunto foi realmente despertado.

Pereira (2002), afirma que as relações entre ambientes aquático e terrestre já eram conhecidas desde o início da Limnologia ${ }^{1}$, como pode ser visto no clássico trabalho de Thienemann (1913), que observou estreita relação entre a distribuição de zoobentos com a química e geologia da bacia de drenagem de lagos. Ao longo daquele século, outros autores afirmaram em seus estudos a interação entre ecossistemas fluviais e terrestres (Margalef, 1986; Payne, 1986).

A humanidade depende da água continental para diversas funções. Ela pode sustentar o uso da terra para produção sócio-econômica, ao mesmo tempo em que o mesmo uso da terra influencia nas características da água na superfície do solo e subsolo e no seu papel como carreador de solutos e sedimentos. Estes vínculos entre a água e o solo podem causar problemas em ambos sistemas; problemas estes que devem ser reconhecidos previamente para melhor gerenciamento dos recursos. Três tipos principais de atividades perturbadoras podem ser distinguidos, despejo de dejetos, manipulações relacionadas à biomassa e manipulações relacionadas aos sistemas aquáticos. Os problemas gerados são diferentes nas diferentes regiões hidroclimáticas (FAO, 1995).

O reconhecimento da importância da água não somente para a população humana como também para a manutenção do planeta foi uma pedra angular na decisão de preservar e manter este recurso natural em boas condições de qualidade.

\footnotetext{
${ }^{1}$ Estudo das relações funcionais e da produtividade das comunidades de água doce e o efeito nelas causado pelo seu ambiente físico, químico e biológico.
} 
A partir desta idéia, foi decisiva a definição do que seria a qualidade do recurso aquático e este conceito passou a ser considerado em função do seu destino ao invés de sua pureza. Conseqüentemente, a qualidade é boa ou ruim para um determinado uso. O gerenciamento da qualidade das águas exige formas de acompanhamento da alteração de suas variáveis indicadoras. Na medida do possível, este acompanhamento deve ser explicitado em números, através de critérios e padrões constantes em normas técnicas e legislações específicas.

O marco inicial da legislação de controle da qualidade das águas no Brasil foi o Código das Águas (Decreto № 24.643), que regulamentou o aproveitamento dos recursos hídricos e estabeleceu como proprietário o abastecimento público, reforçando a necessidade de manter-se sua qualidade.

Quase trinta anos depois foi redigida a primeira legislação federal específica sobre poluição das águas (Decreto Federal № 50.877); determinando a exigência de tratamento dos resíduos líquidos, sólidos ou gasosos, domiciliares ou industriais, antes do seu lançamento nos sistemas aquáticos. Também instituiu a classificação das águas de acordo com seus usos preponderantes, com respectivas taxas de poluição permissíveis. Pela primeira vez foi definido em lei federal o termo "poluição" aplicado às águas: qualquer alteração das propriedades físicas, químicas e biológicas das águas que possa implicar prejuízo à saúde, à segurança e ao bem-estar das populações e, ainda, comprometer sua utilização para fins agrícolas, industriais, comerciais, recreativos e, principalmente, a existência normal da fauna aquática.

A criação do Conselho Nacional de Controle da Poluição Ambiental (DecretoLei № 303 ) foi mais um passo importante no controle da qualidade das águas. Através deste Conselho, o conceito de poluição foi estendido aos ambientes aéreo e terrestre e introduziu-se a expressão “meio ambiente”. Segundo este Decreto-Lei, “denomina-se poluição qualquer alteração das propriedades físicas, químicas ou biológicas do meio ambiente (solo, água e ar) causadas por qualquer substância sólida, líquida, gasosa ou em qualquer estado da matéria que direta ou indiretamente seja nociva ou ofensiva à saúde, à segurança e ao bem-estar das populações; crie condições inadequadas para fins domésticos, agropecuários, industriais e outros, ou ocasione danos à fauna e à flora”. 
A partir da década de 60, conceitos como "meio ambiente" e "impacto ambiental” começaram a fazer parte da linguagem jurídica; entretanto, sua consolidação foi na década de 70, com a criação da Secretaria Especial de Meio Ambiente (SEMA) do Ministério do Interior (Decreto-Lei № ${ }^{0}$ 73.030).

Com isto, as águas passaram a ser analisadas dentro de um panorama mais abrangente, perdendo sentido a discussão apenas em termos da expressão “água potável” empregada pelo Código Penal de 1940, como sinônimo de águas naturais. A água passou a ser protegida não somente por sua potabilidade atual ou potencial, mas sim como elemento de um ecossistema a ser preservado na sua totalidade (Comitê da Bacia Hidrográfica do Pontal do Paranapanema, 1999).

Para a avaliação da qualidade da água, uma ampla gama de variáveis podem ser utilizadas, cujos valores indicam diferentes respostas do ambiente. Em relação às variáveis químicas e físicas mais comuns, pode-se encontrar (Salomão, 2004):

Temperatura - variações de temperatura são parte do regime climatológico normal e corpos d'água naturais apresentam variações sazonais e diurnas com estratificação vertical. A temperatura superficial é influenciada por fatores tais como latitude, altitude, estação do ano, período do dia, fluxo da água e profundidade do canal.

A elevação da temperatura em um corpo d'água geralmente é provocada por despejos industriais e usinas termoelétricas. O desmatamento também é um fator que auxilia no aumento de temperatura da água, por diminuir o sombreamento.

A temperatura desempenha um papel importante como controlador do meio aquático, condicionando as influências de uma série de variáveis físico-químicas. Em geral, à medida que a temperatura aumenta de zero a $30^{\circ} \mathrm{C}$, a viscosidade, tensão superficial, compressibilidade, calor específico, constante de ionização e calor latente de vaporização diminuem, enquanto a condutividade térmica e a pressão de vapor aumentam as solubilidades com a elevação da temperatura. Organismos aquáticos possuem limites superior e inferior de tolerância térmica, temperaturas ótimas de crescimento, temperatura preferida em gradientes térmicos e limitações de temperatura para migração, desova e incubação do ovo. Também tende a diminuir a riqueza da comunidade. Além disso, temperatura elevada pode levar à desnaturação de proteínas. 
Potencial hidrogeniônico $(\mathrm{pH})$ - alterações bruscas do $\mathrm{pH}$ podem acarretar o desaparecimento de organismos presentes no ambiente aquático. Valores fora das faixas recomendadas podem alterar o sabor da água e contribuir para a corrosão do seu sistema de distribuição ocorrendo com isso, uma possível extração de ferro, cobre, chumbo, zinco e cádmio, além de dificultar a descontaminação das águas.

Oxigênio dissolvido (OD) - uma adequada provisão de oxigênio dissolvido é essencial para a manutenção de processos de autodepuração em sistemas aquáticos naturais e estações de tratamento de esgotos. Através de medição do teor de oxigênio dissolvido, os efeitos de resíduos oxidáveis sobre águas receptoras e a eficiência do tratamento dos esgotos, durante a oxidação bioquímica, podem ser avaliados. Os níveis de oxigênio dissolvido também indicam a capacidade que um corpo d’água natural possui de manter a vida aquática.

Demanda bioquímica de oxigênio (DBO) - é a quantidade de oxigênio necessária para oxidar a matéria orgânica por decomposição microbiana aeróbia para uma forma inorgânica estável. Normalmente, é considerada como a quantidade de oxigênio consumido durante um determinado período de tempo (em geral, cinco dias), numa temperatura de incubação de $20^{\circ} \mathrm{C}$. É freqüentemente usada e referida como $\mathrm{DBO}_{5,20}$.

Os maiores aumentos em termos de DBO em um corpo d’água são provocados por dejetos de origem predominantemente orgânica. A presença de um alto teor de matéria orgânica pode induzir à completa eliminação do oxigênio na água, provocando o desaparecimento de peixes e outras formas de vida aquática.

Um elevado valor de DBO pode indicar um aumento da microflora presente e interferir no equilíbrio da sobrevivência da biota, além de produzir sabores e odores desagradáveis e, ainda, pode obstruir os filtros de areia utilizados nas estações de tratamento de água.

Nitrogênio total (amônia, nitrato, nitrito e nitrogênio orgânico) - constituinte essencial da proteína em todos os organismos vivos e está presente em muitos depósitos minerais na forma de nitrato. O nitrogênio na matéria orgânica sofre trocas do complexo protéico de aminoácidos para amônia, nitrito e nitrato. 
A concentração total de nitrogênio é altamente importante, considerando-se os aspectos tópicos do corpo d’água. Em grandes quantidades o nitrogênio contribui como causa da metaemoglobinemia infantil.

Fosfato total - altas concentrações estão associadas a eutrofização da água, proporcionando o desenvolvimento de algas e plantas aquáticas principalmente em locais de águas paradas.

Turbidez - alta turbidez reduz a fotossíntese da vegetação enraizada, submersa e algas. Esse desenvolvimento reduzido das plantas pode suprimir a produtividade de peixes e influenciar no ciclo de vida da entomofauna. Além disso, afeta adversamente os usos doméstico, industrial e recreacional da água.

Condutividade - é uma expressão numérica da capacidade da água em conduzir a corrente elétrica. A condutividade depende das concentrações iônicas e da temperatura.

A condutância específica fornece uma boa indicação das modificações na composição de uma água, especialmente na sua concentração mineral, mas não fornece nenhuma indicação das quantidades relativas dos vários componentes. À medida que mais sólidos dissolvidos são adicionados, a condutividade específica da água aumenta. Altos valores podem indicar características corrosivas da água.

Turbulência - gerada pela corrente, causa distúrbios na mobilidade dos organismos e suspensão de partículas conseqüentemente, diminui a visibilidade, afetando as relações intra e interespecíficas.

Segundo pesquisa desenvolvida por Fagundes (2002), as alterações nos ambientes da Terra têm resultado em conseqüências desastrosas, em muitas ocasiões, causando piora na qualidade de vida das populações humanas. Exemplo disto é a proliferação de doenças já existentes, o ressurgimento de algumas já erradicadas e o aparecimento de novas doenças para a espécie humana. Verificou-se, portanto, que mudanças no equilíbrio da natureza podem favorecer alguns patógenos, causando epidemias. Em face disto, o homem tem descoberto que o custo para restabelecer a integridade dos recursos naturais e da saúde da população pode ser muito elevado.

Para a recuperação destes recursos, diversos fatores são importantes, sendo que o grau de interferência é variável. Um destes fatores são as matas ripárias (ou ciliares). O 
termo "riparius" (do latim) que significa “de ou pertencente à margem do rio”. No Cerrado, a mata ciliar é definida como a vegetação florestal que margeia os rios de médio e grande porte, enquanto que para aqueles de pequeno porte (riachos e córregos), a terminologia mais empregada é mata de galeria, em função dos corredores formados sobre os cursos d’água (Ribeiro et al., 1999).

As áreas ripárias são um mosaico diverso de relevo, comunidades e ambientes dentro de uma paisagem maior. Por exemplo, elas servem para estabilizar a organização, diversidade e dinâmica das comunidades associadas aos ecossistemas aquáticos. Freqüentemente, é difícil delinear precisamente a extensão espacial da zona ripária porque sua heterogeneidade física é expressa através de estratégias de história de vida das plantas e padrões de sucessão, interagindo no ambiente no qual se encontram. A mata ripária estende-se lateralmente ao canal principal, incluindo a várzea ativa e os terraços (Naiman \& Bilby, 1998).

Loureiro (1998), enfatiza que uma mata ciliar caracteriza uma grande diversidade de formações vegetais e que a ocupação histórica das propriedades rurais exercem pressão para o desmatamento nestas áreas, que está ligada à expansão agrícola, às hidrelétricas entre outros.

Estas matas ciliares são de grande importância pelos múltiplos benefícios que causam, representados pela estabilização das margens; tamponamento e filtragem, participando do ciclo de nutrientes, evitando o carreamento de sedimentos para o sistema aquático; interceptação e absorção da radiação solar, contribuindo para a estabilização térmica dos pequenos cursos d’água; proporcionando abrigo e/ou alimento para peixes, aves e grande número de mamíferos; representarem uma valiosa área de preservação e conservação de recursos naturais vegetais (Aguiar et al., 2002; Marinho Filho \& Reis, 1989; Rodrigues et al., 1992).

Ainda, as matas ciliares constituem-se em fornecedores de alimentos para um grande número de espécies, como sementes para peixes, aves, roedores e outros animais. Também fornecem insumos para polinizadores e outros de importância para a natureza. Estes fatores tornam a mata ciliar um importante elo de inter-relacionamento com diversos elementos presentes no ambiente (Ribeiro et al., 1999). 
Para Bierregaard et al. (1992), estas matas criam condições ideiais para a sobrevivência e manutenção do fluxo gênico entre populações de espécies animais que habitam as faixas ciliares ou mesmo fragmentos florestais maiores por elas conectados.

Em estudo realizado por Pinto et al. (2000), os autores verificaram que a mata ripária produziu alta biomassa de serrapilheira (1,2ton/ha/ano), superando o citado para as matas alagáveis ou não, sendo que os maiores valores da biomassa total foram liberados pelas folhas durante a estação seca e pelos ramos na estação úmida. A matéria orgânica nos sistemas aquáticos é item primordial para a manutenção da vida nestes ambientes. Em face disto, o estudo acima ilustra o tamanho do valor da mata ripária para os ambientes aquáticos e sua biota.

Além dos benefícios diretos, existem outros, indiretos, representados pela valorização da paisagem, possibilidades da realização de inúmeros projetos de lazer e educação ambiental que necessitam de espaços florestados no entorno dos cursos de água (Leitão Filho, 1994).

Por todos os benefícios fornecidos pela presença de tal vegetação, áreas de preservação permanente ao longo dos rios foram estabelecidas por Lei ( $\mathrm{N}^{\mathrm{o}}$ 7.511), estabelecendo-se a preservação de uma faixa marginal ao longo dos corpos e cursos d’água, dependendo da largura do mesmo:

- Rios com menos de dez metros de largura, a área de preservação permanente tem largura de 30m, no mínimo;

- Rios que medem entre dez e 50m, área de preservação deve ter, no mínimo, 50m de largura;

- $100 m$ de largura de área de preservação, no mínimo, para rios que meçam entre 50m e 100m de largura;

- $150 \mathrm{~m}$, no mínimo, para rios que meçam ente $100 \mathrm{~m}$ e $200 \mathrm{~m}$ de largura;

- Uma largura igual à distância entre as margens para os cursos d’água com largura superior a $200 \mathrm{~m}$.

Muitos são os esforços para manter a integridade dos ambientes aquáticos, porém estas medidas foram tomadas tardiamente. Historicamente, as florestas eram vistas como algo ruim, o progresso de um local estava associado ao desmatamento. Esta prática, 
principalmente ao longo do século XIX, eliminou a entrada de grandes pedaços de madeira nos canais dos rios, resultando em diminuição na complexidade estrutural dos hábitats aquáticos ribeirinhos (Loeb \& Spacie, 1990) e conseqüentemente, afetou os organismos que ali vivem. A ausência destas matas gera uma dificuldade de infiltração das águas no solo, que, com a ocorrência de enxurradas, ocorre o carreamento de partículas iniciando processos erosivos (Lange, 1997).

Um córrego saudável possui uma grande variedade de espécimes e uma população numericamente moderada da maioria dos táxons. A diversidade é uma característica chave; sua diminuição pode indicar perda de saúde, e uma ou poucas espécies poderão ter uma grande população prejudicando outros táxons. Quando a população como um todo torna-se menor e somente poucas formas estão presentes, provavelmente há poluição orgânica e contaminação tóxica do ambiente (Dunne \& Leopold, 1978).

A classe Insecta é pertencente ao filo Artropoda; devido à grande complexidade morfológica dos integrantes deste filo, poucas são as características básicas que o descrevem. Os insetos distinguem-se dos outros artrópodes por apresentarem três pares de apêndices articulados e, comumente, dois pares de asas ligadas à região torácica. Além disso, a cabeça exibe, tipicamente, um par de antenas e outro de olhos compostos. Um sistema traqueal serve às trocas gasosas e os gonodutos abrem-se na extremidade posterior do abdômen (Barnes, 1984).

Numericamente, é o grupo mais expressivo de todo reino animal, havendo mais de 750 mil espécies descritas. Entretanto, como a fauna da região Neotropical ainda está em processo de catalogação e descrição de espécies, as estimativas variam bastante, uma vez que se acredita que é a região do globo com maior riqueza de táxons de insetos (Armitage et al., 1995).

Podem ser encontrados ocupando todos os tipos de hábitats do planeta, desde desertos, mares, excrementos e regiões geladas (Cheng \& Collins, 1980; Convey \& Block, 1996; Menu-Marques, 2002; Sugg et al., 1983). Várias adaptações foram desenvolvidas para a sobrevivência nestes ambientes inóspitos, apresentando os mais 
diferentes nichos ecológicos. Esta capacidade de adaptação e sobrevivência é um dos feitos mais extraordinários deste grupo.

O interesse do homem pelo ambiente ao seu redor e os organismos que o compõem, data da pré-história, fato observado pelos desenhos encontrados por arqueólogos, ao estudarem algumas cavernas que outrora foram habitadas pelos nossos ancestrais (McCafferty, 1981). Certamente, os primeiros insetos a serem observados foram aqueles capazes de importunar a vida humana, picando ou formando enxames para proteção da população, como fazem as abelhas.

Após esse primeiro interesse pelos insetos, vieram os filósofos gregos que, com seus estudos sobre a natureza, fizeram apontamentos sobre vários grupos animais, inclusive os insetos. Naquela época, o principal interesse pelos insetos estava relacionado à prática da pesca, uma vez que, alguns táxons consistiam em um item alimentar bastante apreciado pelos peixes. Posteriormente, somente no século XVI é que o interesse pela classe ressurgiu, auxiliado pela invenção da microscopia e pelas coleções trazidas nas viagens de além-mar (McCafferty, 1981).

Nesta época, não havia um sistema único para catalogar os organismos, o que consistia em verdadeira confusão. Linnaeus, em 1758, com a décima edição de seu livro, Systema Naturae, propôs uma sistemática universal para os diversos grupos de seres vivos conhecidos até o momento. Porém, na questão dos insetos, Fabricius foi quem se destacou como o primeiro grande taxonomista.

Um grande reforço para ampliar o estudo dos insetos deveu-se aos surtos de doenças tropicais transmitidas por insetos vetores. Grandes esforços foram despendidos no início do século XIX na geração de informações que auxiliassem no controle, ou até mesmo na erradicação, de doenças como malária e febre amarela. Oswaldo Cruz, Emílio Ribas e Carlos Chagas são nomes notáveis que contribuíram nestas campanhas (www.oc.fiocruz.br).

A preocupação por parte dos fazendeiros com os constantes ataques sofridos pelas lavouras brasileiras por saúvas, gafanhotos, cigarrinhas e outros insetos, fez com que o estudo destes animais e suas relações com a agricultura fosse impulsionado nas escolas e institutos agrícolas. O conhecimento do ciclo de vida destas pragas da lavoura 
foi um passo em direção ao estudo das relações ecológicas dos insetos de uma forma geral. Nessa época, a ecologia entomológica começava a tomar corpo como ciência; juntamente com a conscientização de que uma melhor qualidade de vida estava ligada não somente à saúde, condições alimentares e de moradia, mas um papel primordial foi atribuído à natureza.

No final do século XIX, aparecem os primeiros trabalhos demonstrando as funções dos insetos no ambiente aquático, como por exemplo "The lake as a microcosm” (Forbes, 1887), um clássico da ecologia aquática.

Grupos de insetos tiveram estruturas fisiológicas, morfológicas e também respostas comportamentais adaptadas para o sucesso da vida na água. A respiração constitui uma das adaptações mais complexas e diversas, além de sua indiscutível importância para ocupação do hábitat. Os besouros desenvolveram um mecanismo denominado plastro que lhes permite tomar uma bolha de ar na interface água-ar e, a partir daí, respirar embaixo da água. Outra adaptação respiratória é a presença de hemoglobina em larvas de alguns Chironomidae (Diptera) e Anisopinae (Hemiptera) (Ward, 1992).

A forma do corpo também sofreu modificações para garantir a sobrevivência na água; os organismos tiveram um achatamento dorso-ventral e, em muitos casos, possuem forma de gota d’água, com a cabeça como a extremidade mais fina. Esta configuração facilita que a corrente de água passe pelo organismo, diminuindo o atrito e, conseqüentemente, torna mais fácil a aderência a substratos, diminuindo o efeito da correnteza (Resh \& Rosemberg, 1984).

Um exemplo de adaptação comportamental é a construção de tubos utilizando gravetos ou grãos de areia po algumas espécies de Trichoptera. Quando a água passa pelos tubos, a matéria orgânica em suspensão fica aderida às paredes do mesmo e as larvas raspam as paredes retirando essa matéria orgânica, alimentando-se (McCafferty, 1981). Muitos outros exemplos de adaptações à vida aquática são apresentados em livros de entomologia aquática. 
As ordens de insetos aquáticos são facilmente identificadas, uma breve coletânea das principais características morfológicas e informações adicionais sobre os grupos é dada a seguir (McCafferty, op. cit.; del Rio \& Lastra, 1998).

Ephemeroptera - Abdômen termina em três filamentos, pernas torácicas não são fundidas ao corpo; asas ou protótipos de asas estão presentes. Se o abdômen termina em menor número de filamentos caudais, as asas são pequenas. Brânquias laterais de diversos formatos são encontradas no abdômen. São detritívoros e fitófagos.

Plecoptera - Muito parecidos com os efemerópteros, porém possuem apenas dois cercos caudais, sem brânquias abdominais laterais; porém se forem presentes, são restritas aos primeiros segmentos abdominais. Asas são reduzidas e os três pares de pernas torácicas não são fundidos ao corpo.

Odonata - São as libélulas. As formas imaturas possuem grandes mandíbulas que são modificadas em forma de máscara e cobrem todas as outras peças bucais quando em repouso. Abdômen possui brânquias terminais internas (Anisoptera) ou externas (Zygoptera). Asas ou protótipos de asas estão presentes. Apresentam três pares de pernas segmentadas não fundidas ao corpo.

Hemiptera - Boca em forma de bico que se projeta para baixo da cabeça; olhos compostos. Asas ausentes; tórax com três pares de pernas segmentadas (pernas podem ser pequenas e fundidas ao corpo).

Orthoptera - Pernas traseiras são alargadas e modificadas para o salto e as dianteiras são modificadas para escavar, em alguns táxons. Abdômen termina ou não em caudas. Asas ou protótipos de asas são presentes.

Coleoptera - São os besouros. A diversidade de formas corpóreas é alta entre as formas imaturas deste grupo. Terminação abdominal diversa, porém nunca em um filamento alongado e único e nunca com um par de pseudópodos com apenas um gancho. 
Abdômen pode possuir ou não filamentos laterais bastante desenvolvidos. Asas ausentes; tórax com três pares de pernas segmentadas (pernas podem ser pequenas e fundidas ao corpo). Quando os pseudópodos são ausentes, o corpo é largo, mole e curvado ou possui placas dorsais esclerotizadas nos segmentos torácicos e no oitavo segmento abdominal. A cabeça é distinta e bem desenvolvida e o tórax não possui pernas.

Megaloptera - Abdômen terminando em um filamento longo, único ou em um par de pseudópodos, cada um com um par de ganchos. Abdômen com filamentos laterais bastante desenvolvidos. Asas ausentes, tórax com três pares de pernas segmentadas (pernas podem ser pequenas e fundidas ao corpo). São predadores.

Trichoptera - Abdômen termina em um par de pseudópodos, longos ou curtos (algumas vezes fundidos em uma única placa), com um único gancho terminal. Asas ausentes; tórax com três pares de pernas segmentadas (pernas podem ser pequenas e fundidas ao corpo). As larvas se caracterizam por possuírem um par de pseudópodos anais e fabricam seda para construção de redes e tubos, para moradia e/ou captação de alimento. Estes tubos podem ser feitos de grãos de areia, pedaços de madeira de diversos tamanhos ou folhas, atados pelos fios de seda.

Neuroptera - A boca possui estruturas compridas e finas que se projetam para frente; quando estão unidas, formam um tubo sugador. Asas ausentes; tórax com três pares de pernas segmentadas (pernas podem ser pequenas e fundidas ao corpo).

Lepidoptera - Abdômen apresenta pares de pseudópodos que terminam numa série de pequenos ganchos. Asas ausentes; tórax com três pares de pernas segmentadas (pernas podem ser pequenas e fundidas ao corpo). São as borboletas e mariposas. Há apenas uma família (Pyralidae) de Lepidoptera com representantes de vida aquática. 
Diptera - Cabeça indistinta ou parcialmente presente; se for distinta e bem desenvolvida, os pseudópodos são geralmente presentes no tórax ou final do abdômen ou ambos; se os pseudópodos são ausentes, então cerdas ou processos bastante distintos estão presentes no final do abdômen. O corpo é bem fino, altamente esclerotizado ou dividido em várias regiões distintas. Tudo isto se o tórax não apresentar três pares de pernas segmentadas. Por outro lado, se as pernas estiverem presentes, asas ou protótipos de asas são presentes, as pernas são fundidas ao corpo e há apenas um par de asas. É uma das maiores e mais diversas ordens. Aqui, vale a pena ressaltar a família Chironomidae que é considerada a mais importante nos sistemas aquáticos pela sua riqueza faunística, pelo amplo espectro ecológico e pela alta densidade de algumas espécies.

Os quironomídeos apresentam um ciclo de vida relativamente curto e a grande quantidade de larvas confere significância energética ecológica ao grupo (como consumidor e como presa) (Johnson \& Pejler, 1987) e os recursos ecológicos são compartilhados por um grande número de espécies, garantindo a estabilidade biótica dos sistemas aquáticos (Merritt \& Cummins, 1984).

Com uma diversidade ecológica bastante abrangente (Ali, 1980); o hábitat aquático é o mais comumente utilizado para o desenvolvimento dos estágios imaturos (Ueno et al., 1993), incluindo desde lagos, lagoas, pântanos, rios, córregos, nascentes até águas oceânicas (Palmén \& Lindeberg, 1959). Muitas espécies são comuns no ambiente terrestre, outras habitam locais com condições ambientais extremas, como fontes termais, fitotelmas etc.; também são encontradas em solos úmidos e vegetação morta em decomposição (Armitage et al., 1995; Oliver, 1971).

Sua capacidade de ocupar os mais variados ambientes deve-se, em grande parte, às suas adaptações aos extremos (Convey \& Block, 1996), entre essas pode-se citar a tolerância de algumas espécies à baixa concentração de oxigênio na água, como é o caso de várias espécies do gênero Chironomus; tolerância à desidratação e altas variações de temperatura (Polypedilum vanderplanki) (Armitage et al., 1995); sobrevivência em ambientes com grandes variações de pH (Pinder, 1986).

Alguns grupos brasileiros de renome têm tradição na pesquisa desta família; muitos são os trabalhos sobre taxonomia (Messias, 2000; Oliveira, 2000; Sanseverino \& 
Wiedenbrug, 2000), entretanto, pelo elevado número de hábitats peculiares presentes no Brasil, ainda há muito por identificar e descrever. Mesmo com a limitação imposta pelo não conhecimento de muitas espécies, estudos ecológicos que mencionam o grupo são conduzidos em todo o país (Galdean et al., 2001; Sonoda et al., 1997; Sonoda \& Trivinho-Strixino, 2000).

De uma maneira geral, os insetos aquáticos distribuem-se na coluna d’água e podem ocupar os mais variados hábitats ali disponíveis. Aqueles denominados bentônicos, assim o são por habitarem o sedimento.

Com o avanço das pesquisas ecológicas e o estabelecimento do papel de cada organismo no funcionamento do ambiente, juntamente à crescente urbanização e avanços tecnológicos que resultam em última instância em diferentes graus de degradação ambiental, verificou-se que alguns organismos são mais sensíveis que outros e, por isso mesmo, mais suscetíveis às mudanças. Desaparecimento de certos táxons, alterações morfológicas, mudanças no período de vida são exemplos de respostas que os organismos exibem face à diminuição na taxa de oxigênio dissolvido na água, eutrofização de corpos d'água dentre uma gama de alterações que os ambientes aquático e terrestre vêm sofrendo nos últimos séculos.

Estes seres que se situam nos extremos fisiológicos, ou seja, tolerantes ou sensíveis às mudanças ambientais, têm sido usados como indicadores biológicos da qualidade ambiental (Nipper, 1990). No ambiente aquático, os insetos são muito usados como indicadores da qualidade da água por terem um tempo de ciclo de vida intermediário em relação às bactérias e aos peixes e terem pouca mobilidade física, quando comparados com estes últimos (Fagundes \& Shimizu, 1997; Roque et al., 2000).

Além do mais, nos últimos anos, têm-se demonstrado que o uso da biota tem uma resposta muito mais confiável que a análise de variáveis químicas (Hall et al., 2003; Michailova et al., 2003), pois estas somente são detectadas se a coleta de água for feita no mesmo instante que a entrada de material contaminante, uma vez que podem ser facilmente carreados, diluindo-se no sistema. Já os organismos, devido às interações intra e interespecíficas e também pelo simples fato de viverem neste ambiente, tendem a 
acumular substâncias nocivas que podem gerar diversos níveis de manifestações, desde o aparecimento de mal-formações até efeitos letais, com a extinção de alguns táxons.

A avaliação e o monitoramento do ambiente através de organismos isolados ou em comunidade, mais comumente conhecidos como biomonitoramento, podem ser qualitativos, semiquantitativos ou quantitativos. É uma técnica muito valiosa cujo uso está aumentando e ganhando importância nos programas de determinação da qualidade da água (Brandimarte et al., 1999).

A análise ambiental envolve o uso de espécies ou comunidades indicadoras. Geralmente, utiliza-se macroinvertebrados bentônicos, peixes ou algas. Certas plantas aquáticas também podem ser usadas como indicadoras de poluentes, incluindo enriquecimento orgânico (Batiuk et al., 1992; Phillips \& Rainbow, 1993). Há vantagens e desvantagens no uso de cada um dos indicadores, sendo os macroinvertebrados muito utilizados (Fonseca-Gessner \& Guereschi, 2000; Nelson, 2000; Pavluk et al., 2000; Pinel-Alloul et al., 1996; Rosenberg \& Resh, 1993).

As vantagens na utilização deste grupo devem-se a vários fatores:

- Os macroinvertebrados bentônicos são encontrados na maioria dos hábitats aquáticos;

- Há um grande número de espécies e diferentes estresses produzem diferentes comunidades;

- Córregos de pequena ordem freqüentemente não suportam peixes, porém suportam ampla comunidade de macroinvertebrados;

- Os macroinvertebrados geralmente possuem mobilidade limitada, portanto, são indicadores de condições ambientais locais;

- São acumuladores de substâncias tóxicas, por isto, estas podem ser detectadas em seus tecidos quando não o são na água;

- Um biólogo experiente na identificação dos macroinvertebrados é capaz de determinar de modo relativamente rápido o quanto um ambiente está degradado, identificando mudanças na comunidade;

- São suficientemente pequenos para serem facilmente coletados e identificados; 
- A amostragem em geral é fácil, necessita poucas pessoas e equipamento, e também não afeta outros organismos;

- Constituem a principal fonte de alimento de importantes peixes comerciais e recreacionais. Um impacto nesta comunidade gera um impacto na cadeia alimentar.

Apesar de haver muitas vantagens em se trabalhar com os macroinvertebrados, há importantes desvantagens que devem ser lembradas:

- Variações sazonais podem impedir comparações de amostras feitas em diferentes estações;

- A deriva pode trazer grupos cuja ocorrência não é comum para determinado lugar. O conhecimento deste comportamento em certas espécies pode minimizar esta desvantagem;

- Alguns grupos são difíceis de identificar em nível específico.

Esta combinação de características garante que os insetos bentônicos respondam às condições ambientais naturais ou antropogênicas, que física ou quimicamente alteram o sedimento de fundo; integrem efeitos de um período aproximadamente anual e caracterizem efeitos sobre uma área espacial relativamente pequena em contraste aos peixes, que podem percorrer longas distâncias. Estes fatores fazem destes organismos um bom instrumento para analisar a qualidade da água específica do local e comparar os padrões espaciais da qualidade da água em vários locais, e para integrar efeitos que representam entre seis meses a um ano de exposição local. Também são particularmente importantes no monitoramento dos efeitos cumulativos de um local, devido às condições em toda região a montante (Hynes, 1975).

A distribuição das espécies responde às influências naturais e antropogênicas. Mudanças naturais nas condições químicas e físicas ocorrem ao longo do eixo longitudinal do rio, alternando variáveis ambientais (condições ripárias, regimes termais, padrões de descarga, penetração da luz, gradientes do canal, condições do sedimento, química da água e sedimento), todas estas ocasionando mudanças na comunidade bentônica. Além disso, cada local ao longo do rio há uma variedade de hábitats, como corredeiras, piscinas, bancos, canais abandonados que diferem quanto ao tipo e 
estabilidade do substrato, velocidade da corrente e profundidade. Cada local tem suas condições naturais peculiares que determinam a capacidade de um organismo viver em um hábitat particular de um ponto específico do rio.

Esses padrões de distribuição de espécies são afetados por fatores que alteram a região (por exemplo, incêndios, tremores de terra, agricultura, erupções vulcânicas e urbanização), modificando as condições hidrológicas (mudanças na evapotranspiração e escoamento superficial ou construção de represas e irrigação), alterando hábitats (sedimentação, tempestades) ou adicionando compostos químicos que são tóxicos ou que elevam o teor de nutrientes ou carga orgânica.

Da mesma forma que as alterações nas variáveis químicas e físicas da água representam seu estado de preservação e reafirmando os conceitos citados anteriormente sobre a utilização dos organismos aquáticos para a avaliação da água, segue uma explicação mais detalhada de como suas presença/ausência no ambiente são interpretadas (Klemm et al., 1990; Plafkin et al., 1993; Rosenberg \& Resh, 1993).

- Enriquecimento de nutrientes - aumenta a razão de vermes aquáticos (Oligochaeta) para insetos aquáticos; aumenta a taxa de Chironomidae para outros insetos aquáticos; aumenta a quantidade de Ephemeroptera e Chironomidae;

- Baixo oxigênio dissolvido - aumenta a razão Oligochaeta: insetos aquáticos; aumenta a razão Chironomidae: insetos aquáticos;

- Contaminação por metais pesados - aumenta a razão Oligochaeta: insetos aquáticos; aumenta a razão Chironomidae: insetos aquáticos; aumenta a abundância de Coleoptera e Hemiptera; aumenta a razão predadores: (herbívoros e detritívoros);

- Sedimentação - diminui a quantidade de Ephemeroptera e Chironomidae;

- Baixo pH - perda de Ephemeroptera e Chironomidae (Adamus \& Brandt, 1990).

Em relação à composição da comunidade, suas categorias funcionais de alimentação e uso de índices, as respostas comportamentais às alterações ambientais são: 
- Número de táxons - tende a diminuir com a diminuição da qualidade da água. Deve-se atentar para o fato de que a dificuldade de identificação leva a resultados subestimados;

- Número de indivíduos - poluentes podem levar ao aumento (no caso de nutrientes) ou diminuição (pesticidas) do número ou biomassa;

- Razão de indivíduos numericamente dominantes para o total do número de indivíduos. A dominância de poucos táxons indica stress ou condições que suportam certos táxons, tais como, enriquecimento de nutrientes, baixo oxigênio dissolvido e contaminantes tóxicos;

- Razão raspadores:total - os raspadores são sensíveis às substâncias tóxicas e mudanças no hábitat;

- Razão picadores:coletores - os picadores indicam disponibilidade de recursos alimentares. A dominância de coletores indica enriquecimento orgânico. Declínio na quantidade de coletores-filtradores é indicativo da presença de contaminantes tóxicos.

Para a geração de informações sobre uso e cobertura do solo é imprescindível a utilização de sistemas de informações geográficas e de técnicas de sensoriamento remoto. O sistema de informações geográficas (SIG) dispõe de um conjunto de ferramentas e operações que permitem a integração e análise de dados, de maneira a transformá-los em informações úteis para tomada de decisões.

Por “sensoriamento remoto” entende-se o agrupamento de métodos que empregam energia eletromagnética (como luz, calor e ondas de rádio) como meio de detectar e medir características do alvo. Esta definição exclui verificações elétricas, magnéticas e gravitacionais para medir campos de força. Análises magnéticas e radioativas são freqüentemente feitas com aviões, mas são consideradas análises de natureza geofísica ao invés de sensoriamento remoto. Garcia (1982), definiu o sensoriamento remoto como a detecção da natureza de um objeto sem que haja contato físico, em que aviões e satélites são as plataformas mais comuns.

A história do sensoriamento remoto pode ser dividida em duas partes, a primeira, entre 1860 e 1960, consiste na utilização de fotografias aéreas e a segunda, após 1960, 
caracterizado pela multiplicidade de sistemas sensores. A complexidade das atuais técnicas de sensoriamento remoto faz com que um maior número de pessoas de diferentes áreas cada vez mais participem do processo de transformação da energia registrada; sendo fruto de um esforço multidisciplinar (Novo, 1992).

Com relação ao SIG, este engloba programas, procedimentos e módulos (ou subsistemas) integrados e projetados para dar suporte ao armazenamento, processamento, análise, modelagem e exibição de dados e/ou informações espacialmente referenciadas, constituídas numa única base de dados (Lamparelli et al., 2001).

O SIG normalmente integra diversos outros sistemas (processamento digital de imagens, análise estatística, análise espacial, digitalização etc.) para ser capaz de realizar estas operações e ainda dispor de entrada e saída de dados em diversos formatos, tendo como ponto central um banco de dados.

O SIG apresenta quatro grupos de funções principais:

1. Entrada de dados - sistema de processamento digital de imagens, digitalização de mapas, sistema de posicionamento global, dados tabulares (planilhas eletrônicas) e dados estatísticos;

2. Armazenamento de dados - banco de dados espacial (mapas digitais) e banco de dados de atributos (alfanuméricos);

3. Análise de dados - sistema de análise geográfica (operações algébricas), sistema de análise estatística e sistema de gerenciamento de banco de dados;

4. Saída de dados - sistema de exibição cartográfica (saída de mapas para a tela, impressora e arquivos digitais).

A unidade básica que forma uma imagem é denominada "pixel” (do inglês, picture element) e seu tamanho varia de acordo com o sensor selecionado para fazer a imagem (Silva, 2003).

Erros, ruídos ou distorção geométrica podem ocorrer durante a varredura, transmissão ou gravação dos dados. O processo de restauração reconhece e compensa estas falhas, procurando formar uma imagem o mais próximo da cena original. Após a restauração, procede-se a melhora no impacto visual que a imagem produz no observador, aumentando o conteúdo da informação. 
O último passo é a extração de informações para utilizar a capacidade de tomada de decisões do computador para reconhecer e classificar pixels baseando-se nas assinaturas espectrais.

Um dos aspectos fundamentais de aplicação de sensoriamento remoto ao mapeamento do uso da terra é a definição do sistema de classificação. A função do sistema de classificação é fornecer um quadro de referência para a organização e hierarquização da informação. Não existe um sistema único e aplicável a qualquer circunstância. Entretanto, qualquer que seja o sistema, é importante que ele permita a incorporação hierárquica de informação, à medida que sejam disponíveis dados coletados a diferentes níveis de aquisição (Novo, 1992).

Um segmento de paisagem é tipicamente composto por manchas que são descontínuas em algum aspecto físico ou biológico. A variação topográfica, por exemplo, pelo seu efeito no ar e fluxo de água e ângulo solar, pode induzir diferenças na composição de espécies e desenvolvimento do solo em um contínuo de fragmentos de escalas. Estes fragmentos de paisagem podem ser observados pelo solo, vegetação, relevo e outros atributos como indicadores. Planejadores e analistas de impactos freqüentemente usam as características de distinção de uma paisagem para predizer o efeito de ações em fragmentos da paisagem e por fim, em toda a paisagem (Westmann, 1985).

Uma das formas de classificação do terreno é utilizar a combinação de informações sobre vários componentes do ecossistema, como o solo, vegetação, relevo e clima, como unidades ecológicas do mapa. A razão para este procedimento é que as unidades ecológicas derivam de uma ampla base de informações e podem ser um indicador mais potente de uma gama de recursos da terra. Uma dificuldade com o estudo é que os limites naturais para as diferenças do solo, vegetação, relevo e clima nem sempre coincidem. Alguns critérios podem ser usados para estabelecer limites. Desde que isto envolve o julgamento pelo responsável pelo mapeamento, a replicação por outras pessoas é mais difícil.

Em muitos casos, a declividade, é o principal a determinar sua capacidade de uso. O termo uso da terra refere-se à utilização "cultural” da terra, enquanto que o termo 
cobertura da terra refere-se a seu revestimento. Os aspectos topográficos de interesse para os planejamentos agrícolas podem ser identificados com auxílio de um mapa planialtimétrico, com clinômetro ou o exame de fotografias aéreas e informações contidas em mapas digitais (Lepsch et al., 1983). As declividades de cada gleba são enquadradas dentro de determinados intervalos de declividade, os quais definem as classes.

Exemplos sobre a utilização dos SIGs para estudos ambientais são bastante encontrados no Brasil, principalmente para o Estado de São Paulo, como é o caso do livro “Estação Ecológica de Jataí” (Santos \& Pires, 2000), que apresenta uma coletânea de artigos científicos realizados naquela Estação Ecológica, principalmente sobre os aspectos fisiográficos da região. 


\section{MATERIAL E MÉTODOS}

\section{1 Área de Estudo}

Para este estudo, alguns rios principais de quatro bacias hidrográficas foram selecionados, a saber, Bacia do rio do Peixe, Bacia do rio Aguapé́, Bacia do rio São José dos Dourados e Bacia do Alto Paranapanema; nesta última, além do rio principal, outros dois rios tiveram sua fauna amostrada.

A Figura 1 apresenta um mapa do Estado de São Paulo, com os limites das bacias hidrográficas. Os locais de coleta estão indicados por um círculo vermelho.

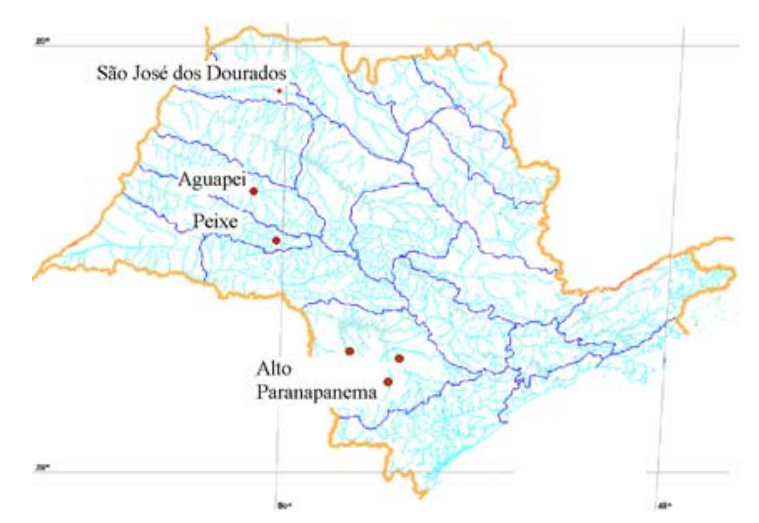

Figura 1 - Representação do Estado de São Paulo com indicação dos pontos de coleta

\subsubsection{Bacia Hidrográfica do Alto Paranapanema}

A bacia possui uma área de drenagem de $22.550 \mathrm{~km}^{2}$, sendo os seus principais cursos d’água o rio Paranapanema, o rio Apiaí-Guaçu, o rio Taquari, o rio Itapetininga, o rio Verde, o rio Capivari, o rio Itararé e o Ribeirão das Almas.

A declividade média total do rio Paranapanema, desde suas nascentes até a desembocadura no rio Paraná é de $61 \mathrm{~cm} . \mathrm{km}^{-1}$.

De acordo com o Plano Estadual de Recursos Hídricos, a bacia hidrográfica do Alto Paranapanema é classificada como área de conservação, destacando-se como 
região caracteristicamente agrícola, sendo a parte mais a montante coberta por enormes áreas reflorestadas e matas naturais. Os rios, quase na totalidade, são considerados pertencentes à Classe Dois.

Além de se destacar como região tipicamente agrícola; o turismo e o lazer são atividades importantes devido à presença de Unidades de Conservação Ambiental e represas com utilização múltipla da água.

A bacia é composta por terrenos com formas de relevo predominante representados pelos morros baixos com topos convexos, com altitudes variando entre $700 \mathrm{~m}$ e $800 \mathrm{~m}$ e declividades entre $20 \%$ e $30 \%$, com entalhamento de vales variando entre $20 \mathrm{~m}$ e $40 \mathrm{~m}$ e dimensão interfluvial entre $250 \mathrm{~m}$ e $750 \mathrm{~m}$.

A região possui algumas áreas protegidas, como as Estações Ecológicas de Angatuba, Itaberá, Itapeva e Paranapanema, a Floresta Nacional de Capão Bonito e a Área de Proteção Ambiental Botucatu, Tejupá. Conta, também, com algumas áreas indígenas disseminadas pela região.

Na bacia do Alto Paranapanema não existem grandes fontes de degradação ambiental, mesmo considerando as contribuições dos municípios e indústrias. Deve-se destacar, no entanto, a presença de erosões, que é generalizada na bacia e ocorre em cerca de $80 \%$ dos municípios, principalmente a montante da represa de Chavantes, ao longo do rio Itararé.

Os processos erosivos e de assoreamento da bacia estão associados principalmente aos diversos fatores a seguir descritos:

- Erodibilidade do solo;

- Fatores de uso e manejo e práticas conservacionistas;

- O comprimento da encosta e a sua declividade;

- O potencial natural à erosão laminar, tendo por base valores de uso e manejo e de práticas conservacionistas que refletem as técnicas agrícolas mais utilizadas na área e tendo em vista a máxima tolerância de perdas de solo por erosão.

Sua área é caracteristicamente agrícola, sendo a parte mais a montante, coberta por enormes áreas reflorestadas e matas naturais. Parte da área da bacia é utilizada para pastagens e culturas de feijão, milho, café e arroz, ressaltando-se o incremento de cana- 
de-açúcar nas terras roxas da região de Ourinhos. As principais atividades industriais são alimentícia, celulose e papel, engenhos e destilarias (Tomazelli, 2003).

Apesar de ser considerada pelos órgãos gestores uma bacia de preservação, os três rios estudados apresentavam uma mata ripária escassa com poucas árvores esparsas e alguns arbustos. Os rios Apiaí-Guaçu e Taquari apresentavam largura e profundidade bastante semelhantes, enquanto que o rio Paranapanema era o mais raso (Tabela 2).

Tabela 2. Informações sobre os locais de coleta na bacia do Alto Paranapanema

\begin{tabular}{lccc}
\hline & Rio Paranapanema & Rio Apiaí-Guaçu & Rio Taquari \\
\hline Profundidade & $0,5 \mathrm{~m}$ & $1,4 \mathrm{~m}$ & $1,8 \mathrm{~m}$ \\
Largura & $17,5 \mathrm{~m}$ & $15 \mathrm{~m}$ & $17 \mathrm{~m}$ \\
Latitude & $23^{\circ} 90^{\prime} 79^{\prime}$ & $23^{\circ} 93^{\prime} 11^{\prime}$ & $23^{\circ} 96^{\prime} 91^{\prime}$ \\
Longitude & $48^{\circ} 25^{\prime} 96^{\prime}$ & $48^{\circ} 65^{\prime} 78^{\prime}$ & $48^{\circ} 94^{\prime} 61^{\prime}$ \\
\hline
\end{tabular}

\subsubsection{Bacias Hidrográficas dos rios do Peixe e Aguapeí}

A bacia do rio Aguapeí e a do rio do Peixe, por apresentarem muitas semelhanças físicas e por possuírem um nível de atividade antrópica que produz uma interferência muito grande entre si, foram inseridas em um único Comitê de bacia hidrográfica (relatório do Comitê de bacia hidrográfica dos rios do Peixe e Aguapeí). Para a descrição geral da área de estudo, as duas unidades serão tratadas como uma grande bacia, seguindo o exemplo do Comitê destas bacias hidrográficas.

Ambas bacias possuem a maioria das cidades exatamente nos divisores de água, tornando difícil o tratamento dos dados físicos e também as informações sobre o uso do solo e da água, por sub-bacias. No entanto, de acordo com o relatório do Comitê, a forma alongada da bacia, sua grande extensão e a diversidade de alguns fatores do meio físico, como a geomorfologia, sugerem a necessidade da divisão destas duas unidades de gerenciamento em unidades menores.

O clima da região é classificado como tropical quente e úmido (com chuvas de verão), com um a dois meses de estação seca (inverno). A precipitação média anual é de 
$1250 \mathrm{~mm}$ e a temperatura média anual, superior a $18^{\circ} \mathrm{C}$. Próximo ao rio Paraná, a umidade relativa do ar é maior.

Os rios Aguapeí e do Peixe são pertencentes à Classe Dois. O comprometimento dos recursos hídricos é de tal magnitude que praticamente todas as drenagens encontram-se impactadas pelo assoreamento, não possibilitando uma hierarquização de criticidade.

\subsubsection{Bacia do rio Aguapeí}

A Unidade de Gerenciamento do rio Aguapeí possui área de drenagem de $12.011 \mathrm{~km}^{2}$. O rio Aguapeí é formado pela junção dos rios Feio e Tibiriçá, tendo uma extensão de aproximadamente $420 \mathrm{~km}$ até sua foz no rio Paraná.

O uso da terá é destinado às atividades urbanas e industriais e à agropecuária, com áreas de pastagem e cultivo de milho, amendoim, cana-de-açúcar, arroz, algodão, feijão, frutas, citros e hortaliças, além de pequena área de vegetação natural. A agroindústria é a principal atividade industrial na região (Tomazelli, 2003).

No trecho de rio navegado para seleção dos locais a serem amostrados, a mata ripária apresentava um bom estado de conservação, intercalada por regiões de clareiras, que foram selecionadas como ambiente de pastagem.

Este rio apresentava, no trecho de coleta, largura em torno de $48 \mathrm{~m}$ e profundidade de 1,2m. A localização geográfica do local de mata é $50^{\circ} 26^{\prime} 71^{\prime \prime} \mathrm{W}$ e

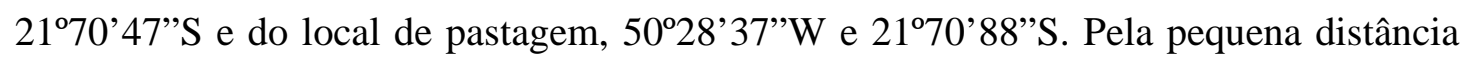
percorrida entre os pontos, apenas o primeiro deles em cada uso da terra foi apresentado.

\subsubsection{Bacia do rio do Peixe}

Possui uma área de drenagem de $9.156 \mathrm{~km}^{2}$ e o rio principal, homônimo à bacia, mede 380km de extensão, desembocando no rio Paraná. O uso da terra é destinado as atividades urbanas, industriais e à agropecuária, com destaque para áreas de pastagem, além das culturas de café, milho e cana-de-açúcar. As principais atividades industriais são as agroindústrias e indústrias alimentícias (Tomazelli, 2003). 
O rio do Peixe, de acesso mais difícil, foi percorrido a pé. O trecho analisado apresentava mata ripária com poucas árvores, entremeada por regiões mais densas, mas que não se enquadravam no estabelecido na legislação. No local de coleta, o rio do Peixe apresentava largura do canal de 17,5m e profundidade de 0,5m. Este ponto de coleta

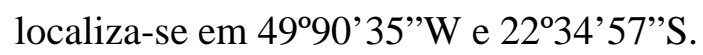

\subsubsection{Bacia Hidrográfica do rio São José dos Dourados}

A bacia do rio São José dos Dourados está localizada no extremo noroeste do Estado, possuindo $6.142 \mathrm{~km}^{2}$ de extensão, com 41 municípios. O rio São José dos Dourados é classificado como pertencente à Classe Dois.

Em termos de distribuição das categorias de uso e ocupação do solo, a vegetação natural ocorre disseminada em toda a região, formando pequenos maciços, como na parte central da bacia, ou acompanhando os principais cursos d’água, caracterizando as matas-ripárias, principalmente ao longo do rio São José dos Dourados.

As pastagens e os campos antrópicos são predominantes em toda a bacia, especialmente na porção noroeste, a norte do ribeirão Ponte Pensa, e na porção centroleste, abrangendo os municípios de Nhandeara, Votuporanga e Cosmorama.

O rio São José dos Dourados, assim como o rio Aguapeí, apresentava mata ripária bem preservada, seguida de trechos de menor densidade de árvores, em alguns casos sendo ausentes; estes últimos foram selecionados como locais de pastagem. No local de coleta, o rio apresentava largura de $21,7 \mathrm{~m}$ e profundidade de $0,4 \mathrm{~m}$. A localização geográfica do trecho de mata é 20³2’14”S e 5001'25”W e do trecho de pastagem, $20^{\circ} 32^{\prime} 28^{\prime \prime}$ s e $50^{\circ} 01^{\prime} 46^{\prime \prime} \mathrm{W}$.

\subsection{Estudo em Escala Regional}

\subsubsection{Coleta dos Insetos Aquáticos}

O método escolhido para coleta dos insetos foi o mesmo para os dois estudos conduzidos. Após analisar algumas metodologias (rede de mão, dragas e cestos com substrato artificial), optou-se pelo uso de cestos com substrato artificial. Como todos os 
métodos, os cestos com substrato artificial apresentam restrições, entretanto, mostraramse maleáveis no uso e mais eficientes em relação à profundidade do rio e ao fluxo da água; além disso, o uso de substrato artificial para amostragem coleta maior número de espécies de invertebrados bentônicos que as amostras feitas por dragagem (Dickson et al., 1971).

Estes cestos foram confeccionados com telas plásticas de malha hexagonal e abertura de 2,0cm, contendo argila expandida e pedregulhos. O uso de uma malha de 0,2mm para diminuir a perda de insetos no ato da retirada dos cestos do rio (Richard et al., 1997) foi testado, porém sua eficácia não foi comprovada e descartou-se este método.

O uso de material orgânico, como folhas e pedaços de madeira, também foi testado. Apesar de coletar maior número de indivíduos, a riqueza taxonômica e a abundância relativa dos táxons foram semelhantes para os cestos com matéria orgânica e aqueles contendo somente pedregulhos. Devido aos resultados obtidos, verificou-se que não havia necessidade de utilizar matéria orgânica como substrato para coleta dos organismos.

Estudos realizados sobre as relações entre comunidades bentônicas e natureza do substrato mostraram que essa comunidade tem preferência por partículas de tamanhos diferentes. A utilização de substratos artificiais padronizados seria uma forma de amenizar os problemas de variabilidade do substrato em locais a serem estudados e comparados (Cummins \& Lauff, 1969).

Neste estudo em escala regional, objetivou-se analisar a qualidade da água de rios de algumas bacias hidrográficas do Estado de São Paulo através da composição numérica e taxonômica das comunidades de insetos capturadas com cestos com substrato artificial. Para isso, a coleta foi feita na época de estiagem, entre agosto e outubro de 2002, assim, os cestos permaneceram em campo por 44 dias, para colonização pelos organismos (Crenshaw \& Valett, 2002).

Uma vez que nem todos os locais apresentavam a área de mata ripária adequadamente preservada e, para padronização dos locais de modo a permitir uma comparação entre as comunidades dos diferentes rios, locais que apresentavam o mesmo 
visual de pastagem ao longo dos rios foram selecionados para colocação dos cestos. Além disso, com a intenção de diminuir influências de outras atividades antrópicas, a presença de $500 \mathrm{~m}$ de pastagem a montante do primeiro local a serem colocados os cestos foi requerida.

Os cestos foram colocados nos rios, ficando parcialmente enterrados no sedimento, para auxiliar na colonização pelos organismos bentônicos, a uma distância média de $0,8 \mathrm{~m}$ das margens. Três lotes contendo três cestos cada foram colocados em cada margem dos rios, cada lote distando no mínimo 150m entre si (Figura 2).

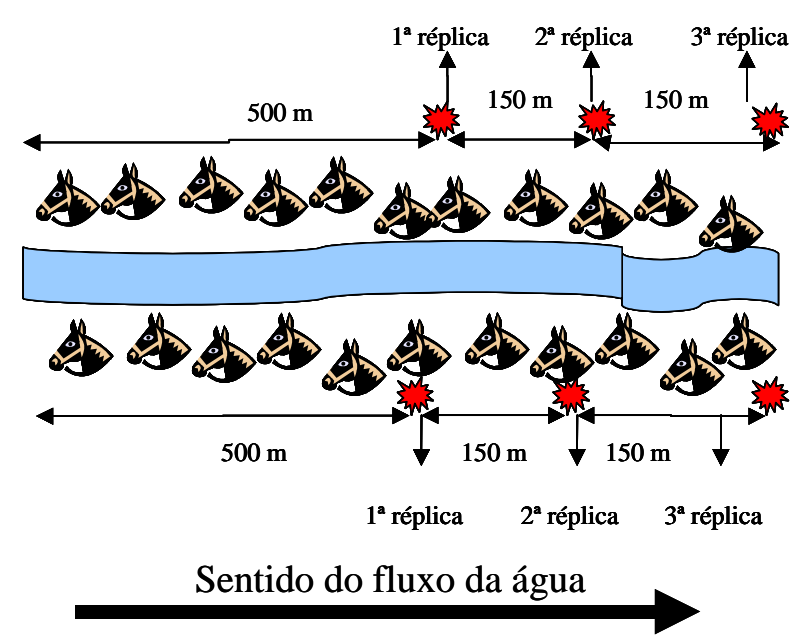

Figura 2 - Esquema da disposição das réplicas ao longo do rio

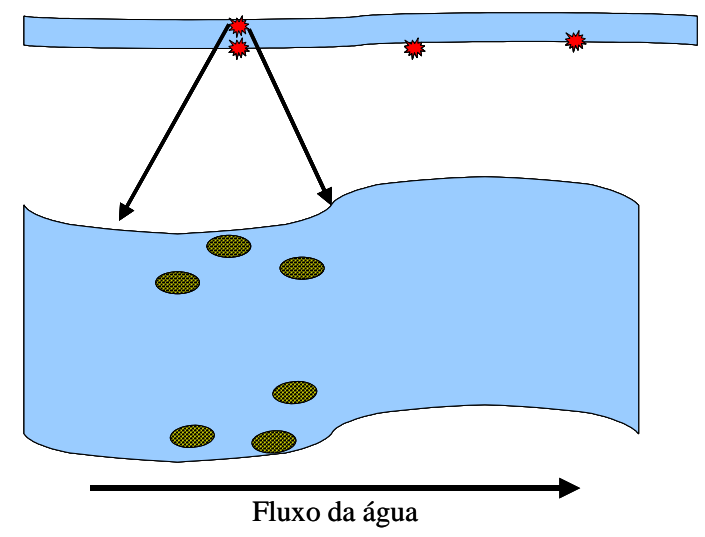

Figura 3 - Disposição dos cestos em cada lote 
Um cuidado que foi tomado para a colocação dos cestos, foi a certificação de que os locais fossem a montante de pontes ou estradas; já que estudos demonstraram que estas podem influenciar na comunidade biótica dos corpos d’água, pela poluição das águas ou introdução de material alóctone (Trombulak \& Frissell, 2000).

Uma vez que as margens são fortemente influenciadas pelas áreas adjacentes e tipicamente contêm elementos derivados diretamente destes locais, como raízes, madeiras e vegetação terrestre que são carreadas para o rio, o canal tende a ser menos influenciado pelas margens. A importância na diferenciação das margens é que as áreas marginais contêm comunidades mais ricas em organismos que áreas do canal, como resultado do aumento de complexidade das áreas marginais.

A Figura 4 apresenta as condições nas quais alguns cestos foram encontrados na data de retirada.

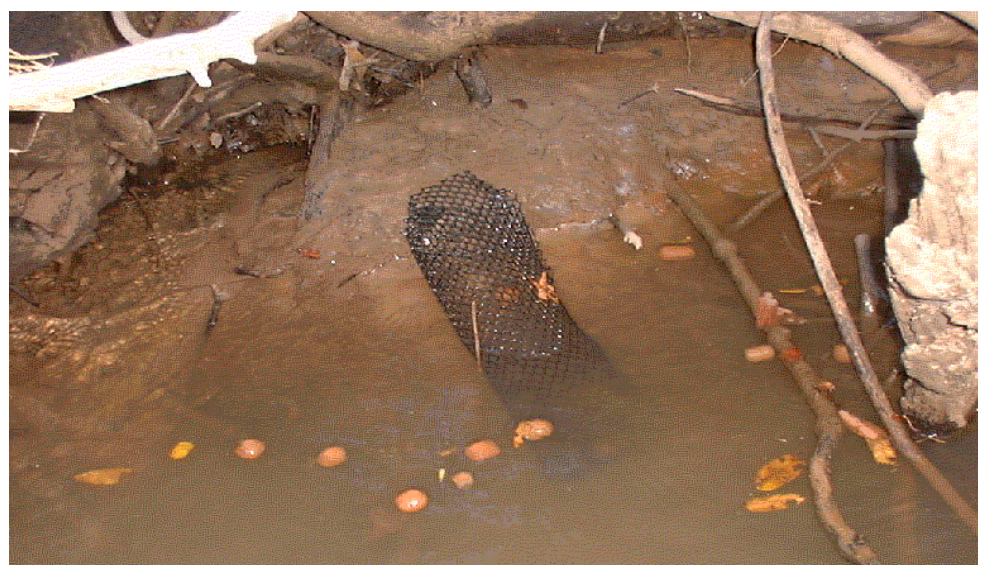

Figura 4 -Cesto depredado, detalhe dos substratos boiando próximos ao mesmo

O material coletado foi acondicionado em sacos plásticos (Figura 5), preservado com formol a $4 \%$ e transportado ao laboratório, onde foi manuseado. No laboratório, o substrato foi lavado em água corrente utilizando-se uma rede de malha de abertura de 0,21mm para retenção dos macroinvertebrados (Trivinho-Strixino \& Strixino, 1998). O material retido foi colocado em bandeja plástica e os insetos foram triados com auxílio de aparato trans-iluminador; os mesmos foram preservados em álcool a 70\% (Humphries et al., 1998; Pinder, 1989). 


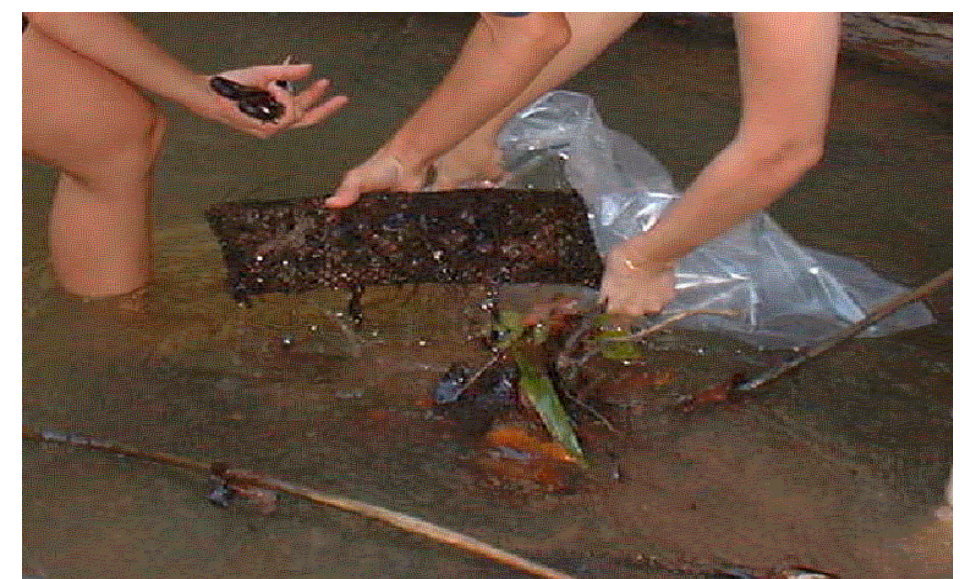

Figura 5 - Retirada de cesto de substrato artificial do rio e acondicionamento em saco plástico

\subsubsection{Identificação Taxonômica}

Os espécimens foram identificados e contados sob esteromicroscópio e microscópio óptico. A identificação de Chironomidae foi feita em nível genérico com auxílio de literatura específica (Trivinho-Strixino \& Strixino, 1995); enquanto que os outros táxons foram identificados em nível de família (Epler, 1996; McCafferty, 1981; Nieser \& Melo, 1997).

Tanytarsini Morfotipo O é uma nova espécie descrita por Sonoda \& TrivinhoStrixino, cuja publicação é aguardada (Sonoda \& Trivinho-Strixino, no prelo).

\subsubsection{Confecção e Classificação dos Mapas de Uso da Terra}

A digitalização dos mapas de uso da terra e os cálculos associados (porcentagem de cada uso do solo e outros) foram feitos com base em imagens de satélite LANDSAT, com resolução de 30m, cedidos por Silva (2002). A avaliação da exatidão da classificação foi feita através da checagem de 230 pontos no campo. O nível de acerto nas medidas foi de 90,1\%, com o valor do índice de Kappa de 0,851 (SILVA et al., submetido). As classes de cobertura do solo estabelecidas foram: pastagem, florestas remanescentes (englobando a Mata Atlântica e o Cerrado), áreas urbanas, culturas perenes (principalmente citricultura, café e seringueiras), culturas anuais (milho e soja, 
principalmente), silvicultura (Eucalyptus spp. e Pinus spp.), cana-de-açúcar, corpos aquáticos, solo exposto e outros (Kronka, 2002; Silva et al., op. cit.).

Com base nestes mapas e utilizando-se os programas IDRISI 32 e ArcView 3.1, foram geradas as informações necessárias para este estudo, como limites e áreas das subbacias, porcentagem da área de cada uso da terra e declividade do terreno.

A delimitação das sub-bacias foi realizada com o modelo SWAT, rodando justamente com o ArcView 3.1. A partir da imagem digital e da rede hidrográfica, fez-se o processamento das informações e criaram-se pontos de confluência dos principais cursos d’água. A partir disso, o programa processou os dados novamente e criou uma imagem da microbacia a montante destes pontos de coleta.

Após a geração desta imagem da sub-bacia, esta foi importada ao IDRISI, onde então foi sobreposta a algumas imagens para gerar novas informações. Da sobreposição do limite com a imagem digitalizada da bacia em questão, obteve-se uma imagem apenas da sub-bacia a ser trabalhada. Com esta imagem, foi possível calcular a área da sub-bacia. Em seguida, a área da zona tampão (buffer) foi gerada a partir de mapas digitais da rede hidrográfica das bacias. Pela sobreposição de imagens, calculou-se a área de cada cobertura/uso do solo nas sub-bacias e também na zona tampão.

A declividade do terreno também foi calculada com base nas imagens geradas acima, para a sub-bacia como um todo e para a área tampão, isoladamente. As classes de declividade do terreno utilizadas seguiram metodologia de Lepsch et al. (1983):

Classe 1 - declives inferiores a $2 \%$;

Classe 2 - declives entre $2 \%$ a $5 \%$;

Classe 3 - declives entre 5\% a 10\%;

Classe 4 - declives entre $10 \%$ a 15\%;

Classe 5 - declives entre 15\% a 45\%;

Classe 6 - declives entre 45\% a 70\%;

Classe 7 - declives superiores a 70\%. 


\subsubsection{Análises Químicas e Físicas da Água}

Estas análises foram conduzidas por pesquisadores do Laboratório de Ecologia Isotópica do CENA/USP, que cederam os resultados para avaliar a interação entre estas variáveis e a comunidade de insetos aquáticos. Ver Salomão (2004), para análises químicas e físicas da água.

Para caracterização local dos pontos de coleta, amostras de sedimento foram coletadas para análise granulométrica, realizada no laboratório de solos do Departamento de Solos e Nutrição de Plantas da ESALQ/USP.

\subsubsection{Análise dos Resultados}

Devido ao elevado número de insetos presentes nas amostras, fato que não era esperado devido aos resultados dos estudos-piloto, optou-se por diminuir o número de cestos a terem seu material analisado. Assim, selecionaram-se aleatoriamente seis cestos para este estudo. Os resultados são apresentados na forma de número total de indivíduos de cada táxon presente no ambiente e analisados segundo a riqueza faunística (número operacional de táxons) e a porcentagem dos táxons nas comunidades.

Os índices comunitários descritos a seguir foram utilizados para auxiliar na caracterização e comparação dos pontos de coleta.

Índice de diversidade de Shannon (Tonhasca Jr, 1994):

$$
H^{\prime}=\sum_{i=1}^{s} p i \log p i
$$

Sendo:

$\mathrm{pi}=\mathrm{Ni} / \mathrm{N}$,

Ni: número de indivíduos de cada táxon;

$\mathrm{N}$ : número total de indivíduos de todos os táxons coletados.

Atualmente, propõe-se o termo "índice de diversidade mínima do sistema" para o índice de Shannon, permitindo o seu uso mesmo quando a identificação em nível específico não é possível, utilizando, portanto, o menor nível taxonômico alcançado na identificação. 
Índice de riqueza de espécies de Margalef (Odum, 1983):

$$
I_{M g}=\frac{S-1}{\log N}
$$

Sendo:

S = número de espécies

Índice de uniformidade de Pielou:

$$
E=\frac{H^{\prime}}{\log S}
$$

O índice Ephemeroptera, Plecoptera e Trichoptera (EPT) também foi testado. O alto valor deste índice, que considera a quantidade numérica de indivíduos destas ordens presentes no ambiente, indica grande preservação do habitat (Sandin \& Johnson, 2000). Scarsbrook et al. (2000) retiraram Hydroptilidae (Trichoptera) do cálculo deste índice porque esta família é freqüentemente associada a hábitats degradados.

Foi utilizada a análise de uma zona tampão para extrair dados da paisagem para uma região de 50m de cada lado do rio. Esta zona tampão foi determinada por considerar o estipulado pela legislação ambiental e também por se saber que algumas funções do rio respondem a características ripárias de uma distância de 100m do rio (Richards et al., 1996). Este procedimento permitiu comparar elementos da paisagem dentro do corredor com dados derivados para a sub-bacia a montante do local de coleta. Análises idênticas foram realizadas com dados da zona tampão e da sub-bacia para determinar as inter-relações entre os insetos, variáveis físicas e químicas da água e usos da terra.

Análises estatísticas foram utilizadas para integralizar os dados sobre os insetos e os usos da terra e declividade do terreno, assim como às variáveis físicas e químicas da água. Neste estudo, a qualidade da água dos rios foi analisada em função dos táxons presentes e as possíveis influências das variáveis, primeiramente utilizou-se a correlação de Pearson para verificar a relação linear que existe entre as variáveis (usos da terra, declividade do terreno e físicas e químicas da água) com as famílias e com os gêneros 
(Anexo A). Também foram analisadas as possíveis diferenças entre os rios de acordo com as variáveis físicas e químicas da água, através da análise de variância (ANOVA). Com esta análise, dez das 19 variáveis apresentaram influência significativa na caracterização dos rios. Neste caso, as variáveis selecionadas para análises posteriores foram condutividade, carbono inorgânico dissolvido (DIC), Cl, $\mathrm{NO}_{2}, \mathrm{NO}_{3}, \mathrm{SO}_{4}, \mathrm{Na}, \mathrm{K}$, Mg e Ca (Anexo B). Após estas análises, utilizou-se a técnica estatística de análise de correspondência, que é uma técnica multivariada descritiva para análise exploratória de dados categorizados. Ela converte uma matriz de dados em um tipo particular de gráfico que exibe as linhas e colunas da matriz como pontos de um espaço vetorial de dimensão menor que a original, de modo que as relações entre as linhas, colunas e entre linhas e colunas possam se interpretadas conjuntamente.

O desenvolvimento teórico da análise de correspondência está baseado em dois aspectos, geométrico e algébrico, e que fazem com que ela pertença a uma família de técnicas de disposição gráfica que são baseadas em aproximação de matrizes, por outra de posto menor por meio da decomposição em valores singulares.

Assim, o problema da análise de correspondência passa a ser o de estimar um subespaço que melhor ajuste a nuvem de pontos no espaço euclidiano. Este ajuste é feito pelo método de quadrado mínimo ponderado onde são utilizadas a distância euclidiana ponderada (distância Qui-quadrado) e a massa de pontos como seu peso.

A abordagem da análise de correspondência enfatiza a representação geométrica revelando a estrutura dos dados de forma ótima e sem necessidade de suposição de modelo de distribuição para os dados.

Desta forma, pode-se dizer que um dos objetivos da análise de correspondência é reduzir a dimensão do espaço vetorial, conservando da melhor forma possível a configuração inicial. Isto significa que se pode considerar esta análise como sendo um algoritmo de redução de dados, que fornece imagens simplificadas da realidade multidimensional e busca a melhor representação simultânea dos conjuntos de categorias da matriz de dados (Ortega, 1997). 


\subsection{Estudo em Escala Local}

\subsubsection{Coleta dos Insetos Aquáticos}

Neste estudo, analisou-se a influência da presença da mata ripária ao longo dos rios sobre a comunidade dos insetos aquáticos. Desta forma, locais com mata ripária bem preservada e locais onde a mata foi substituída por pastagem, nos rios Aguapeí e São José dos Dourados, foram selecionados como áreas de estudo.

Para a coleta, estabeleceu-se que três repetições de três subunidades seriam dispostas em cada margem de cada trecho de rio amostrado, de acordo com o uso do solo, mata ripária ou pasto. Foi estipulado que cada uso da terra deveria ter, no mínimo, 500m da categoria em questão ao longo das margens dos rios antes de colocar a primeira repetição de cestos. A partir deste ponto, deixou-se um espaçamento de 150m entre cada repetição (Figuras 6 e 7). Este procedimento foi adotado para neutralizar qualquer influência do uso do solo a montante do ponto de coleta e também para permitir que a fauna local seja expressiva do uso do solo estudado.

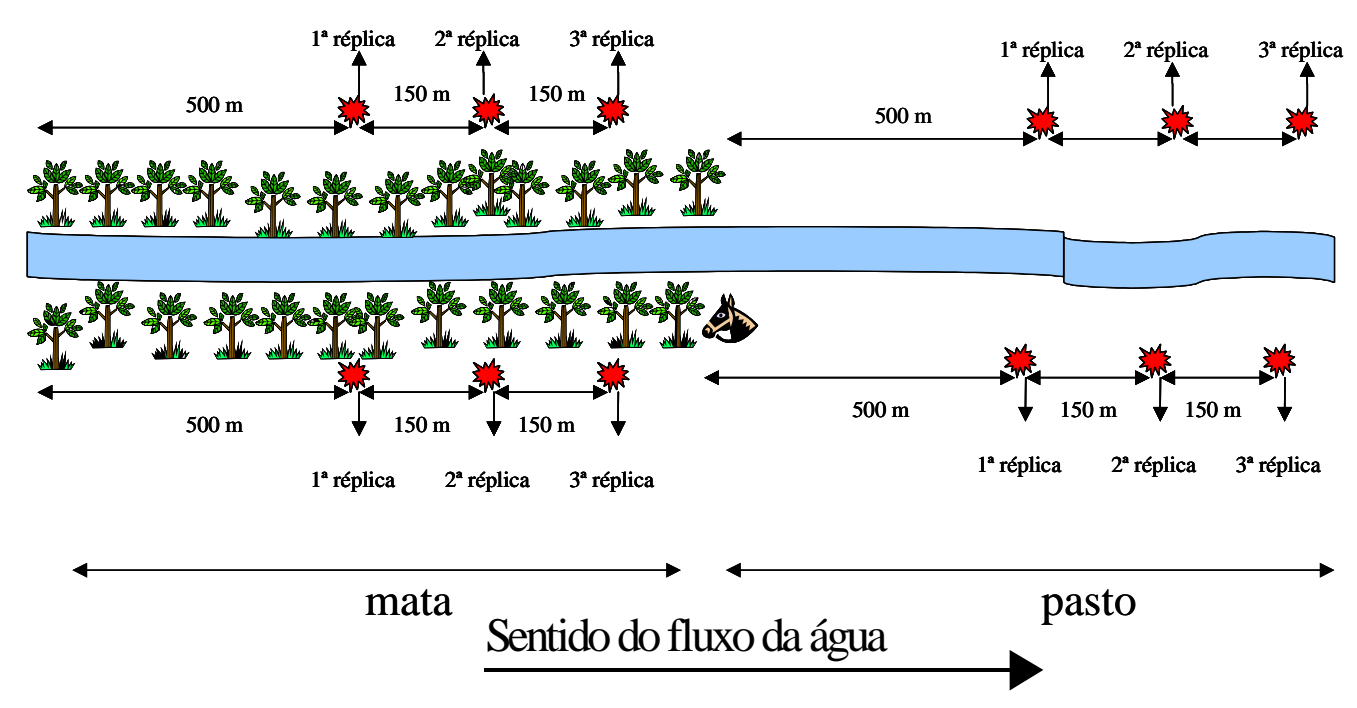

Figura 6 - Esquema da disposição das réplicas ao longo do rio 


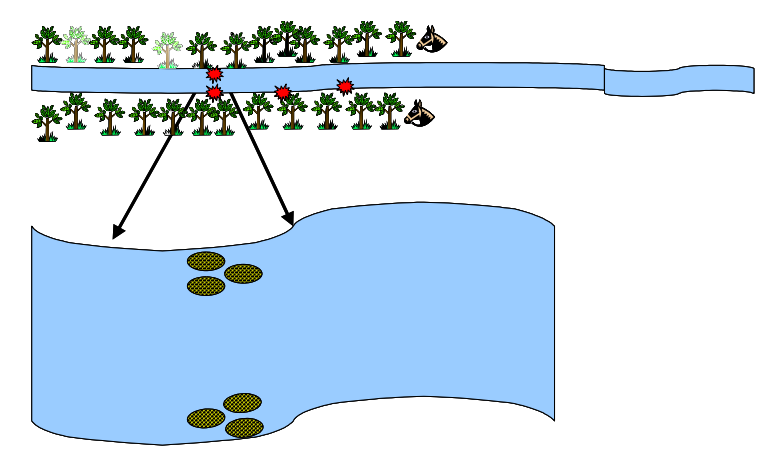

Figura 7 - Detalhe da disposição dos cestos de substratos artificiais nas margens nos pontos amostrais

\subsubsection{Identificação Taxonômica}

O mesmo procedimento adotado no estudo em escala regional para identificação dos táxons foi adotado aqui. Assim, os espécimens foram identificados e contados sob esteromicroscópio e microscópio óptico. A identificação de Chironomidae foi feita em nível genérico com auxílio de literatura específica (Trivinho-Strixino \& Strixino, 1995); enquanto que os outros táxons foram identificados em nível de família (Epler, 1996; McCafferty, 1981; Nieser \& Melo, 1997).

Tanytarsini Morfotipo O é uma nova espécie descrita por Sonoda \& TrivinhoStrixino, cuja publicação é aguardada (Sonoda \& Trivinho-Strixino, no prelo).

\subsubsection{Análise dos Resultados}

De maneira geral, os resultados foram analisados de forma bastante semelhante ao estudo em escala regional; sendo apresentados na forma de número total de indivíduos de cada táxon presente no ambiente, e analisados segundo a riqueza faunística (número operacional de táxons) e a porcentagem dos táxons nas comunidades.

Os índices comunitários a seguir foram utilizados para auxiliar na caracterização e comparação dos pontos de coleta.

Índice de diversidade de Shannon (Tonhasca Jr, 1994):

$$
H^{\prime}=\sum_{i=1}^{s} p i \log p i
$$


Sendo:

$\mathrm{pi}=\mathrm{Ni} / \mathrm{N}$,

Ni: número de indivíduos de cada táxon;

$\mathrm{N}$ : número total de indivíduos de todos os táxons coletados.

Índice de riqueza de espécies de Margalef (Odum, 1983):

$$
I_{M g}=\frac{S-1}{\log N}
$$

$\mathrm{S}$ = número de espécies

Índice de uniformidade de Pielou:

$$
E=\frac{H^{\prime}}{\log S}
$$

Para a análise da relação entre os usos da terra e os gêneros de Chironomidae foram utilizadas as análises de variância (ANOVA) e de covariância (ANCOVA) pelo programa SPSS ${ }^{\circledR}$ versão 11.0 para Windows. A ANCOVA, por ser um teste de correção, foi importante neste caso devido à diferença no número de amostras analisadas e, conseqüentemente, no número de indivíduos. Os fatores analisados foram rio, uso da terra e a interação rio X uso da terra. Uma vez que a ANOVA é suscetível aos táxons que ocorrem em baixos números e poucas amostras, estes não foram considerados para aplicação do teste. 


\section{RESULTADOS}

\subsection{Estudo em Escala regional}

\subsubsection{Insetos Aquáticos}

Trinta e uma famílias e um morfotipo foram identificados e contados, totalizando 14.657 indivíduos amostrados nas quatro bacias hidrográficas. Como pode ser visto na Tabela 3, a grande maioria dos táxons apresentou baixo número de indivíduos na comunidade, muitas delas sendo restritas a apenas um dos locais.

Tabela 3. Listagem dos táxons coletados em cada rio e seus respectivos números de indivíduos

\begin{tabular}{|c|c|c|c|c|c|c|}
\hline Táxon & Paranapanema & $\begin{array}{l}\text { Apiaí- } \\
\text { Guaçu }\end{array}$ & Taquari & Peixe & Aguapeí & $\begin{array}{c}\text { S. J. } \\
\text { Dourados }\end{array}$ \\
\hline \multicolumn{7}{|l|}{ Coleoptera } \\
\hline Dytiscidae & 0 & 1 & 0 & 3 & 3 & 19 \\
\hline Elmidae & 4 & 14 & 23 & 76 & 54 & 27 \\
\hline Haliplidae & 0 & 0 & 0 & 0 & 20 & 19 \\
\hline Psephenidae & 0 & 0 & 0 & 0 & 0 & 1 \\
\hline \multicolumn{7}{|l|}{ Diptera } \\
\hline Ceratopogonidae & 2 & 0 & 12 & 11 & 57 & 14 \\
\hline Chironomidae & 1.028 & 673 & 902 & 838 & 1.479 & 969 \\
\hline Empididae & 0 & 0 & 0 & 0 & 0 & 6 \\
\hline Ephydridae & 4 & 3 & 10 & 22 & 10 & 0 \\
\hline Simuliidae & 67 & 4 & 2 & 3 & 132 & 0 \\
\hline \multicolumn{7}{|l|}{ Ephemeroptera } \\
\hline Baetidae & 6 & 8 & 4 & 103 & 54 & 21 \\
\hline Caenidae & 0 & 1 & 0 & 16 & 15 & 1 \\
\hline Leptohyphidae & 70 & 63 & 172 & 44 & 319 & 1.587 \\
\hline Leptophlebiidae & 3 & 33 & 38 & 326 & 165 & 1.085 \\
\hline Oligoneuridae & 0 & 0 & 0 & 0 & 32 & 0 \\
\hline
\end{tabular}


Tabela 4. Listagem dos táxons coletados em cada rio e seus respectivos números de indivíduos

\begin{tabular}{|c|c|c|c|c|c|c|}
\hline Táxon & Paranapanema & $\begin{array}{l}\text { Apiaí- } \\
\text { Guaçu }\end{array}$ & Taquari & Peixe & Aguapeí & $\begin{array}{c}\text { S. J. } \\
\text { Dourados }\end{array}$ \\
\hline \multicolumn{7}{|l|}{ Hemiptera } \\
\hline Naucoridae & 0 & 0 & 0 & 0 & 17 & 119 \\
\hline \multicolumn{7}{|l|}{ Lepidoptera } \\
\hline Pyralidae & 0 & 0 & 0 & 1 & 1 & 2 \\
\hline \multicolumn{7}{|l|}{ Megaloptera } \\
\hline Corydalidae & 0 & 0 & 0 & 0 & 0 & 5 \\
\hline \multicolumn{7}{|l|}{ Odonata } \\
\hline Calopterygidae & 0 & 2 & 5 & 7 & 11 & 21 \\
\hline Coenagrionidae & 12 & 11 & 3 & 28 & 6 & 26 \\
\hline Corduliidae & 0 & 1 & 0 & 2 & 2 & 0 \\
\hline Gomphidae & 0 & 0 & 3 & 1 & 1 & 4 \\
\hline Libellulidae & 0 & 1 & 0 & 0 & 0 & 9 \\
\hline Protoneuridae & 0 & 0 & 0 & 0 & 0 & 1 \\
\hline Odonata tipo 1 & 0 & 0 & 0 & 1 & 0 & 0 \\
\hline \multicolumn{7}{|l|}{ Plecoptera } \\
\hline Perlidae & 0 & 0 & 0 & 2 & 6 & 1 \\
\hline \multicolumn{7}{|l|}{ Trichoptera } \\
\hline Glossossomatidae & 0 & 3 & 0 & 0 & 6 & 0 \\
\hline Hydropsychidae & 65 & 170 & 1.474 & 23 & 604 & 882 \\
\hline Hydroptilidae & 0 & 0 & 0 & 0 & 5 & 0 \\
\hline Leptoceridae & 0 & 0 & 0 & 0 & 0 & 5 \\
\hline Odontoceridae & 2 & 10 & 1 & 0 & 0 & 0 \\
\hline Philopotamidae & 4 & 3 & 0 & 0 & 0 & 372 \\
\hline Polycentropodidae & 0 & 0 & 0 & 2 & 26 & 10 \\
\hline
\end{tabular}

Dentre os táxons que se destacaram devido ao elevado número de representantes, Chironomidae foi o único grupo de alta dominância encontrado em todos os locais. O rio São José dos Dourados, apesar do alto número de indivíduos amostrados, contou com quatro táxons dominantes; por outro lado, o rio Paranapanema apresentou apenas os quironomídeos como família numericamente dominante. No rio do Peixe, além de Chironomidae, Leptophlebiidae também apresentaram elevado número de indivíduos (21,6\% do total da comunidade). Hydropsychidae contaram com a maior participação na fauna do rio Taquari. Nos dois rios restantes, Apiaí-Guaçu e Aguapeí, Chironomidae e 
Hydropsychidae foram os grupos dominantes. Os índices comunitários podem ser vistos na Tabela abaixo.

Tabela 5. Valores dos índices comunitários de cada comunidade amostrada

\begin{tabular}{lcccccc}
\hline & Paranapanema & $\begin{array}{c}\text { Apiaí- } \\
\text { Guaçu }\end{array}$ & Taquari & Peixe & Aguapeí & $\begin{array}{c}\text { S. J. } \\
\text { Dourados }\end{array}$ \\
\hline Diversidade & 0,3 & 0,5 & 0,5 & 0,6 & 0,7 & 0,8 \\
Riqueza & 3,9 & 5,3 & 3,5 & 5,7 & 6,0 & 6,8 \\
Uniformidade & 0,3 & 0,4 & 0,4 & 0,5 & 0,6 & 0,6 \\
EPT & 6 & 8 & 5 & 7 & 9 & 9 \\
\hline
\end{tabular}

O índice EPT apresentou valores que variaram bastante, atingindo um mínimo no rio Taquari e maiores valores nos rios Aguapeí e São José dos Dourados.

Em relação aos quironomídeos, vinte e seis gêneros e três morfotipos foram identificados nas amostras dos seis rios (Tabela 5). Dos 29 táxons identificados, seis foram exclusivos a apenas um local. No rio Apiaí-Guaçu, apenas Tribelos spp. foram restritos a este ambiente, correspondendo a 0,3\% da comunidade. Morfotipo O, coletados no rio São José dos Dourados, contaram com 8,6\% dos Chironomidae, Coelotanypus spp. e Denopelopia spp. apesar da baixa participação, também foram registrados somente neste ambiente. O rio Aguapeí foi o que apresentou maior número de táxons exclusivos. Com exceção de Cryptochironomus spp. que representaram 1,3\% da comunidade, os outros táxons (Zavreliella spp., Morfotipos M e Y) foram extremamente raros $(0,7 \% ; 0,7 \%$ e $0,1 \%$, respectivamente).

Tabela 6. Chironomidae amostrados nas bacias hidrográficas, em número de indivíduos

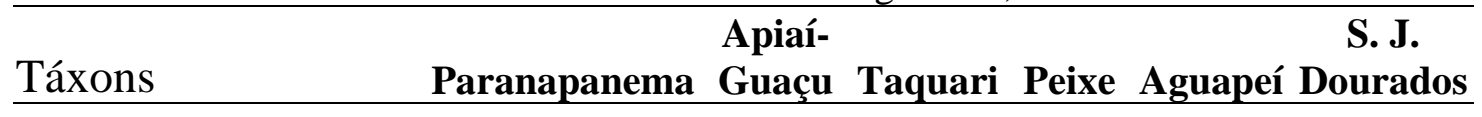

Chironominae

\section{Chironomini}

Beardius spp.

Chironomus spp.

Cryptochironomus spp.

Paranapanema Guaçu Taquari Peixe Aguapeí Dourados

Endotribelos spp.

Fissimentum spp.

Goeldichironomus spp.

Harnischia spp.

$\begin{array}{cccccc}25 & 25 & 3 & 129 & 2 & 1 \\ 6 & 0 & 0 & 0 & 0 & 12 \\ 0 & 0 & 0 & 0 & 16 & 0 \\ 1 & 0 & 0 & 0 & 5 & 0 \\ 3 & 0 & 37 & 4 & 0 & 0 \\ 0 & 1 & 0 & 0 & 0 & 0 \\ 9 & 0 & 11 & 29 & 0 & 0\end{array}$


Tabela 7. Chironomidae amostrados nas bacias hidrográficas, em número de indivíduos

\begin{tabular}{|c|c|c|c|c|c|c|}
\hline Táxons & Paranapanema & $\begin{array}{l}\text { Apiaí- } \\
\text { Guaçu }\end{array}$ & Taquari & Peixe & Aguapeí & $\begin{array}{c}\text { S. J. } \\
\text { Dourados }\end{array}$ \\
\hline Lauterborniella spp. & 21 & 8 & 0 & 1 & 0 & 4 \\
\hline Parachironomus spp. & 0 & 1 & 1 & 0 & 6 & 0 \\
\hline Pol. (Asheum) spp. & 41 & 4 & 3 & 3 & 0 & 0 \\
\hline Pol. (Polypedilum) spp. & 0 & 9 & 18 & 109 & 12 & 0 \\
\hline Stenochironomus spp. & 1 & 0 & 1 & 0 & 1 & 3 \\
\hline Tribelos spp. & 0 & 2 & 0 & 0 & 0 & 0 \\
\hline Zavreliella spp. & 0 & 0 & 0 & 0 & 12 & 0 \\
\hline Morfotipo M & 0 & 0 & 0 & 0 & 12 & 0 \\
\hline Morfotipo Y & 0 & 0 & 0 & 0 & 1 & 0 \\
\hline \multicolumn{7}{|l|}{ Tanytarsini } \\
\hline Rheotanytarsus spp. & 637 & 401 & 645 & 164 & 884 & 402 \\
\hline Morfotipo O & 0 & 0 & 0 & 0 & 0 & 71 \\
\hline \multicolumn{7}{|l|}{ Orthocladiinae } \\
\hline \multicolumn{7}{|l|}{ Orthocladiini } \\
\hline Lopescladius spp. & 2 & 0 & 12 & 53 & 123 & 3 \\
\hline $\begin{array}{l}\text { Nanocladius spp. } \\
\text { Tanypodinae } \\
\text { Coelotanypodini }\end{array}$ & 110 & 113 & 30 & 173 & 217 & 207 \\
\hline $\begin{array}{l}\text { Coelotanypus spp. } \\
\text { Pentaneurini }\end{array}$ & 0 & 0 & 0 & 0 & 0 & 2 \\
\hline Ablabesmyia spp. & 87 & 10 & 87 & 38 & 42 & 121 \\
\hline Denopelopia spp. & 0 & 0 & 0 & 0 & 0 & 2 \\
\hline Labrundinia spp. & 23 & 54 & 10 & 9 & 17 & 50 \\
\hline Larsia spp. & 2 & 1 & 2 & 6 & 8 & 11 \\
\hline Nilotanypus spp. & 9 & 4 & 0 & 1 & 0 & 0 \\
\hline $\begin{array}{l}\text { Pentaneura spp. } \\
\text { Procladiini }\end{array}$ & 15 & 10 & 10 & 5 & 16 & 3 \\
\hline Djalmabatista spp. & 0 & 2 & 0 & 1 & 0 & 1 \\
\hline
\end{tabular}

Seis táxons mostraram dominância numérica em pelo menos um dos rios estudados. Beardius spp. e Polypedilum (Polypedilum) spp. tiveram elevados valores somente no rio do Peixe; nos outros rios, suas participações foram pouco expressivas, 
sendo ausentes em alguns locais. Rheotanytarsus spp. apresentaram elevados valores percentuais em todos os ambientes, entretanto, no rio do Peixe apesar de ser um dos táxons dominantes, contaram com o menor valor percentual dentre os rios (19,2\%). Já Nanocladius spp., que tiveram expressiva participação nos ambientes, foram bastante modestos numericamente no rio Taquari. Corynoneura spp. e Ablabesmyia spp. tiveram maiores valores percentuais em metade dos rios, dominância nem sempre coincidente em relação aos locais.

As diferenças na estrutura das comunidades de cada rio também são evidenciadas pelos valores dos índices comunitários (Tabela 6). O índice de diversidade e a uniformidade apresentaram valores bastante semelhantes, exceto para o rio do Peixe que apresentou valores maiores para estes índices que aqueles encontrados para as comunidades dos outros rios.

Tabela 8. Índices comunitários da fauna de Chironomidae dos rios

\begin{tabular}{lcccccc}
\hline & \multicolumn{3}{c}{$\begin{array}{c}\text { Apiaí- } \\
\text { Paranapanema }\end{array}$} & $\begin{array}{c}\text { Guaçu } \\
\text { Taquari }\end{array}$ & $\begin{array}{c}\text { Peixe } \\
\text { Aguapeí }\end{array}$ & $\begin{array}{c}\text { S. J. } \\
\text { Dourados }\end{array}$ \\
\hline Diversidade & 0,6 & 0,6 & 0,5 & 0,9 & 0,6 & 0,7 \\
Riqueza & 5,3 & 5,3 & 4,7 & 5,1 & 5,0 & 5,0 \\
Uniformidade & 0,5 & 0,5 & 0,4 & 0,8 & 0,5 & 0,6 \\
\hline
\end{tabular}

\subsubsection{Geoprocessamento}

As informações sobre os usos do solo nas bacias foram geradas em relação à subbacia formada a montante do último local de coleta (considerando o sentido do fluxo de água), utilizando o programa ArcView. A partir desta imagem, gerou-se uma nova imagem, com uma área de zona tampão de 50m ao redor dos rios. Além disso, com base nestas duas imagens, pode-se calcular os intervalos de declividade dos terrenos das subbacias e das zonas tampão de cada rio. Valores percentuais das áreas de cada uso da terra e da declividade são apresentados em Anexo C.

Os diferentes usos da terra nas sub-bacias delimitadas a montante de cada local de coleta, formam um gradiente crescente na participação da pastagem, com os rios da bacia do Alto Paranapanema com os menores valores e as sub-bacias do Aguapeí e São 
José dos Dourados com as maiores porcentagens de terra ocupada por esta atividade, enquanto que o rio do Peixe apresentou valor intermediário.

Por outro lado, ao observar a quantidade de mata (vegetação natural remanescente e reflorestamento), nota-se um gradiente contrário ao da pastagem. Neste caso, as subbacias do Alto Paranapanema apresentaram elevada porcentagem de terra ocupada pela mata, enquanto que as sub-bacias dos rios Aguapeí e São José dos Dourados apresentaram os menores valores.

A área urbana foi completamente ausente na maioria das sub-bacias, com exceção daquelas dos rios Aguapeí e São José dos Dourados. Os mapas apresentados na Figura 8 ilustram estes usos da terra nas sub-bacias. 

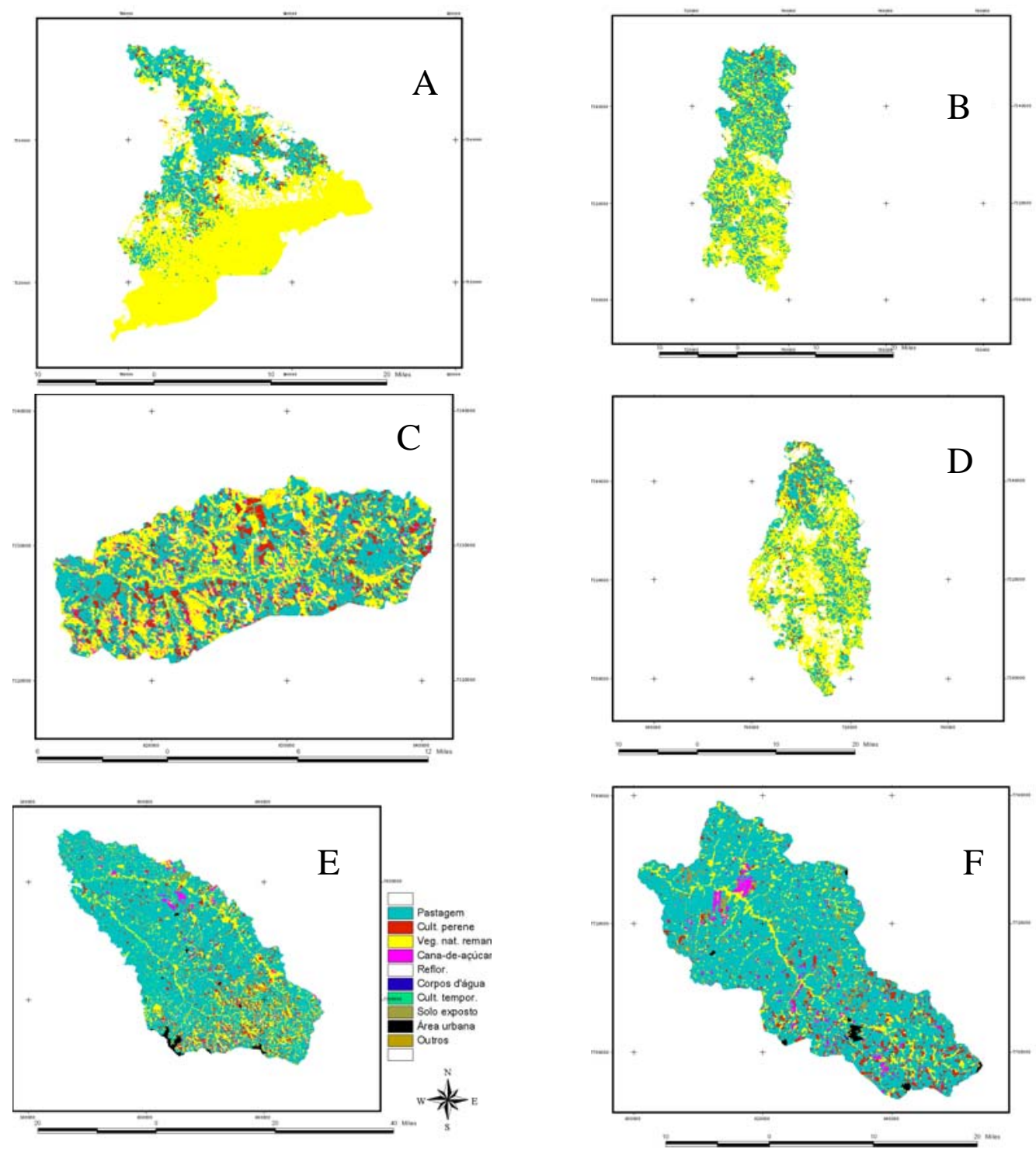

Figura 8 - Mapas dos usos da terra das sub-bacias. Em A - Paranapanema; B - ApiaíGuaçu; C - Peixe; D - Taquari; E - Aguapeí e F - São José dos Dourados

O mesmo padrão de distribuição dos principais usos da terra foi encontrado nas zonas tampão das sub-bacias (Anexo D). Vale ressaltar que por ser uma área de preservação, as ocupações da mata ripária nestas faixas foram um pouco acima das encontradas nas sub-bacias. Apesar do caráter preservacionista da zona tampão, áreas de urbanização foram encontradas ao longo dos rios Aguapeí e São José dos Dourados. A Figura 9 apresenta a distribuição dos usos da terra nas zonas tampão. 

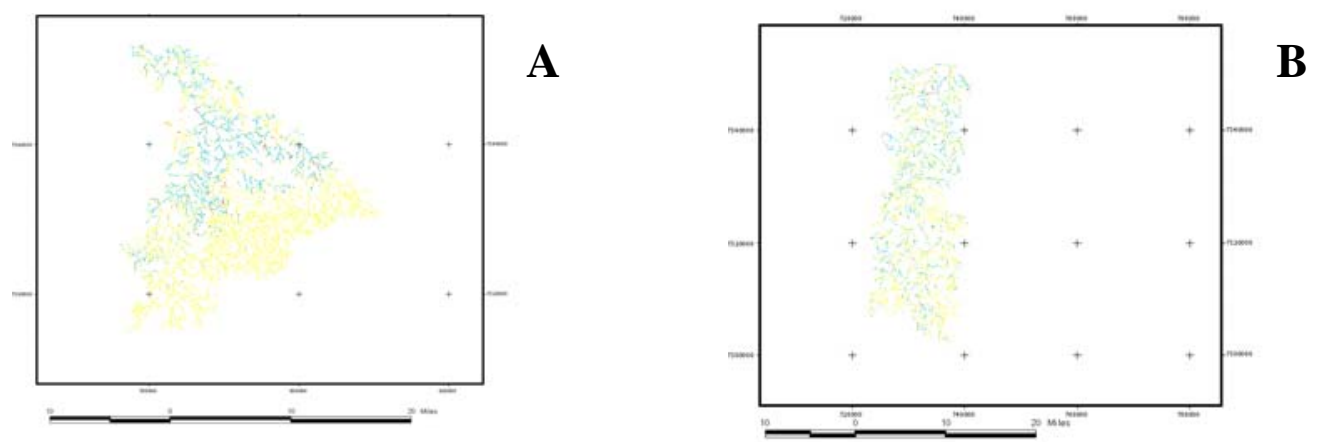

B
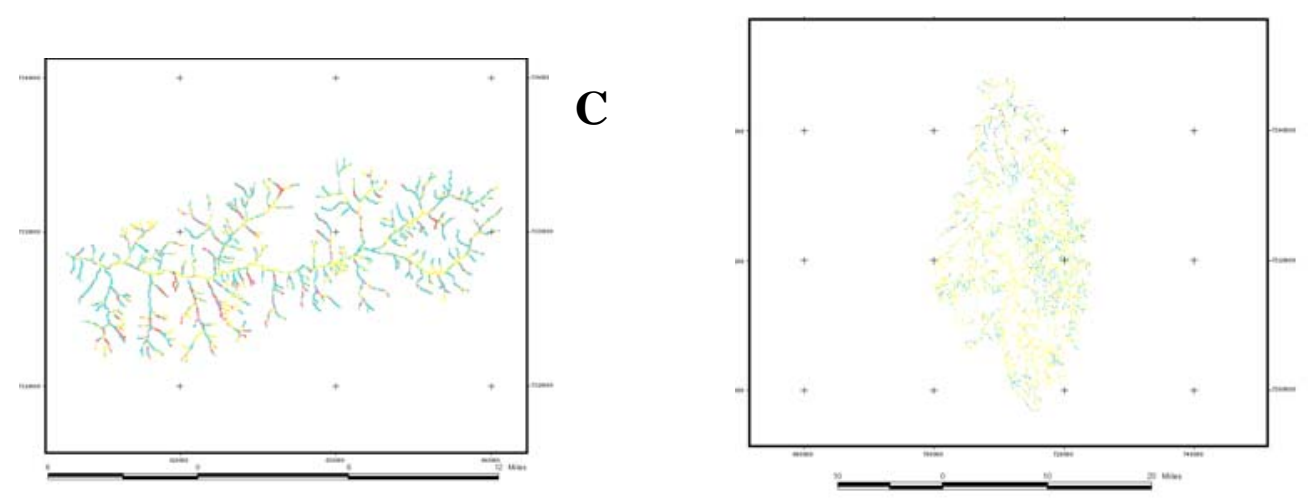

D
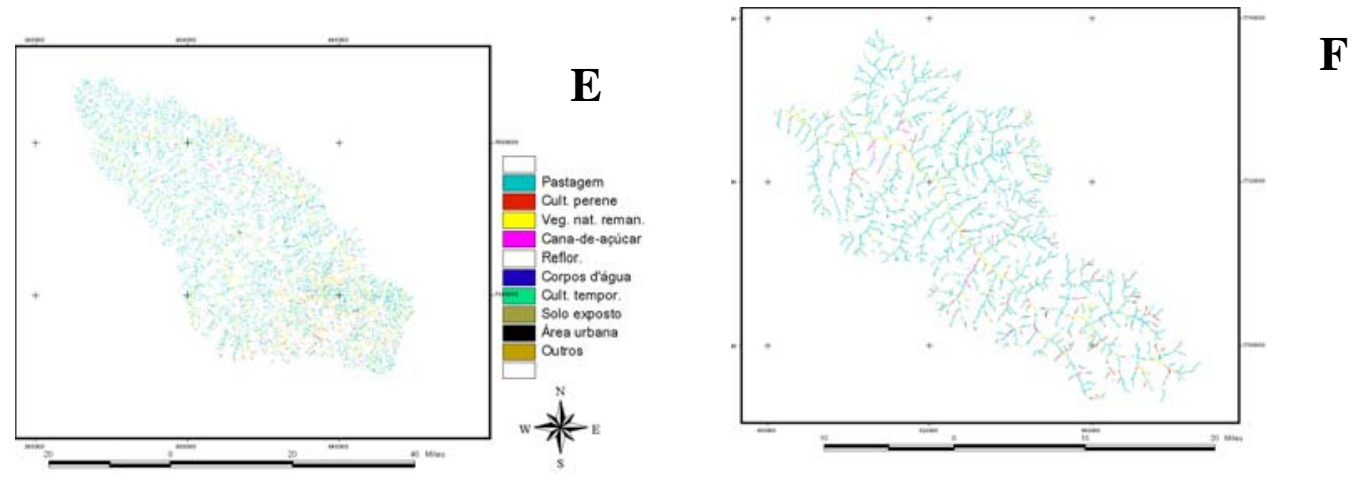

Figura 9 - Mapas dos usos da terra nas zonas tampão das sub-bacias. Em A Paranapanema; B - Apiaí-Guaçu; C - Peixe; D - Taquari; E - Aguapeí e F - São José dos Dourados

A porcentagem da área de cada intervalo de declividade foi calculada para a subbacia (Anexo E) assim como para a zona tampão (Anexo F). Os rios da bacia do Alto Paranapanema apresentaram a maior parte de suas áreas com declividades entre 15\% e 
45\%, porém declividades inferiores a 2\% também são abundantes nestas sub-bacias; outros dois intervalos muito freqüentes foram aqueles entre $5 \%$ a $10 \%$ e entre $10 \%$ a $15 \%$.

Na sub-bacia do rio do Peixe, três intervalos foram igualmente distribuídos. O rio Aguapeí apresentou cinco classes de intervalo com alta participação percentual na subbacia, valores inferiores a $2 \%$ e a faixa entre $5 \%$ a $10 \%$ sendo as mais abundantes. O rio São José dos Dourados apresentou as mesmas classes mais importantes que as encontradas na sub-bacia do rio Aguapeí; entretanto, apenas três classes de intervalo tiveram participação acima de 10\% do terreno (Figura10). 

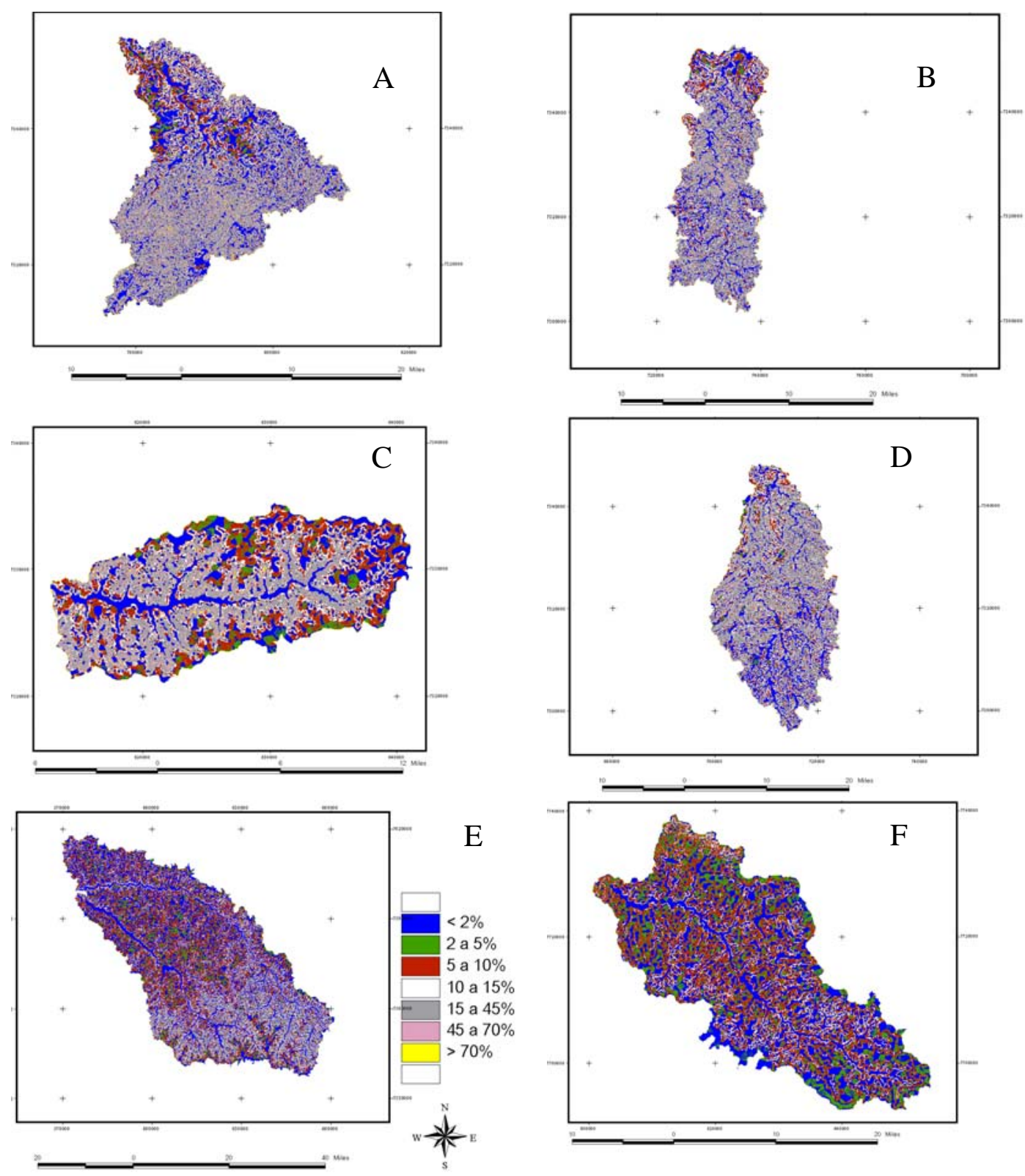

Figura 10 - Classes de declividade em cada sub-bacia. Em A - Paranapanema; B Apiaí-Guaçu; C - Peixe; D - Taquari; E - Aguapeí e F - São José dos Dourados

Ao analisar somente a declividade da área da zona tampão, nota-se um aumento da área de valores inferiores a $2 \%$ em todos os rios. Isto era esperado, uma vez que 
considerou uma área muito próxima ao canal dos rios, as quais geralmente passam pelos locais mais baixos da bacia.

Foram encontrados dois extremos na bacia do Alto Paranapanema, com elevada porcentagem do terreno com declividades entre $15 \%$ a $45 \%$ e também uma grande parte com declividade abaixo de $2 \%$. Nas outras três bacias, há maior participação da declividade abaixo de $2 \%$ e outros intervalos passam a ter participações consideráveis, quando comparadas à bacia do Alto Paranapanema. Os mapas da declividade da área da zona tampão são mostrados na Figura 11. 

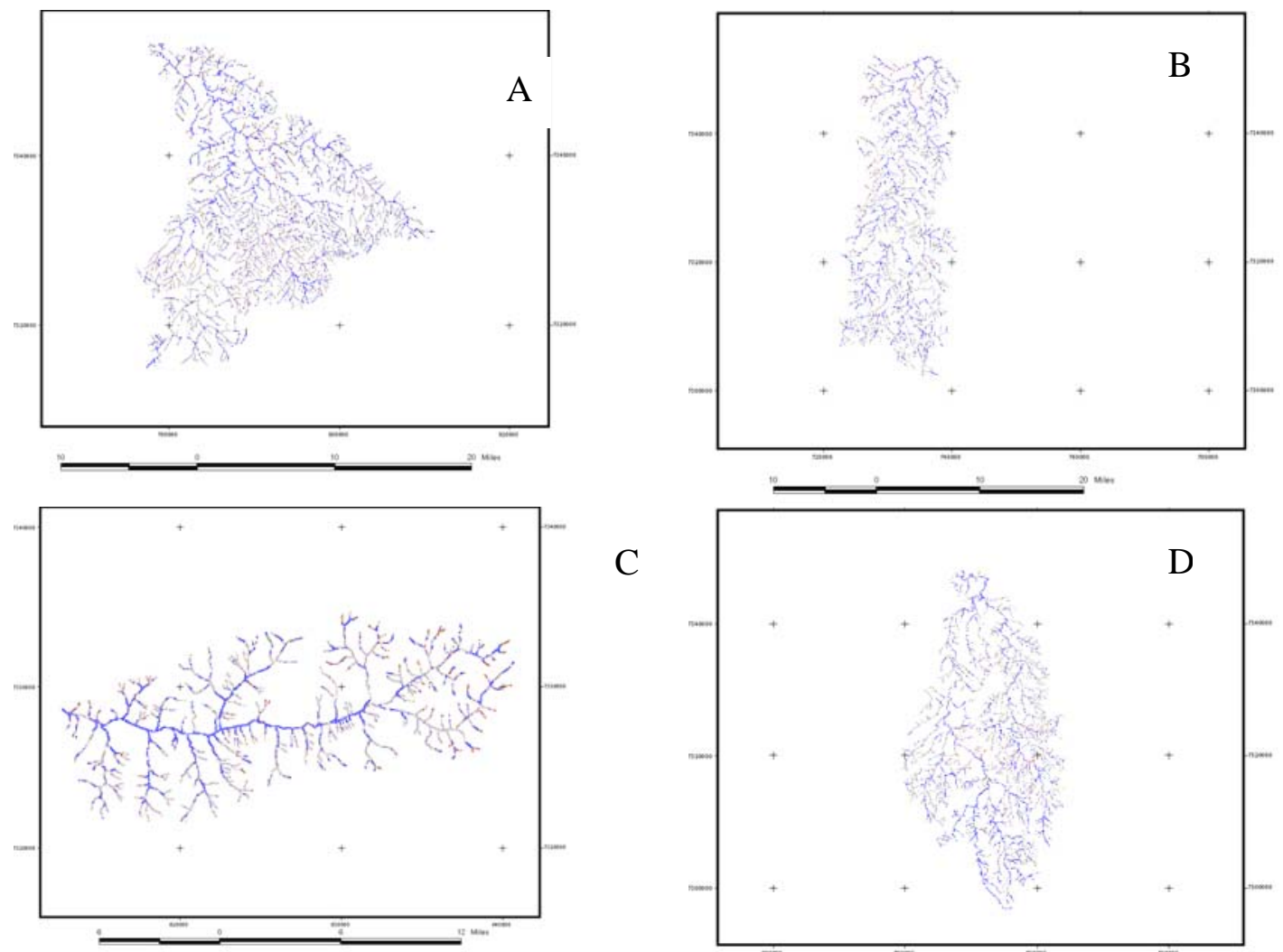

C
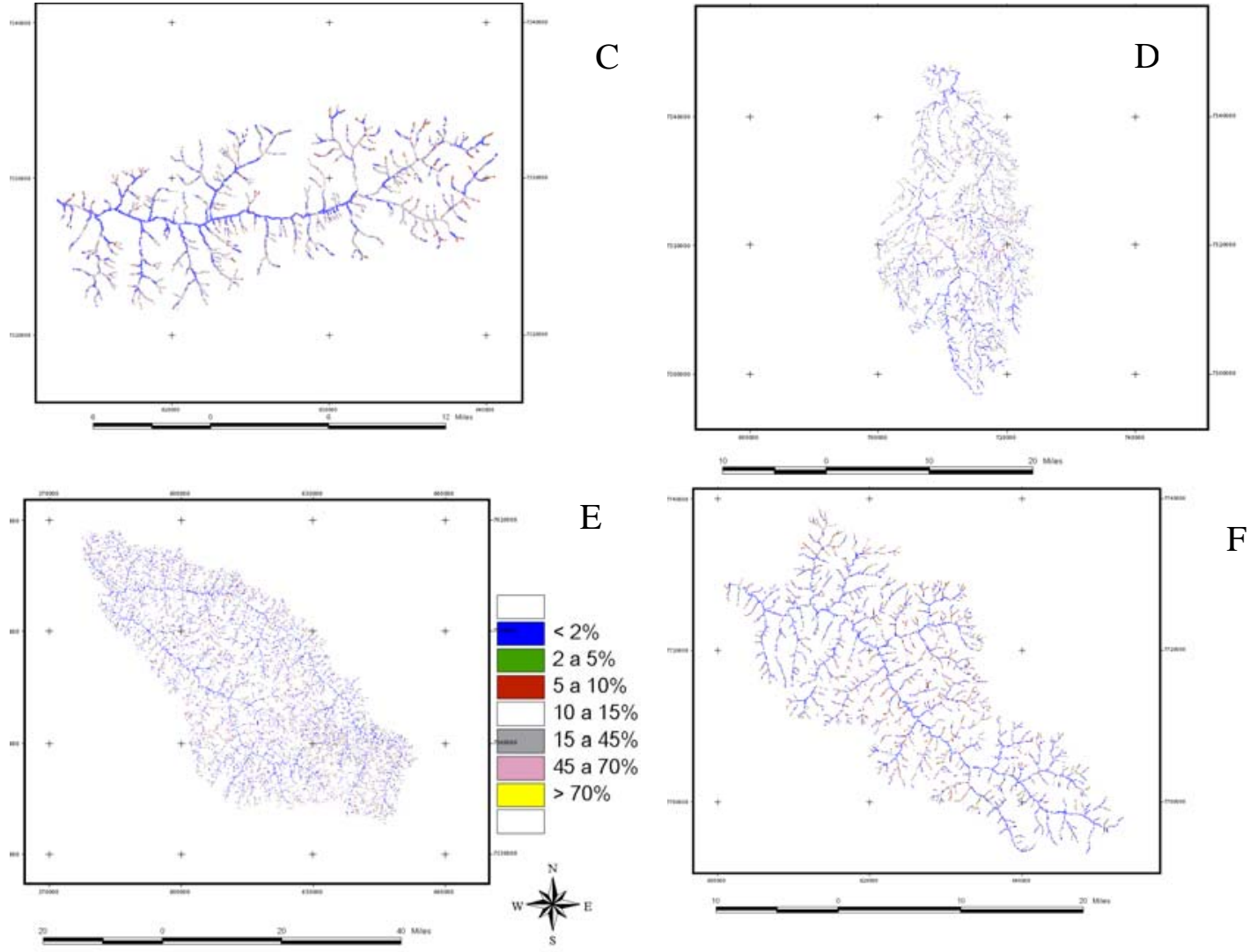

Figura 11 - Intervalos de declividade nas zonas tampão das sub-bacias. Em A Paranapanema; B - Apiaí-Guaçu; C - Peixe; D - Taquari; E - Aguapeí e F - São José dos Dourados

Em relação às variáveis físicas e químicas da água dos rios aqui estudados, Salomão (2004) apresenta uma extensiva discussão sobre as mesmas em sua tese. 
Para o presente estudo, com o intuito de diminuir o número de variáveis apresentadas na Tabela 7, utilizou-se a análise de variância (ANOVA; $\mathrm{p}<0,07$ ) para selecionar aquelas que apresentaram influência sobre os rios. Uma legenda das siglas e abreviaturas utilizadas neste estudo é apresentada na parte pré-textual.

Tabela 9. Valores médios das variáveis químicas e físicas analisadas entre julho e setembro de 2001

\begin{tabular}{|c|c|c|c|c|c|c|}
\hline Variáveis & Paranapanema & $\begin{array}{l}\text { Apiaí- } \\
\text { Guaçu }\end{array}$ & Taquari & Peixe & Aguapeí & $\begin{array}{c}\text { S. J. } \\
\text { Dourados }\end{array}$ \\
\hline FSS (mg sed.L ${ }^{-1}$ ) & 6.0 & 25.4 & 78.5 & 12.1 & 20.0 & 3.2 \\
\hline CSS (mg sed.L $\mathrm{L}^{-1}$ ) & 0.5 & 3.4 & 11.7 & 4.4 & 9.4 & 0.4 \\
\hline TSS (mg sed.L $L^{-1}$ ) & 6.6 & 28.8 & 90.2 & 16.5 & 29.4 & 3.6 \\
\hline Temp. $\left({ }^{\circ} \mathrm{C}\right)$ & 17.4 & 17.8 & 17.8 & 18.9 & 20.0 & 20.8 \\
\hline $\mathrm{pH}$ & 6.3 & 7.3 & 7.3 & 7.6 & 7.5 & 7.4 \\
\hline Cond. $\left(\mu\right.$ S.cm $\left.{ }^{-1}\right)$ & 29.3 & 78.8 & 109.0 & 159.2 & 115.1 & 145.9 \\
\hline OD (\%) & 91.2 & 95.9 & 91.7 & 97.7 & 93.6 & 93.4 \\
\hline DOC $\left(\mathrm{mg} \mathrm{L}^{-1}\right)$ & 6.1 & 5.7 & 4.1 & 3.5 & 2.9 & 2.8 \\
\hline DIC (mg.L $\left.L^{-1}\right)$ & 6.3 & 31.8 & 39.2 & 69.5 & 45.2 & 48.1 \\
\hline $\mathrm{CO}_{2}$ livre $(\mu \mathrm{M})$ & 65.9 & 92.4 & 103.5 & 100.1 & 76.9 & 94.5 \\
\hline $\mathrm{Cl}(\mu \mathrm{M})$ & 102.7 & 62.3 & 59.7 & 70.3 & 108.4 & 261.0 \\
\hline $\mathrm{NO}_{2}(\mu \mathrm{M})$ & 0.0 & 22.8 & 24.4 & 35.7 & 27.9 & 25.8 \\
\hline $\mathrm{NO}_{3}(\mu \mathrm{M})$ & 29.9 & 16.5 & 35.1 & 55.9 & 76.1 & 98.5 \\
\hline $\mathrm{SO}_{4}(\mu \mathrm{M})$ & 9.3 & 12.0 & 78.2 & 13.4 & 13.1 & 44.4 \\
\hline $\mathrm{Na}(\mu \mathrm{M})$ & 102.5 & 98.9 & 221.8 & 90.3 & 160.3 & 359.1 \\
\hline $\mathrm{NH}_{4}(\mu \mathrm{M})$ & 0.3 & 0.3 & 0.3 & 0.4 & 0.5 & 0.0 \\
\hline $\mathrm{K}(\mu \mathrm{M})$ & 13.9 & 38.2 & 54.2 & 64.5 & 93.8 & 102.9 \\
\hline $\mathrm{Mg}(\mu \mathrm{M})$ & 34.2 & 125.4 & 153.4 & 196.4 & 134.7 & 161.0 \\
\hline $\mathrm{Ca}(\mu \mathrm{M})$ & 32.8 & 195.1 & 257.0 & 566.1 & 337.7 & 337.8 \\
\hline Areia (\%) & 94 & - & - & 96,8 & 74 & 90,8 \\
\hline Silte (\%) & 2 & - & - & 2 & 15,6 & 4 \\
\hline Argila (\%) & 4 & - & - & 1,2 & 10,4 & 5,2 \\
\hline
\end{tabular}

\subsubsection{Análises Estatísticas}

Para as análises estatísticas foram utilizados os táxons dominantes na maioria dos ambientes. Seis famílias foram consideradas: Elmidae, Chironomidae, Simuliidae, Leptohyphidae, Leptophlebiidae e Hydropsychidae. Dentre os gêneros, aqueles que se destacaram foram Beardius spp., Polypedilum (Polypedilum) spp., Rheotanytarsus spp., 
Corynoneura spp., Lopescladius spp., Nanocladius spp. e Ablabesmyia spp. As análises de correspondência entre as variáveis ambientais e os rios são expostas em Anexos (G a L).

A Figura 12 apresenta os quatro grupos formados ao analisar a relação entre os rios e as famílias, através da análise de correspondência. Os rios Aguapeí, Paranapanema e Apiaí-Guaçu apresentaram maior relação com Chironomidae e Simuliidae. Com exceção do rio Aguapeí que foi caracterizado pela presença de grandes áreas de pastagem no entorno, além de ter grande influência de $\mathrm{NO}_{3}$ e $\mathrm{K}$ nas suas águas e declividades pouco elevadas na região estudada; os rios Paranapanema e Apiaí-Guaçu tiveram a vegetação natural remanescente como o uso da terra predominante.

Ainda, o rio Apiaí-Guaçu apresentou neste trecho, sofrer elevada influência de muitas variáveis químicas e físicas em suas águas.

Assim como ocorreu com os outros dois rios da bacia do Alto Paranapanema, a vegetação natural remanescente foi característica do rio Taquari. Nesse rio, a família Hydropsychidae foi a que apresentou maior correspondência com o local, cujas águas apresentaram elevada influência de $\mathrm{SO}_{4}$.

O rio do Peixe apresentou relação estreita com Elmidae e o uso do solo em sua bacia foi determinado pelas culturas perenes. As variáveis que influenciaram em suas águas foram Ca e carbono inorgânico dissolvido (DIC).

A pastagem associada a terrenos mais planos caracterizou a paisagem do entorno do rio São José dos Dourados. Naquelas águas, o $\mathrm{NO}_{3}$ foi determinante e as famílias mais abundantes foram Leptohyphidae e Leptophlebiidae, pertencentes aos Trichoptera. 


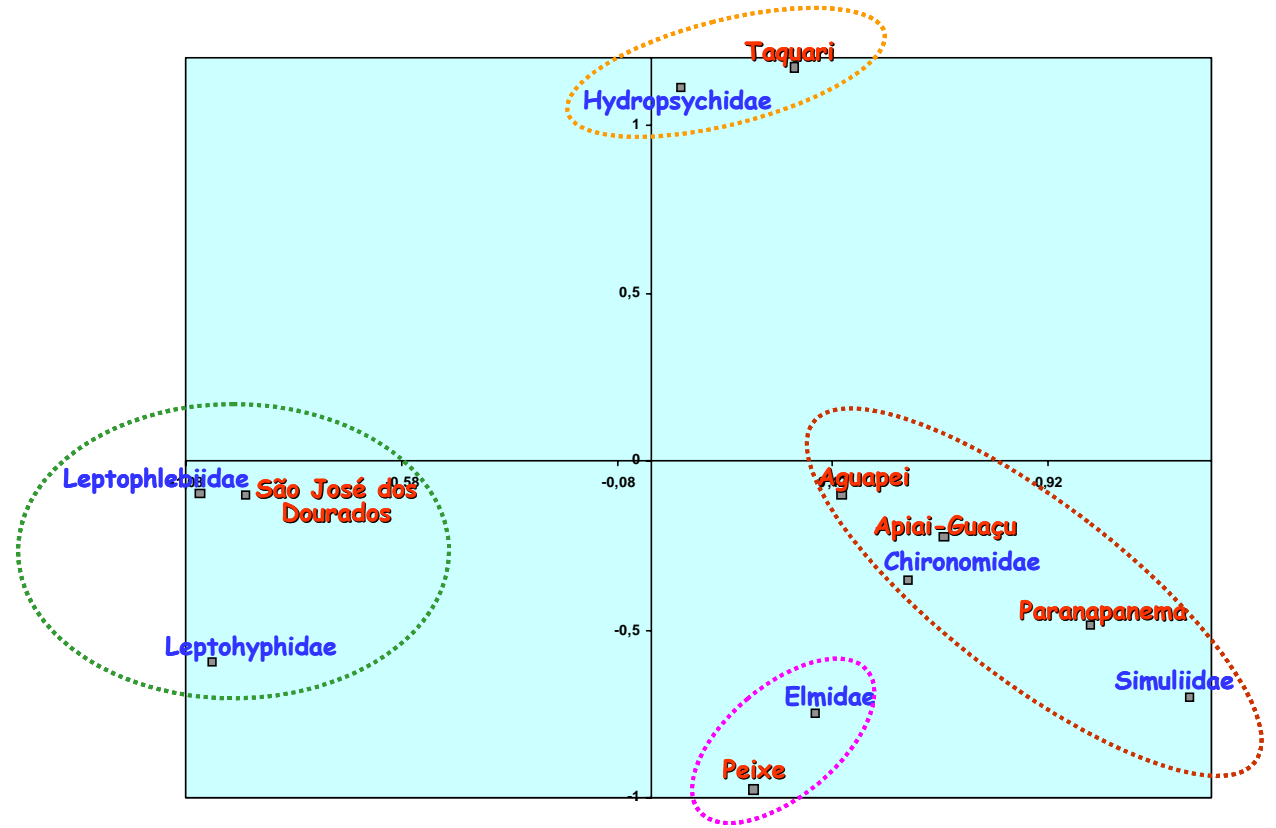

\% de explicação dimensão 1 = 53\%; $\%$ de explicação dimensão $2=37 \%$.

Figura 12 - Relação entre as famílias mais abundantes e os rios estudados, pela análise de correspondência

Ao analisar os rios em função dos gêneros, um quadro bastante semelhante ao acima foi obtido, com a formação de quatro grupos distintos (Figura 13). A diferença entre os grupos ficou por conta da exclusão do rio Apiaí-Guaçu e inclusão do rio Taquari. 


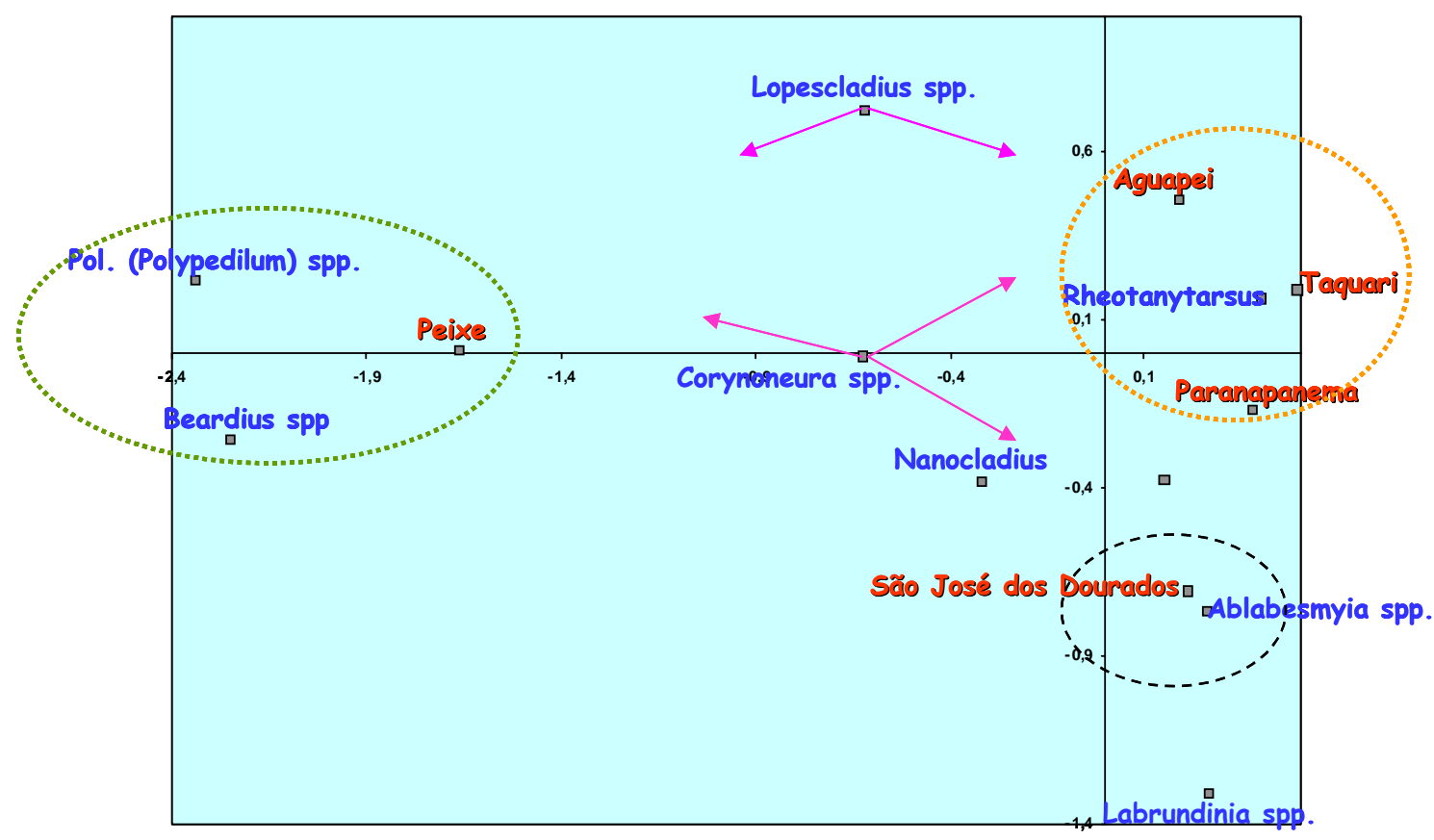

\% de explicação dimensão $1=65 \%$; $\%$ de explicação dimensão $2=17 \%$.

Figura 13 - Análise de correspondência dos gêneros principais e os rios estudados

Dentre os fatores para caracterizar os rios e seus entornos, o uso do solo foi aquele que melhor explicou essa distribuição das famílias em relação aos rios.

A declividade do terreno foi capaz de caracterizar uma parte dos rios. Os rios São José dos Dourados e Aguapeí apresentaram maiores relações com intervalos de declividade de valores mais baixos. Já os rios Taquari e Apiaí-Guaçu tiveram influências mais significativas de locais de maior declividade. A formação destes dois grupos está de acordo com a localização das bacias hidrográficas no interior do estado. Em locais mais planos estão os rios Aguapeí e São José dos Dourados; por outro lado, regiões de relevo mais acidentado circundam os rios Taquari e Apiaí-Guaçu. Os rios Paranapanema e do Peixe não apresentaram relação com qualquer intervalo de declividade considerado.

As variáveis físicas e químicas da água, quando analisadas em função dos rios, ilustram as diferenças inerentes a cada ambiente, caracterizando-os isoladamente.

Desta forma, o rio Paranapanema apresentou estreita relação com o íon cloreto. O rio São José dos Dourados apresentou influência significativa de $\mathrm{NO}_{3}$; esta variável, 
juntamente com o potássio, influenciou significativamente nos resultados para o rio Aguapeí. O rio do Peixe, por sua vez, foi caracterizado pela quantidade de cálcio e carbono inorgânico dissolvido (DIC). O rio Taquari apresentou relação significativa com $\mathrm{SO}_{4}$. Já o rio Apiaí-Guaçu apresentou influência significativa de uma gama de variáveis físicas e químicas da água.

\subsection{Estudo em Escala Local}

\subsubsection{Insetos Aquáticos}

Neste estudo, dos 18 cestos com substrato artificial deixados nos rios para colonização, 15 da pastagem e nove de mata foram retirados do rio São José dos Dourados, enquanto que doze de cada uso da terra foram retirados do rio Aguapeí.

A Tabela 8 apresenta a listagem das famílias de Insecta provenientes dos locais com mata ripária. Poucos táxons foram dominantes nestes rios. No rio Aguapeí apenas Chironomidae dominaram numericamente, contando com 50,3\% do total de insetos. No rio São José dos Dourados, três famílias foram dominantes, Chironomidae (37,3\%), Leptohyphidae (25,3\%) e Leptophlebiidae (12,2\%).

Tabela 10. Famílias amostradas nos trechos de mata, em número total de indivíduos

\begin{tabular}{lcc}
\hline Táxon & Aguapeí & São José dos Dourados \\
\hline Coleoptera & & \\
Dytiscidae & 4 & 21 \\
Elmidae & 116 & 36 \\
Haliplidae & 6 & 16 \\
Diptera & & \\
Ceratopogonidae & 85 & 12 \\
Chironomidae & 593 & 359 \\
Culicidae & 1 & 0 \\
Empididae & 0 & 1 \\
Ephydridae & 6 & 0 \\
Simuliidae & 55 & 0 \\
Tipulidae & 5 & 1 \\
Ephemeroptera & & 5 \\
Baetidae & 21 &
\end{tabular}


Tabela 11. Famílias amostradas nos trechos de mata, em número total de indivíduos

\begin{tabular}{lcc}
\hline Táxon & Aguapeí & São José dos Dourados \\
\hline Caenidae & 5 & 11 \\
Leptohyphidae & 100 & 243 \\
Leptophlebiidae & 28 & 117 \\
Oligoneuridae & 6 & 0 \\
Hemiptera & & \\
Naucoridae & 9 & 19 \\
Lepidoptera & 0 & 0 \\
Pyralidae & 0 & 1 \\
Megaloptera & & \\
Corydalidae & 0 & 1 \\
Odonata & & \\
Calopterygidae & 5 & 4 \\
Coenagrionidae & 0 & 4 \\
Gomphidae & 5 & 0 \\
Libellulidae & 1 & 1 \\
Protoneuridae & 9 & 0 \\
Odonata tipo 1 & 1 & 0 \\
Plecoptera & & \\
Perlidae & 2 & 0 \\
Trichoptera & & 0 \\
Glossossomatidae & 1 & 0 \\
Hydropsychidae & 91 & \\
Hydroptilidae & 2 & \\
Odontoceridae & 1 & \\
Philopotamidae & 0 & \\
Polycentropodidae & 21 & \\
\hline
\end{tabular}

Ainda analisando a mesma Tabela, verifica-se que muitos táxons foram encontrados em somente um dos ambientes. No rio Aguapeí dez famílias foram exclusivas enquanto que no rio São José dos Dourados, apenas cinco famílias foram exclusivas ao local.

Por outro lado, sensíveis são as diferenças observadas nas comunidades provenientes das áreas de pastagem. Duas famílias foram dominantes numericamente no rio Aguapeí, Chironomidae (46,0\%) e Hydropsychidae (21,7\%). No rio São José dos 
Dourados, além de Chironomidae (20,3\%) e Hydropsychidae (18,0\%), Leptohyphidae (27,0\%) e Leptophlebiidae (19,9\%) também foram abundantes (Tabela 9).

Tabela 12. Famílias amostradas nos locais de pastagem, em número total de indivíduos

Táxon

Coleoptera

Dytiscidae

Elmidae

Haliplidae

Hydraenidae

Noteridae

Psephenidae

Ptilodactilidae

Diptera

Ceratopogonidae

Chironomidae

Empididae

Ephydridae

Simuliidae

Tipulidae

Ephemeroptera

Baetidae

Caenidae

Leptohyphidae

Leptophlebiidae

Oligoneuridae

Hemiptera

Naucoridae

Lepidoptera

Pyralidae

Megaloptera

Corydalidae

Odonata

Calopterygidae

Coenagrionidae

Corduliidae

Gomphidae

Libellulidae
Aguapeí

São José dos Dourados

$\begin{array}{cc}4 & 22 \\ 75 & 87 \\ 23 & 34 \\ 4 & 0 \\ 0 & 1 \\ 0 & 3 \\ 1 & 0\end{array}$

77

30

2.039

2.173

1

16

8

0

166

1

1

0

94

43

20

2

423

2.890

355

2.122

58

0

26

220

1

2

2

7

12

34

$8 \quad 56$

$3 \quad 0$

04

1213 
Tabela 13. Famílias amostradas nos locais de pastagem, em número total de indivíduos

\begin{tabular}{lcc}
\hline Táxon & Aguapeí & São José dos Dourados \\
\hline $\begin{array}{l}\text { Protoneuridae } \\
\text { Plecoptera }\end{array}$ & 0 & 1 \\
Perlidae & 25 & 1 \\
Trichoptera & & \\
Glossossomatidae & 6 & 0 \\
Hydropsychidae & 962 & 1.929 \\
Hydroptilidae & 5 & 2 \\
Leptoceridae & 0 & 7 \\
Philopotamidae & 2 & 920 \\
Polycentropodidae & 27 & 75 \\
\hline
\end{tabular}

Assim como as comunidades provenientes dos trechos de mata, as comunidades de pastagem também apresentaram táxons exclusivos a apenas um dos rios. Em ambos os rios, sete famílias foram exclusivas a cada sistema. Ressalta-se que apesar de apresentarem espécimes em ambos locais, a diferença no número de espécimens de Philopotamidae foi exorbitante, com 920 indivíduos coletados no rio São José dos Dourados e apenas dois no rio Aguapeí. O mesmo aconteceu com Simuliidae, que apresentaram 166 indivíduos no rio Aguapeí e um no rio São José dos Dourados.

Ao analisar as comunidades dos dois usos da terra concomitantemente, nota-se evidente dominância de Chironomidae nas amostras de mata e pasto do rio Aguapeí. E mais, Hydropsychidae mostraram-se bastante expressivos na pastagem. Já nas amostras do rio São José dos Dourados, a dominância fica por conta de Leptohyphidae e Chironomidae na mata e, no pasto, além destes dois táxons, Leptophlebiidae e Hydropsychidae também assumem grande participação na comunidade.

A diferença entre as amostras de mata e de pastagem também é evidenciada no número de famílias restritas aos locais. Seis famílias foram exclusivas às amostras de pastagem (Hydraenidae, Noteridae, Psephenidae, Ptilodactilidae, Corduliidae e Leptoceridae) e apenas duas foram exclusivas aos locais de mata (Culicidae e Odontoceridae).

Apesar do índice de diversidade das comunidades de mata e pasto dos rios Aguapeí e São José dos Dourados serem bastante semelhantes, a riqueza taxonômica foi 
maior no rio Aguapeí. Entretanto, os baixos valores da uniformidade evidenciaram o desequilíbrio na distribuição dos indivíduos nas famílias. O índice EPT apresentou valores elevados e semelhantes para todos os usos da terra de ambos os rios, exceto para a mata do rio São José dos Dourados, que apresentou valores bastante baixos (Tabela $10)$.

Tabela 14. Valores dos índices comunitários das famílias amostradas nos trechos de mata ripária e pastagem

\begin{tabular}{lcccc}
\hline & \multicolumn{2}{c}{ Mata } & \multicolumn{2}{c}{ Pastagem } \\
\hline & Aguapeí & S. J. Dourados & Aguapeí & S. J. Dourados \\
Diversidade & 0,9 & 0,8 & 0,8 & 0,8 \\
Riqueza & 8,6 & 6,5 & 7,7 & 6,7 \\
Uniformidade & 0,6 & 0,6 & 0,5 & 0,5 \\
EPT & 10 & 6 & 10 & 10 \\
\hline
\end{tabular}

Ao analisar a fauna amostrada na mata em nível genérico, nota-se, que na mata, a dominância foi de Rheotanytarsus spp. e Lopescladius spp. no rio Aguapeí e Ablabesmyia spp. e Nanocladius spp. no rio São José dos Dourados. Da mesma forma, alguns táxons foram encontrados em apenas um dos rios, como é o caso de Chironomus spp. e Goeldichironomus spp. coletados no rio São José dos Dourados e Cryptochironomus spp. amostrados no rio Aguapeí (Tabela 11).

Tabela 15. Gêneros de Chironomidae, em número total de indivíduos, provenientes dos trechos com mata ripária

\begin{tabular}{lcc}
\hline \multicolumn{1}{c}{ Aguapeí } & São José dos Dourados \\
\hline Táxons & & \\
Chironominae & & \\
Chironomini & 0 & 13 \\
Chironomus spp. & 29 & 0 \\
Cryptochironomus spp. & 0 & 1 \\
Dicrotendipes spp. & 2 & 1 \\
Fissimentum spp. & 0 & 15 \\
Goeldichironomus spp. & 0 & 1 \\
Harnischia spp. & 0 & 6 \\
Lauterborniella spp. & 4 & 3 \\
Parachironomus spp. & &
\end{tabular}


Tabela 16. Gêneros de Chironomidae, em número total de indivíduos, provenientes dos trechos com mata ripária

\begin{tabular}{|c|c|c|}
\hline & Aguapeí & São José dos Dourados \\
\hline \multicolumn{3}{|l|}{ Táxons } \\
\hline \multicolumn{3}{|l|}{ Chironominae } \\
\hline \multicolumn{3}{|l|}{ Chironomini } \\
\hline Pol. (Polypedilum) spp. & 12 & 1 \\
\hline Zavreliella spp. & 3 & 3 \\
\hline \multicolumn{3}{|l|}{ Pseudochironomini } \\
\hline Pseudochironomus spp. & 18 & 0 \\
\hline \multicolumn{3}{|l|}{ Tanytarsini } \\
\hline Rheotanytarsus spp. & 301 & 45 \\
\hline Morfotipo O & 0 & 41 \\
\hline \multicolumn{3}{|l|}{ Orthocladiinae } \\
\hline \multicolumn{3}{|l|}{ Corynoneurini } \\
\hline Corynoneura spp. & 27 & 12 \\
\hline \multicolumn{3}{|l|}{ Orthocladiini } \\
\hline Lopescladius spp. & 158 & 4 \\
\hline Nanocladius spp. & 53 & 75 \\
\hline \multirow{2}{*}{\multicolumn{3}{|c|}{$\begin{array}{l}\text { Tanypodinae } \\
\text { Coelotanypodini }\end{array}$}} \\
\hline & & \\
\hline Coelotanypus spp. & 0 & 1 \\
\hline \multicolumn{3}{|l|}{ Pentaneurini } \\
\hline Ablabesmyia spp. & 50 & 146 \\
\hline Denopelopia spp. & 2 & 0 \\
\hline Labrundinia spp. & 6 & 11 \\
\hline Larsia spp. & 9 & 4 \\
\hline Pentaneura spp. & 10 & 0 \\
\hline \multicolumn{3}{|l|}{ Procladiini } \\
\hline Djalmabatista spp. & 1 & 6 \\
\hline
\end{tabular}

Em relação aos gêneros de Chironomidae provenientes das amostras de pastagem, Rheotanytarsus spp. e Nanocladius spp. dominaram as comunidades de ambos os rios, com, 57,2\% e 14,2\% dos indivíduos do rio Aguapeí e 48,3\% e 19,4\%, do rio São José dos Dourados, respectivamente (Tabela 12). 
Tabela 17. Táxons de Chironomidae amostrados nos trechos de pastagem de ambos os rios, em número absoluto de indivíduos

\begin{tabular}{|c|c|c|}
\hline & Aguapeí & São José dos Dourados \\
\hline \multicolumn{3}{|l|}{ Táxons } \\
\hline \multicolumn{3}{|l|}{ Chironominae } \\
\hline \multicolumn{3}{|l|}{ Chironomini } \\
\hline Beardius spp. & 2 & 4 \\
\hline Chironomus spp. & 0 & 26 \\
\hline Cryptochironomus spp. & 25 & 0 \\
\hline Endotribelos spp. & 9 & 1 \\
\hline Fissimentum spp. & 0 & 1 \\
\hline Lauterborniella spp. & 0 & 11 \\
\hline Parachironomus spp. & 4 & 10 \\
\hline Pol. (Asheum) spp. & 0 & 1 \\
\hline Pol. (Polypedilum) spp. & 12 & 12 \\
\hline Stenochironomus spp. & 5 & 5 \\
\hline Zavreliella spp. & 17 & 1 \\
\hline Morfotipo M & 14 & 0 \\
\hline Morfotipo Y & 1 & 0 \\
\hline \multicolumn{3}{|l|}{ Tanytarsini } \\
\hline Rheotanytarsus spp. & 1.123 & 956 \\
\hline Morfotipo O & 0 & 170 \\
\hline \multicolumn{3}{|l|}{ Orthocladiinae } \\
\hline \multicolumn{3}{|l|}{ Corynoneurini } \\
\hline Corynoneura spp. & 170 & 156 \\
\hline \multicolumn{3}{|l|}{ Orthocladiini } \\
\hline Lopescladius spp. & 170 & 8 \\
\hline Nanocladius spp. & 279 & 383 \\
\hline \multirow{2}{*}{\multicolumn{3}{|c|}{$\begin{array}{l}\text { Tanypodinae } \\
\text { Coelotanypodini }\end{array}$}} \\
\hline & & \\
\hline $\begin{array}{l}\text { Coelotanypus spp. } \\
\text { Pentaneurini }\end{array}$ & 0 & 2 \\
\hline Ablabesmyia spp. & 161 & 325 \\
\hline Denopelopia spp. & 0 & 2 \\
\hline Labrundinia spp. & 23 & 81 \\
\hline Larsia spp. & 8 & 14 \\
\hline $\begin{array}{l}\text { Pentaneura spp. } \\
\text { Procladiini }\end{array}$ & 16 & 3 \\
\hline Djalmabatista spp. & 0 & 1 \\
\hline
\end{tabular}


Em relação aos índices comunitários, o índice de diversidade apresentou maiores valores para as faunas provenientes da mata, independentemente do rio. A uniformidade, por estar intimamente relacionada com a diversidade, seguiu esta tendência. Por outro lado, o rio São José dos Dourados contou com maior riqueza taxonômica para as comunidades dos dois tipos de usos do solo. Além disso, a riqueza foi discretamente maior para as comunidades amostradas nos trechos com mata ripária (Tabela 13).

Tabela 18. Valores dos índices comunitários das comunidades de cada uso da terra e rio

\begin{tabular}{lcccc}
\hline & \multicolumn{2}{c}{ Pastagem } & \multicolumn{2}{c}{ Mata } \\
\hline & Aguapeí & S. J. Dourados & Aguapeí & S. J. Dourados \\
Diversidade & 0,7 & 0,7 & 0,8 & 0,9 \\
Riqueza & 4,8 & 6,3 & 5,3 & 6,9 \\
Uniformidade & 0,5 & 0,6 & 0,6 & 0,7 \\
\hline
\end{tabular}

\subsubsection{Análises Estatísticas}

Neste estudo apenas os dados dos gêneros de Chironomidae foram analisados estatisticamente em função dos usos do solo. Para avaliar esta relação entre os gêneros e os tipos de usos do solo considerados, utilizou-se a análise de variância (ANOVA). A influência significativa na abundância e riqueza pelo uso da terra foi confirmada por este teste; cujo valor para as variáveis é mostrado na Tabela 14 .

Tabela 19. Valor da ANOVA (r) e significância para as variáveis dependentes de acordo com os três fatores analisados. Valores significantes são marcados com asteriscos

\begin{tabular}{lcccccc}
\hline & \multicolumn{2}{c}{ Uso da terra (pasto) } & \multicolumn{2}{c}{ Rio (Aguapeí) } & \multicolumn{2}{c}{$\begin{array}{c}\text { Interação (uso da } \\
\text { terra X rio) }\end{array}$} \\
\cline { 2 - 7 } & $\mathrm{r}$ & $\mathrm{p}$ & $\mathrm{r}$ & $\mathrm{p}$ & Valor $P$ & $\mathrm{p}$ \\
\hline Total de indivíduos & $0.003^{* *}$ & 0.880 & 0.923 & 0.051 & 0.144 & 0.308 \\
Riqueza & $0.023^{*}$ & 0.632 & 0.360 & 0.148 & 0.522 & 0.097 \\
Rheotanytarsus spp. & $0.001 * *$ & 0.932 & 0.163 & 0.284 & 0.213 & 0.236 \\
Nanocladius spp. & $0.004^{*}$ & 0.837 & 0.066 & 0.454 & 0.964 & 0.050 \\
Corynoneura spp. & $0.005^{*}$ & 0.815 & 0.513 & 0.099 & 0.281 & 0.188
\end{tabular}


Tabela 20. Valor da ANOVA (r) e significância para as variáveis dependentes de acordo com os três fatores analisados. Valores significantes são marcados com asteriscos

\begin{tabular}{lcccccc}
\hline & \multicolumn{2}{c}{ Uso da terra (pasto) } & \multicolumn{2}{c}{ Rio (Aguapeí) } & \multicolumn{2}{c}{$\begin{array}{c}\text { Interação (uso da } \\
\text { terra X rio) }\end{array}$} \\
\cline { 2 - 7 } & $\mathrm{r}$ & $\mathrm{p}$ & $\mathrm{r}$ & $\mathrm{p}$ & Valor $P$ & $\mathrm{p}$ \\
\hline Lopescladius spp. & 0.894 & 0.052 & $0.001 * *$ & 0.954 & 0.884 & 0.052 \\
Coletores & $0.008 * *$ & 0.780 & 0.161 & 0.286 & 0.703 & 0.066 \\
Filtradores & $0.000 * * *$ & 0.960 & 0.971 & 0.050 & 0.671 & 0.070 \\
Predadores & $0.000 * * *$ & 0.986 & 0.798 & 0.057 & $0.048 *$ & 0.511 \\
Picadores & $0.004 * *$ & 0.846 & 0.242 & 0.213 & 0.242 & 0.213 \\
Raspadores & $0.025 *$ & 0.621 & 0.663 & 0.071 & 0.663 & 0.071 \\
\hline
\end{tabular}

$*<0.05 ; * *<0.01 ; * * *<0.001$

Dentre os tipos de usos da terra, a pastagem mostrou maior valor na abundância de indivíduos que a mata para a maioria das variáveis dependentes analisadas. Estes resultados são melhor vistos nas Figuras 14 e 15.

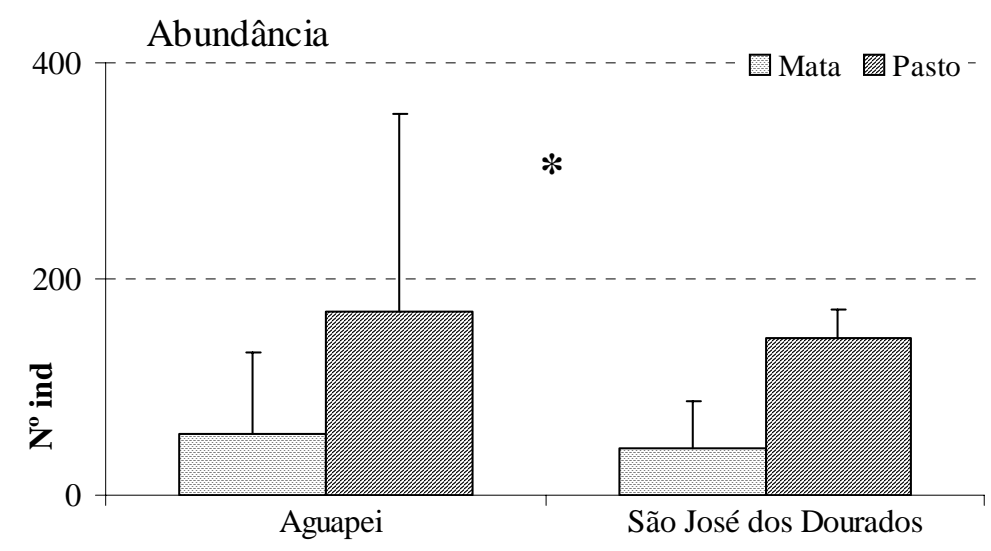

Figura 14 - Número total de Chironomidae relacionado ao uso da terra em cada rio. Asterisco marca a influência da pastagem

Rheotanytarsus spp., Nanocladius spp. e Corynoneura spp. tiveram influência significativa do uso da terra, determinando a distribuição da família. Por outro lado, 
Lopescladius pp., também dominantes, não apresentaram relação com o uso/cobertura da terra.
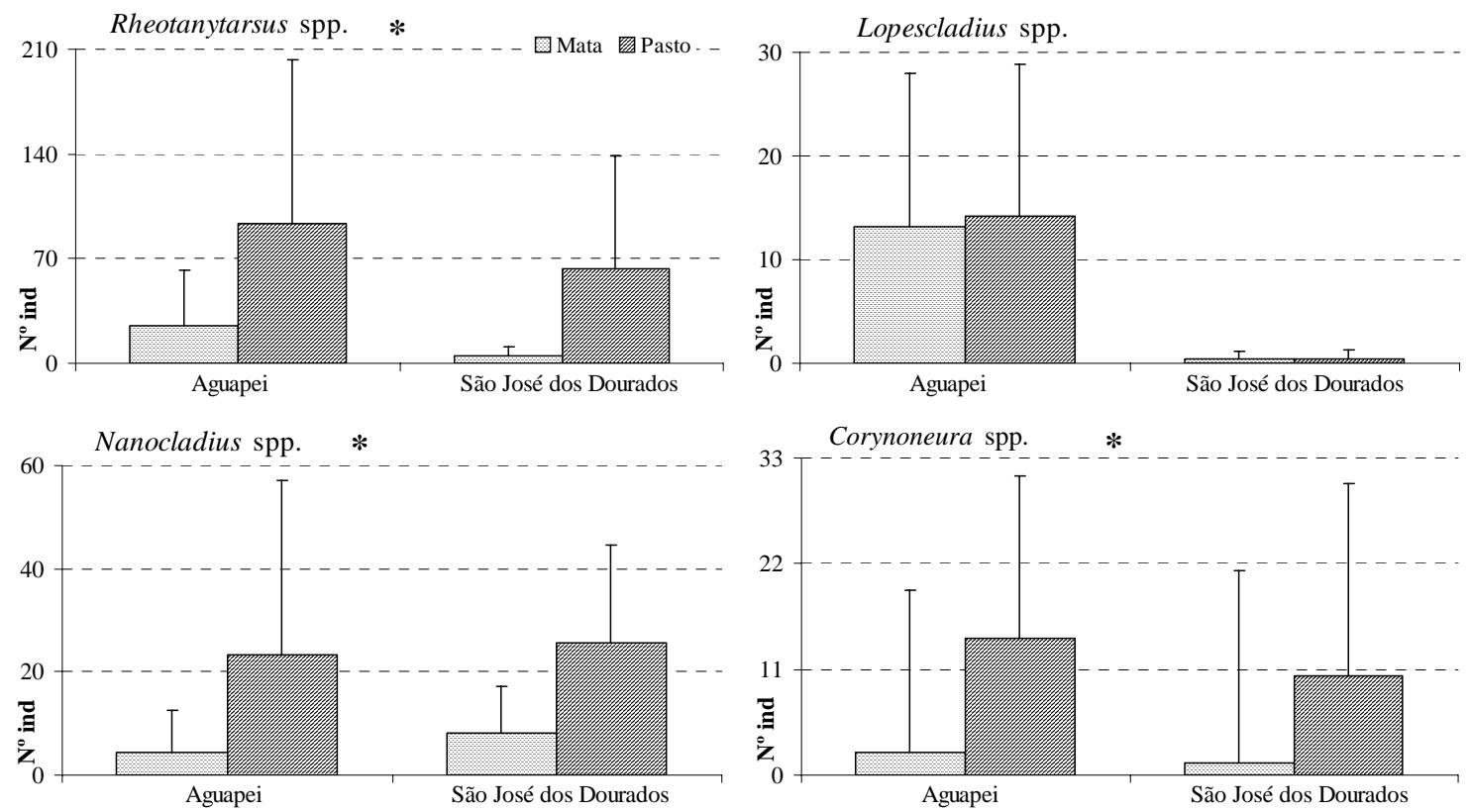

Figura 15 - Distribuição dos quatro gêneros mais abundantes em cada uso da terra por rio. Asteriscos marcam a influência da pastagem 


\section{DISCUSSÃO}

\subsection{Estudo em Escala Regional}

A proposta de avaliar o grau de degradação ambiental em função da ocupação humana em bacias hidrográficas do Estado de São Paulo foi uma iniciativa do Projeto Temático "Estrutura e funcionamento de hidrobacias de meso e micro-escalas do Estado de São Paulo: bases para gerar e sustentar a biodiversidade” (FAPESP N 99/05279-4). Vários estudos sobre diferentes aspectos do ecossistema vinculados a este projeto foram realizados, inclusive este.

No presente estudo, consideam-se as comunidades de insetos aquáticos de rios de grande porte como ferramenta indicativa desta degradação. Estudos conduzidos em rios de médio e grande porte que consideram a entomofauna aquática são pouco numerosos na literatura local e mundial (Karr et al., 2000; Soulsby et al., 2001). Isto se deve, em parte, à dificuldade de acesso e amostragem, inerentes a estudos nestes sistemas aquáticos; o que acarreta em elevada demanda de recursos, financeiro e humano.

Das 31 famílias aqui identificadas, seis apresentaram participação percentual acima de $10 \%$ em todos (ou quase) os rios. O número de famílias raras, ou mesmo exclusivas a um local, foi considerável, o que fez com que a riqueza dos locais amostrados fosse elevada.

A bacia do Alto Paranapanema é considerada uma unidade de gerenciamento com alto índice de preservação de suas matas, o que reflete em boa qualidade da água. Entretanto, de forma controversa, os dados referentes às comunidades amostradas nos rios desta bacia apresentaram resultados opostos, ou seja, os rios Paranapanema e Taquari apresentaram os menores valores do índice de riqueza dentre os seis rios, assim como o EPT. O rio Apiaí-Guaçu, apesar de pertencer a esta bacia, apresentou elevados 
valores dos índices comunitários próximos àqueles encontrados para a comunidade proveniente do rio do Peixe.

Chironomidae, em geral, são os mais abundantes numericamente em estudos ecológicos (Aagard et al., 2004; Cranston et al., 1997) e muitas vezes sua dominância é associada à alta degradação ambiental (Brown et al., 1997; Pinel-Alloul et al., 1996). Por outro lado, a ocorrência de representantes de Ephemeroptera é esperada em locais com maior grau de preservação ambiental, aquática e terrestre (Melody \& Richardson, 2004).

Contrariamente ao afirmado pela literatura concernente, no estudo aqui apresentado foi encontrada relação significativa entre Chironomidae e rios da bacia do Alto Paranapanema. Enquanto que o rio São José dos Dourados, cuja bacia hidrográfica está entre as mais degradadas apresentou (neste estudo) relação significativa com duas famílias de Ephemeroptera.

Neste caso, a correlação de Pearson indicou influência significativa de áreas urbanizadas sobre os Chironomidae e influência de solo exposto sobre Leptohyphidae e Leptophlebiidae, as duas famílias de Ephemeroptera consideradas acima. Além disso, essas duas famílias apresentaram também relação negativa com a vegetação natural remanescente. Em estudo realizado por Gerhard (2005), o autor encontrou menor número de espécies e diversidade de peixes em microbacias com predomínio de mata nativa em comparação àquelas com pastagem e cana-de-açúcar.

De maneira geral, as famílias numericamente dominantes apresentaram maior influência do fator uso do solo que da declividade ou das variáveis físicas e químicas da água, evidenciadas através da correlação de Pearson (Anexo B). Dentre os usos do solo, poucas foram as categorias que influenciaram nestes táxons; além disso, a escala utilizada foi pouco determinante nos resultados, com informações sutilmente mais abrangentes ao considerar os usos da terra na zona tampão ao invés da sub-bacia.

Por outro lado, ao examinar a relação dos fatores sobre os índices comunitários, há maior envolvimento de todos os tipos de variáveis. Neste caso, o uso de informações de uso da terra na sub-bacia gerou resultados mais significativos; o mesmo foi observado para os dados da declividade, com exceção de alguns intervalos de declividade em relação ao índice de diversidade. 
Ao analisar as comunidades em nível genérico, a dominância de poucos táxons também foi evidenciada neste nível taxonômico. Os grupos aqui identificados estão em conformidade aos encontrados por Anaya (1997) para o rio do Peixe, principalmente em relação aos gêneros de Chironomidae dominantes.

Neste caso, os índices comunitários não apresentaram as mesmas diferenças que as apontadas acima ao analisar a comunidade em nível de família. Quando avaliadas em nível genérico, as comunidades foram bastante semelhantes, com exceção daquelas provenientes dos rios Taquari e do Peixe. A primeira apresentou as menores riqueza e uniformidade enquanto que aquela do rio do Peixe obteve maior uniformidade na distribuição do número de indivíduos nos táxons.

Estes resultados são contrários ao encontrado por Wright et al. (1995) que analisaram a utilização dos níveis de família e espécie em estudos ecológicos. Os autores observaram o mesmo padrão de resposta utilizando ambos os níveis taxonômicos para avaliar o impacto de efluente de esgoto na comunidade macrobentônica.

De acordo com Karr (1999), não importa o método de coleta dos insetos que for utilizado, mas sim o rigor adotado nos procedimentos de amostragem, seleção de métricas e desenvolvimento de critérios de julgamento. Segundo o autor, se estes procedimentos estiverem corretos, os resultados serão os mesmos com qualquer método amostral usado.

Já Guerold (2000) observou que o uso do nível de família para o cálculo de algumas métricas é perigoso, especialmente ao medir a qualidade da água e mudanças nas comunidades de macroinvertebrados. Para o autor, o uso de níveis taxonômicos maiores subestima o efeito das alterações ambientais.

Em contrapartida, Thorne \& Williams (1997), verificaram que o uso do nível de família para estudos de monitoramento é satisfatório, mas ressaltam que a identificação em nível genérico ou específico é importante por aumentar o número de táxons geral e EPT e, ainda, diminuir uma possível perda da precisão das métricas comunitárias.

Pela correlação de Pearson, os achados, em parte, foram congruentes ao descrito acima. O uso do solo apresentou influência em metade dos táxons, onde aqueles usos característicos de plantas $\mathrm{C}_{3}$ foram predominantes. Por outro lado, a presença de 
vegetação arbórea apresentou influência negativa em dois gêneros. Poucas foram as variáveis físicas e químicas da água e os intervalos de declividade do terreno que apresentaram influência sobre algum gênero.

Quanto aos índices comunitários, a riqueza taxonômica sofreu influência negativa da fração fina dos sólidos suspensos na água (FSS) e do $\mathrm{SO}_{4}$. Os outros dois índices tiveram influência da cultura perene e da cana-de-açúcar, na escala da zona tampão.

Apesar disso, Sandin \& Johnson (2000), em um estudo que analisou a eficácia de dez métricas mais usadas para descrever comunidades de macroinvertebrados, verificaram que a riqueza (de táxons e EPT) foi o melhor índice para indicar uma perturbação no ambiente, enquanto que a densidade de indivíduos foi a métrica que menos contribuiu na aquisição de informações.

Richards et al. (1996) verificaram que a influência de características da cobertura da paisagem na bacia de drenagem pode ser tão importante quanto a vegetação ripária para o entendimento dos ecossistemas de riachos. Ressalta-se que este estudo foi conduzido em regiões de maiores declividades que aquelas encontradas no estudo aqui apresentado. Naqueles locais de elevada declividade, certamente as alterações que ocorrem na bacia serão sentidas nos cursos d’água de maneira muito mais marcante que em regiões mais planas (Vuori \& Joensuu, 1996).

Há incertezas sobre o uso da bacia ou da zona tampão para gerar informações a respeito da qualidade da água. Para Sliva \& Williams (2001), essas dúvidas ocorrem devido à particularidade intrínseca de cada bacia e também ao consumo de tempo e recursos que estudos mais minuciosos requerem para abranger a escala da bacia.

Esses resultados, embora controversos, indicam a necessidade de aprofundamento no nível taxonômico a ser trabalhado. Este fato é importante pela diversidade de hábitos alimentares encontrados nas famílias dos insetos aquáticos, o que pode estar determinando sua ocorrência; este fato também é ressaltado por Cascorbi (2002).

Scarsbrook et al. (2000) reportam resultados conflitantes em seu estudo a respeito do uso de índices comunitários para avaliar a fauna macrobentônica.

Os dados também parecem indicar que o entorno imediato ao local de coleta tem influência muito mais significativa na comunidade ali presente que o entorno geral, em 
escala da zona tampão ou da sub-bacia. Esta hipótese pode ser considerada devido às condições encontradas nos locais de coleta; os rios Paranapanema, Apiaí-Guaçu e Taquari apresentavam pouquíssimas árvores, sendo estas quase ausentes. Já o rio São José dos Dourados, nos trechos de pasto, apresentou um número consideravelmente maior de árvores nos limites da região ripária.

A idéia central defende que não importam as condições gerais de preservação da mata ripária (em termos percentuais ou média de usos da terra) mas que para fornecer condições adequadas de vida aos insetos aquáticos, toda a extensão desta mata deve estar em boas condições de preservação, atestando o código florestal que a designa como Área de Preservação Permanente. Esta maior influência local sobre os macroinvertebrados em comparação a escalas maiores é defendida por autores como Armitage \& Petts (1992); Lammert \& Allan (1999); Murphy \& Giller (2000) e Strayer (2000).

Devido à baixa incidência de representantes de Odonata neste estudo, estes não foram utilizados nas análises estatísticas e pouco se pode falar de sua participação nas comunidades. Porém, um estudo sobre a distribuição desta ordem em paisagens florestadas e urbanas conduzido por Samways \& Steytler (1996), reforça o reconhecimento da importância da manutenção da zona ripária ao longo dos rios.

Os resultados deste estudo não concordam com o encontrado por Salomão (2004), que também participou do Projeto Temático comentado anteriormente. Este autor demonstrou haver uma diminuição na qualidade da água em função do aumento da ocupação humana e conseqüente degradação ambiental em algumas bacias hidrográficas do Estado de São Paulo. A não concordância entre os resultados pode ser em decorrência de que o uso de critérios biológicos é mais compreensivo e robusto que as variáveis químicas, sendo efetivos para diagnosticar a degradação, definindo suas causas (Foy et al., 2001; Karr, 1998; Metcalfe, 1989). Por outro lado, Tomazelli (2003) que analisou a concentração de metais pesados em peixes e bivalves das mesmas bacias hidrográficas, verificou baixa concentração dos mesmos nas bacias do Alto Paranapanema, Aguapeí, Peixe e São José dos Dourados, sem distinção entre os locais. 
Alguns estudos que analisam as interações de diferentes elementos do ecossistema em micro (variáveis da água) e macro-escalas (usos e coberturas do solo) e os macroinvertebrados aquáticos apontam resultados incongruentes e muitas vezes de difícil conclusão. A análise da influência de cada parte do sistema isoladamente sobre a biota apresenta resultados satisfatórios, porém o mesmo não pode ser dito quando se procura avaliar a interação destes fatores, devido à complexidade formada. Isto pode ser visto nos estudos conduzidos por Aguiar et al. (2002) e Hewitt et al. (1998).

A importância em analisar os diversos componentes do ecossistema de forma integrada a fim de fornecer informações que norteiem o manejo dos mesmos é uma prática reconhecida e defendida por diversos autores (Charvet et al., 2000; Chessman \& Williams, 1999; Dumanski \& Pieri, 2000); reforçada pela intensidade das mudanças que o ambiente natural vem sofrendo pela implementação de sistemas agropastoris (Carter, 2001; Fisher, 2000).

Conforme idéia defendida por Küiper (1998), não somente a diversidade de hábitats deve ser considerada ao planejar estratégias de recuperação e manutenção de uma bacia hidrográfica em diferentes níveis de escala. Segundo a autora, a coerência (entre os componentes da paisagem como expressão de relações horizontais entre locais) e a continuidade (relações temporais de uso da terra e organização espacial do passado ao futuro) são critérios fundamentais cujos usos devem ser associados à diversidade para estes planejamentos.

Como pode ser notado, não há um consenso sobre o nível taxonômico a ser utilizado. Para estudos ecológicos, a identificação mais detalhada é uma prática bem vista, pois possibilitaria o reconhecimento de táxons ainda não descritos na literatura, cujas funções ecológicas, conseqüentemente, são obscuras. Para estudos de monitoramento, que apresentam caráter temporal longo e a necessidade de resultados é urgente, a utilização de níveis taxonômicos mais elevados facilita o processo global. Apesar disso, defende-se a utilização do menor nível taxonômico possível mesmo que somente uma família seja objeto de trabalho; sendo seus representantes identificados em níveis mais apurados. 
A generalização de hábitos alimentares deve ser evitada, pois muitas vezes é errônea e pode mascarar categorias funcionais dentro de um mesmo gênero, subestimando-as em tipo e número. Devido a isto, evitou-se neste estudo analisar as comunidades em função das categorias tróficas. Entretanto, as informações fornecidas por esta análise seriam uma ferramenta valiosa no entendimento da influência dos diversos usos da terra na comunidade de insetos aquáticos.

A necessidade do aprofundamento no conhecimento das guildas alimentares e identificação das mesmas é um item importante a ser considerado em novos estudos deste caráter.

Para as bacias hidrográficas aqui estudadas, por apresentarem um contínuo de cada uso da terra em toda a região em torno do curso d’água (ou seja, a atividade ultrapassa os limites da Área de Proteção Permanente, fazendo com que esta apresente as mesmas características de uso da terra que o entorno), a utilização das informações de uso do solo na zona ripária é satisfatória para estudos ecológicos desta natureza. Muito provavelmente, as outras bacias do Estado de São Paulo se encaixam neste panorama, mas certamente é necessário verificar a verossimilhança desta suposição.

Apesar dos dados apresentados não serem conclusivos e mais estudos serem necessários, esta investigação foi importante pela disposição em trabalhar em um ambiente de difícil acesso e manejo, como são os rios da magnitude destes aqui estudados. As informações a respeito dos insetos aquáticos nestes locais são pioneiras e táxons novos foram encontrados, indicando a importância em se considerar estes sistemas nos estudos de diversidade conduzidos no Estado.

Além disso, a oportunidade de avaliar um grande número de variáveis físicas e químicas da água (fato que normalmente não ocorre) foi possível graças ao caráter integrativo de um projeto temático. Como também pela disponibilização dos mapas digitais de uso e cobertura do solo, esforços que não poderiam ser realizados por apenas uma pessoa, em função do tempo disponível e, principalmente, pelo acúmulo de conhecimento sobre as três disciplinas envolvidas, necessário para tal finalidade.

Ainda, deve-se considerar, em estudos futuros, a necessidade de realizar a análise em escala temporal. Como foi constatado aqui, é elevado o número de indivíduos da 
entomofauna aquática destes rios e um estudo que considere um maior número de coletas resultará em diminuição no número de rios analisados conjuntamente, a menos que uma equipe especializada na taxonomia de um ou vários grupos trabalhe de maneia integrada. Este aumento no número de coletas possibilitaria a utilização de outros testes estatísticos e, talvez, a obtenção de maiores conclusões.

\subsection{Estudo em Escala Local}

A realização desta parte do estudo, integrada ao estudo em escala regional de forma concomitante em tempo e local, possibilitou a obtenção de respostas mais conclusivas a respeito da influência do uso do solo (particularmente a presença de mata ripária ao longo dos rios) na comunidade de insetos aquáticos.

Uma vez que o estudo em escala regional demonstrou maior eficácia na avaliação dos dados por meio da utilização do nível genérico, optou-se nesta parte do estudo, utilizar apenas a comunidade de Chironomidae (identificada em nível genérico) para as análises estatísticas. Através desta família, verificou-se a influência positiva da presença da mata ripária no número de indivíduos e riqueza de táxons da mesma.

Vale a pena ressaltar que, aparentemente, é a mata imediatamente adjacente ao rio que fornece melhores condições para que estes animais tenham uma vida adequada, o que resulta em ganho na diversidade local. Desta forma, a manutenção da integridade de todo o corredor de mata ripária é fundamental para a saúde do rio e não somente pequenas áreas do corredor, situação atualmente encontrada nestas bacias hidrográficas do Estado de São Paulo.

A utilização de organismos como peixes e invertebrados em lugar de variáveis químicas e físicas para avaliar a qualidade das águas é uma prática estabelecida mundialmente. Há praticamente uma década, reconheceu-se a importância de analisar a integridade e composição da vegetação ripária e plantas aquáticas (Naiman et al., 1992). E mais recentemente, o uso integrado de vários elementos do ecossistema para a avaliação da água e saúde dos cursos d’água é considerado nos estudos ecológicos.

No presente estudo, verificou-se maior número de famílias amostradas no rio Aguapeí. Apesar das comunidades da pastagem de ambos os rios apresentarem maior 
número de táxons e de indivíduos, o índice de riqueza apreesntou valores bastante próximos para os usos da terra coincidentes, assim como para cada rio, com maiores valores para as comunidades do rio Aguapeí.

Contudo, ao analisar a quantidade de gêneros amostrados, nota-se uma maior semelhança nos valores entre os rios e entre os usos da terra. Ao contrário do encontrado para as famílias, as comunidades de Chironomidae do rio Aguapeí tiveram menores índices de riqueza.

Em relação às famílias, há maior diversidade nas comunidades provenientes da pastagem e estas possuem melhor distribuição do número de indivíduos em cada táxon, vide os índices de uniformidade e EPT.

Ao observar os mesmos índices calculados para os gêneros, a mesma tendência (das famílias) é encontrada, porém sua evidência é mais discreta.

Grande é a presença de táxons endêmicos e analisando-se a comunidade em nível de família, a endemia é maior no rio Aguapeí; sendo a mata o local mais favorável. Porém, ao analisar em nível genérico, o rio São José dos Dourados apresentou maiores valores de táxons exclusivos, cuja proporção nas comunidades foi semelhante nos dois usos da terra.

Além disso, três táxons (Culicidae, Odontoceridae e um morfotipo de Odonata) foram encontrados exclusivamente nas amostras dos trechos contendo a cobertura de mata ripária, enquanto que as famílias exclusivas à pastagem foram Hydraenidae, Noteridae, Psephenidae e Ptilodactilydae (todas pertencentes aos Coleoptera) e mais Leptoceridae.

Esta distribuição errática dos táxons, sendo ausentes ou raros em um ambiente e muito abundantes em outro foi observada por Melo \& Froehlich (2001), em córregos de um Parque do Estado de São Paulo. Segundo os autores, a estocasticidade pode ocorrer numa escala temporal; com espécies ausentes ou raras tornando-se altamente abundantes após alguns anos.

Nessimian (1997) analisou hábitos alimentares de macroinvertebrados amostrados em brejos do Estado do Rio de Janeiro e verificou que grande parte das espécies coletadas possui hábito generalista e oportunista, alimentando-se do que estiver 
disponível no momento. Ainda, Pinder (1986) identificou outros hábitos alimentares além de predador para diversos gêneros de Tanypodinae, família reconhecida pelo hábito predatório.

Em estudo conduzido em microbacias com dois tipos de ocupação do solo, i.e. florestadas e cultivadas, Arcova \& Cicco (1999), puderam confirmar a constatação da diferença de temperatura da água em locais sombreados daqueles expostos à radiação solar, evidenciando maior valor para estes últimos.

A maior incidência solar influencia na produtividade de algas, principalmente. Estas, por obterem este recurso energético mais facilmente, aumentam sua capacidade fotossintética, conseqüentemente aumentam em biomassa. Os macroinvertebrados, por sua vez, tiram proveito da abundância de algas já que as utilizam como fonte de alimento.

Por outro lado, a diminuição da cobertura vegetal pela mata ciliar, leva à menor disponibilização de matéria orgânica, na forma de folhas, galhos, sementes, que é utilizada como alimento e substrato para nidificação (Naiman \& Décamps, 1997).

Apesar da elevada participação de Chironomidae nas comunidades evidenciada nos trabalhos ecológicos com insetos aquáticos (Balci \& Kennedy, 2000; GuereschiAguirre \& Fonseca-Gessner, 1999), a dominância numérica da família neste estudo também pode ser explicada pelo fato de suas larvas serem normalmente encontradas nas regiões menos profundas de ambientes aquáticos (Callisto et al., 2002).

No presente estudo, Rheotanytarsus spp. e Ablabesmyia spp. foram os táxons mais abundantes dentre os gêneros de Chironomidae em ambos os usos do solo. Esta elevada participação de Rheotanytarsus spp. em comunidades amostradas com substrato artificial em córregos também foi evidenciada por Figueiredo et al. (2001). Corbi \& Trivinho-Strixino (1999) analisaram a macrofauna bentônica de rios sob influência da plantação de cana-de-açúcar no interior do Estado de São Paulo. Dentre seus resultados, os autores encontraram predomínio de Rheotanytarsus spp. e Ablabesmyia spp. em locais de melhor qualidade da água. 


\section{CONCLUSÕES}

O estudo em escala regional foi importante ao fornecer informações a respeito da entomofauna aquática de alguns rios de grande porte do estado de São Paulo, com relação a sua diversidade e riqueza faunística.

A influência do uso da terra nas comunidades de insetos aquáticos aparentemente está muito mais relacionada com o entorno imediato ao local no qual vivem (zona ripária) que à região como um todo.

Poucas variáveis químicas e físicas da água foram significativas para representar os rios. As variáveis que apresentaram relação com as famílias mais abundantes (ou índices comunitários) foram $\mathrm{pH}$, condutividade, temperatura, carbono inorgânico dissolvido (DIC), íon cloreto, $\mathrm{NO}_{2}, \mathrm{NO}_{3}, \mathrm{SO}_{4}$, sódio, potássio, magnésio e cálcio.

Praticamente todos os tipos de uso e cobertura do solo apresentaram relação linear com uma das famílias mais abundantes (ou índices comunitários); o mesmo foi observado para os intervalos de declividade do terreno.

Para os gêneros mais abundantes (ou os índices comunitários), um número menor de variáveis químicas e físicas apresentou relação linear com os mesmos [temperatura, cálcio, sódio, $\mathrm{SO}_{4}$ e total de sólidos suspensos na água (TSS)]. Da mesma forma, apenas seis tipos de uso do solo apresentaram relação linear quando analisados em função deste nível taxonômico. Em relação à declividade, apenas o intervalo considerado acima de 70\% apresentou relação positiva com Beardius spp.

A utilização do nível de gênero para este tipo de estudo foi mais conclusiva que o nível de família.

Quanto ao estudo em escala local, foi possível verificar a importância da manutenção da integridade de toda a mata ripária ao longo dos cursos d'água, e não somente alguns trechos. 
A utilização do nível genérico para inferências ambientais mostrou ser mais precisa, neste caso, apesar de obter resultados bastante próximos ao considerar ambos níveis taxonômicos.

As métricas utilizadas para analisar os usos da terra tiveram maiores valores para as comunidades de Chironomidae provenientes de locais com mata ripária que apresentavam conformidade com a legislação ambiental vigente, ou seja, largura mínima de $50 \mathrm{~m}$ em cada margem do rio.

\subsection{Considerações Finais}

\subsubsection{Estudo em Escala Regional}

Para melhor analisar a influência dos usos e coberturas do solo em escala regional sobre as comunidades de insetos aquáticos, é necessário:

1. A realização de estudos que considerem a escala temporal, de preferência com coletas mensais;

2. Identificar os indivíduos em nível taxonômico mais apurado, ou seja, gênero ou espécie (preferivelmente);

3. Analisar as categorias alimentares dos gêneros ou espécies presentes e as possíveis relações com os usos da terra;

4. Realizar estudos em microbacias que apresentem apenas um tipo de uso da terra, possibilitando melhor análise dos resultados com diminuição das variáveis envolvidas.

\subsubsection{Estudo em Escala Local}

Apesar desta parte do estudo ter sido mais conclusivas, algumas melhorias poderiam ser feitas para a obtenção de resultados mais abrangentes:

1. A realização de estudos que considerem a escala temporal, de preferência com coletas mensais; 
2. Realizar estudos em microbacias que apresentem apenas um tipo de uso da terra, possibilitando melhor análise dos resultados com diminuição das variáveis envolvidas.

Pelas conclusões obtidas, finaliza-se enfatizando a importância dos resultados aqui encontrados e a necessidade da continuidade desta linha de pesquisa para o entendimento de rios desta magnitude e geração de informações que possam auxiliar na tomada de decisões no gerenciamento das bacias hidrográficas do Estado de São Paulo. 
A NEX O S 
Anexo A - Valores da correlação de Pearson (r) e do nível de significância (p) de cada variável que apresentou relação linear com os táxons mais abundantes numericamente e os índices comunitários de cada nível taxonômico (considerouse nível de significância $\alpha<0,07)$.

\section{Famílias}

\begin{tabular}{|c|c|c|c|c|}
\hline Elmidae & Leptohyphidae & Leptophlebiidae & Hydropsychidae & Chironomidae \\
\hline DIC & $\mathrm{CL}$ & $\mathrm{CL}$ & $\mathrm{SO} 4$ & BFURB \\
\hline$r=0,848 ; p=0,033^{*}$ & $\mathrm{r}=0,952 ; \mathrm{p}=0,003 * *$ & $\mathrm{r}=0,890 ; \mathrm{p}=0,018^{*}$ & $\mathrm{r}=0,923 ; \mathrm{p}=0,009 * *$ & $\mathrm{r}=0,810 ; \mathrm{p}=0,051 *$ \\
\hline $\mathrm{CA}$ & NA & NO3 & & \\
\hline $\mathrm{r}=0,903 ; \mathrm{p}=0,014^{*}$ & $\mathrm{r}=0,872 ; \mathrm{p}=0,024^{*}$ & $r=0,792 ; p=0,06^{*}$ & & \\
\hline SBCPER & SBSL & SBSL & & \\
\hline $\mathrm{r}=0,939 ; \mathrm{p}=0,005^{* *}$ & $\mathrm{r}=0,903 ; \mathrm{p}=0,014^{*}$ & $\mathrm{r}=0,809 ; \mathrm{p}=0,051^{*}$ & & \\
\hline SBCN & BFSL & BFVEG & & \\
\hline$r=0,873 ; p=0,023^{*}$ & $\mathrm{r}=0,874 ; \mathrm{p}=0,023^{*}$ & $\mathrm{r}=-0,780 ; \mathrm{p}=0,067^{*}$ & & \\
\hline BFCPER & SBI2_5PCT & SBI2_5PCT & & \\
\hline $\mathrm{r}=0,921 ; \mathrm{p}=0,009 * *$ & $\mathrm{r}=0,934 ; \mathrm{p}=0,006 * *$ & $\mathrm{r}=0,939 ; \mathrm{p}=0,006^{* *}$ & & \\
\hline $\mathrm{BFCN}$ & SBI10_15PCT & SBI5_10PCT & & \\
\hline \multirow[t]{5}{*}{$r=0,875 ; p=0,022 *$} & $\mathrm{r}=0,826 ; \mathrm{p}=0,043^{*}$ & $r=0,792 ; p=0,06^{*}$ & & \\
\hline & SBI15_45PCT & SBI10_15PCT & & \\
\hline & $r=-0,783 ; p=0,066^{*}$ & $\mathrm{r}=-0,822 ; \mathrm{p}=0,045^{*}$ & & \\
\hline & BFIM2PCT & SBI15_45PCT & & \\
\hline & $\mathrm{r}=0,851 ; \mathrm{p}=0,032^{*}$ & $\mathrm{r}=-0,815 ; \mathrm{p}=0,048^{*}$ & & \\
\hline
\end{tabular}




\section{Famílias}

\begin{tabular}{ll}
\hline Leptohyphidae & Leptophlebiidae \\
\hline BFI2_5PCT & BFIM2PCT \\
r=0,966; p=0,002** & $r=0,781 ; p=0,067^{*}$ \\
BFI5_10PCT & BFI2_5PCT \\
r=0,892; p=0,017* & $r=0,915 ; p=0,011^{*}$ \\
BFI15_45PCT & BFI5_10PCT \\
$r=-0,860 ; p=0,028^{*}$ & $r=0,868 ; p=0,025^{*}$ \\
& BFI15_45PCT \\
& $r=-0,844 ; p=0,035^{*}$
\end{tabular}

Simuliidae apesar de também serem numericamente dominantes, não apresentaram correlação com qualquer uma das variáveis analisadas. $*<0,07 ; * *<0,01 ; * * *<0,001$.

\section{Índices comunitários das famílias}

\begin{tabular}{lll}
\hline Diversidade & Riqueza & Uniformidade \\
\hline TEMP & TEMP & TEMP \\
$r=0,964 ; \mathrm{p}=0,002^{* *}$ & $\mathrm{r}=0,825 ; \mathrm{p}=0,043^{*}$ & $\mathrm{r}=0,956 ; \mathrm{p}=0,003^{* *}$ \\
CO2 & $\mathrm{CO} 2$ & COND \\
$\mathrm{r}=0,944 ; \mathrm{p}=0,005^{* *}$ & $\mathrm{r}=0,799 ; \mathrm{p}=0,057^{*}$ & $\mathrm{r}=0,81 ; \mathrm{p}=0,051^{*}$ \\
NO3 & $\mathrm{K}$ & $\mathrm{CO} 2$ \\
$\mathrm{r}=0,916 ; \mathrm{p}=0,01^{* *}$ & $\mathrm{r}=0,808 ; \mathrm{p}=0,052^{*}$ & $\mathrm{r}=0,935 ; \mathrm{p}=0,006^{* *}$
\end{tabular}


Índices comunitários das famílias

\begin{tabular}{|c|c|c|}
\hline Diversidade & Riqueza & Uniformidade \\
\hline $\mathrm{K}$ & SBPT & NO3 \\
\hline $\mathrm{r}=0,969 ; \mathrm{p}=0,001^{* *}$ & $r=0,937 ; p=0,006^{* *}$ & $r=0,907 ; p=0,013^{*}$ \\
\hline SBPT & SBVEG & $\mathrm{K}$ \\
\hline $\mathrm{r}=0,971 ; \mathrm{p}=0,001^{* *}$ & $r=-0,889 ; p=0,018^{*}$ & $\mathrm{r}=0,971 ; \mathrm{p}=0,001^{* *}$ \\
\hline SBVEG & SBREFL & SBPT \\
\hline $\mathrm{r}=-0,979 ; \mathrm{p}=0,001^{* *}$ & $r=-0,965 ; p=0,002 * *$ & $\mathrm{r}=0,933 ; \mathrm{p}=0,007^{* *}$ \\
\hline SBREFL & SBOUT & SBVEG \\
\hline $\mathrm{r}=-0,892 ; \mathrm{p}=0,017^{*}$ & $r=-0,912 ; \mathrm{p}=0,011^{*}$ & $\mathrm{r}=-0,957 ; \mathrm{p}=0,003^{* *}$ \\
\hline SBURB & BFPT & SBREFL \\
\hline $\mathrm{r}=0,811 ; \mathrm{p}=0,05^{*}$ & $r=0,917 ; p=0,01^{*}$ & $\mathrm{r}=-0,851 ; \mathrm{p}=0,032^{*}$ \\
\hline BFPT & BFVEG & SBURB \\
\hline $\mathrm{r}=0,955 ; \mathrm{p}=0,003^{* *}$ & $r=-0,906 ; p=0,013^{*}$ & $P=0,775 ; \mathrm{p}=0,07^{*}$ \\
\hline BFVEG & BFREFL & BFPT \\
\hline $\mathrm{r}=-0,973 ; \mathrm{p}=0,001^{* *}$ & $\mathrm{r}=-0,959 ; \mathrm{p}=0,002 * *$ & $r=0,913 ; p=0,011^{*}$ \\
\hline BFREFL & BFOUT & BFVEG \\
\hline$r=-0,886 ; p=0,019 *$ & $r=-0,914 ; p=0,011^{*}$ & $\mathrm{r}=-0,944 ; \mathrm{p}=0,005^{* *}$ \\
\hline SBI5_10PCT & SBI2_5PCT & BFREFL \\
\hline $\mathrm{r}=0,950 ; \mathrm{p}=0,004^{* *}$ & $\mathrm{r}=0,813 ; \mathrm{p}=0,049 *$ & $\mathrm{r}=-0,837 ; \mathrm{p}=0,038^{*}$ \\
\hline
\end{tabular}


Índices comunitários das famílias

\begin{tabular}{|c|c|c|}
\hline Diversidade & Riqueza & Uniformidade \\
\hline SBI15_45PCT & SBI5_10PCT & SBIM2PCT \\
\hline $\mathrm{P}=-0,930 ; \mathrm{p}=0,007^{* *}$ & $\mathrm{r}=0,883 ; \mathrm{p}=0,02^{*}$ & $r=0,78 ; p=0,067^{*}$ \\
\hline BFIM2PCT & SBI15_45PCT & SBI2_5PCT \\
\hline $\mathrm{r}=0,880 ; \mathrm{p}=0,021^{*}$ & $r=-0,864 ; p=0,026^{*}$ & $r=0,793 ; p=0,06^{*}$ \\
\hline BFI2_5PCT & BFI5_10PCT & SBI5_10PCT \\
\hline $\mathrm{r}=0,779 ; \mathrm{p}=0,068^{*}$ & $\mathrm{r}=0,837 ; \mathrm{p}=0,038^{*}$ & $\mathrm{r}=0,913 ; \mathrm{p}=0,011^{*}$ \\
\hline BFI5_10PCT & BFI15_45PCT & SBI15_45PCT \\
\hline$r=0,899 ; p=0,015^{*}$ & $r=-0,835 ; p=0,039 *$ & $r=-0,89 ; p=0,018^{*}$ \\
\hline BFI15_45PCT & & BFIM2PCT \\
\hline \multirow[t]{5}{*}{$r=-0,924 ; p=0,008^{* *}$} & & $\mathrm{r}=0,857 ; \mathrm{p}=0,029 *$ \\
\hline & & BFI5_10PCT \\
\hline & & $\mathrm{r}=0,861 ; \mathrm{p}=0,028^{*}$ \\
\hline & & BFI15_45PCT \\
\hline & & $r=-0,895 ; p=0,016^{*}$ \\
\hline
\end{tabular}




\section{Gêneros}

\begin{tabular}{|c|c|c|c|c|}
\hline Corynoneura spp. & Nanocladius spp. & Beardius spp. & Polypedilum (Pol.) spp. & Ablabesmyia spp. \\
\hline TEMP & TEMP & SBCPER & CA & NA \\
\hline$r=0,836 ; p=0,038 *$ & $\mathrm{r}=0,84 ; \mathrm{p}=0,037^{*}$ & $\mathrm{r}=0,775 ; \mathrm{p}=0,07^{*}$ & $\mathrm{r}=0,817 ; \mathrm{p}=0,047^{*}$ & $r=0,799 ; p=0,057^{*}$ \\
\hline SBCPER & SBPT & BFCPER & SBCPER & \\
\hline$r=0,864 ; p=0,026^{*}$ & $r=0,893 ; p=0,016^{*}$ & $\mathrm{r}=0,841 ; \mathrm{p}=0,036^{*}$ & $r=0,868 ; p=0,025^{*}$ & \\
\hline SBCN & SBVEG & SBIMA70PCT & BFCPER & \\
\hline$r=0,885 ; p=0,019 *$ & $r=-0,821 ; p=0,045^{*}$ & $\mathrm{r}=0,883 ; \mathrm{p}=0,02^{*}$ & $r=0,908 ; p=0,012^{*}$ & \\
\hline SBREFL & SBREFL & BFIMA70PCT & BFCN & \\
\hline$r=-0,791 ; p=0,061^{*}$ & $r=-0,904 ; p=0,013^{*}$ & $\mathrm{r}=0,847 ; \mathrm{p}=0,033^{*}$ & $\mathrm{r}=0,838 ; \mathrm{p}=0,039 *$ & \\
\hline BFCPER & BFPT & & & \\
\hline$r=0,845 ; p=0,034^{*}$ & $\mathrm{r}=0,925 ; \mathrm{p}=0,008^{* *}$ & & & \\
\hline BFVEG & BFVEG & & & \\
\hline$r=-0,806 ; p=0,053^{*}$ & $r=-0,898 ; p=0,015^{*}$ & & & \\
\hline BFCN & BFREFL & & & \\
\hline $\mathrm{r}=0,852 ; \mathrm{p}=0,031^{*}$ & $r=-0,945 ; p=0,004^{* *}$ & & & \\
\hline BFREFL & BFOUT & & & \\
\hline \multirow[t]{5}{*}{$r=-0,832 ; p=0,04^{*}$} & $\mathrm{r}=-0,905 ; \mathrm{p}=0,013^{*}$ & & & \\
\hline & SBIM2PCT & & & \\
\hline & $\mathrm{r}=0,819 ; \mathrm{p}=0,046^{*}$ & & & \\
\hline & SBI5_10PCT & & & \\
\hline & $r=0,895 ; p=0,016^{*}$ & & & \\
\hline
\end{tabular}




\section{Gêneros}

$$
\begin{aligned}
& \hline \text { Nanocladius spp. } \\
& \hline \text { SBI15_45PCT } \\
& \mathrm{r}=-0,878 ; \mathrm{p}=0,021^{*} \\
& \text { SBOUT } \\
& \mathrm{r}=-0,927 ; \mathrm{p}=0,008^{* *} \\
& *<0,07 ; * *<0,01 ; * * *<0,001 .
\end{aligned}
$$

* Rheotanytarsus spp., Labrundinia spp. e Lopescladius spp. apesar de serem gêneros numericamente dominantes, não apresentaram correlação com qualquer uma das variáveis analisadas. * <0,07; **<0,01; ***<0,001.

\section{Índices comunitários dos gêneros}

\begin{tabular}{lll}
\hline Diversidade & Riqueza & Uniformidade \\
\hline SBCPER & FSS & SBCPER \\
$r=0,863 ; \mathrm{p}=0,027^{*}$ & $\mathrm{r}=-0,852 ; \mathrm{p}=0,031^{*}$ & $\mathrm{r}=0,873 ; \mathrm{p}=0,023^{*}$ \\
SBCN & SO4 & SBCN \\
$\mathrm{r}=0,900 ; \mathrm{p}=0,014^{*}$ & $\mathrm{r}=-0,884 ; \mathrm{p}=0,019^{*}$ & $\mathrm{r}=0,907 ; \mathrm{p}=0,013^{*}$ \\
BFCPER & & BFCPER \\
$\mathrm{r}=0,890 ; \mathrm{p}=0,018^{*}$ & & $\mathrm{r}=0,896 ; \mathrm{p}=0,016^{*}$ \\
BFCN & & $\mathrm{BFCN}$ \\
$\mathrm{r}=0,928 ; \mathrm{p}=0,008^{* *}$ & & $\mathrm{r}=0,935 ; \mathrm{p}=0,006^{* *}$ \\
\hline
\end{tabular}


Anexo B - Resultados da ANOVA demonstrando os valores significativos para as variáveis físicas e químicas da água que diferenciaram entre os rios (nível de significância $\alpha<0,05)$.

COND (condutividade) $\mathrm{F}=43,12 ; \mathrm{p}<0,0001$

\begin{tabular}{cccc}
\hline \multicolumn{2}{c}{ Agrupamento do Tukey } & Média & rio \\
\hline & A & 159,2 & Peixe \\
B & A & 145,9 & São José dos Dourados \\
B & C & 115,1 & Aguapeí \\
D & C & 109,0 & Taquari \\
D & & 78,8 & Apiaí-Guaçu \\
& E & 29,3 & Paranapanema \\
\hline
\end{tabular}

DIC (carbono inorgânico dissolvido) F=49,11; $p<0,0001$

\begin{tabular}{cccc}
\hline \multicolumn{2}{c}{ Agrupamento do Tukey } & Média & rio \\
\hline & A & 69,5 & Peixe \\
& B & 48,1 & São José dos Dourados \\
C & B & 45,2 & Aguapeí \\
C & B & 39,2 & Taquari \\
C & & 31,8 & Apiá-Guaçu \\
& D & 6,3 & Paranapanema \\
\hline
\end{tabular}

CL (íon cloreto) F=36,75; $\mathrm{p}<0,0001$

\begin{tabular}{ccc}
\hline Agrupamento do Tukey & Média & rio \\
\hline A & 261,0 & São José dos Dourados \\
B & 108,4 & Aguapeí \\
B & 102,7 & Paranapanema \\
B & 70,2 & Peixe \\
B & 62,3 & Apiaí-Guaçu \\
B & 59,6 & Taquari \\
\hline
\end{tabular}


$\mathbf{N O}_{2} \mathrm{~F}=67,24 ; \mathrm{p}<0,0001$

\begin{tabular}{ccc}
\hline Agrupamento do Tukey & Média & rio \\
\hline A & 35,7 & Peixe \\
B & 27,9 & Aguapeí \\
B & 25,8 & São José dos Dourados \\
B & 24,4 & Taquari \\
B & 22,8 & Apiaí-Guaçu \\
C & 0,0 & Paranapanema \\
\hline
\end{tabular}

$\mathbf{N O}_{3} \mathrm{~F}=7,19 ; p=0,0025$

\begin{tabular}{|c|c|c|c|}
\hline \multicolumn{2}{|c|}{ Agrupamento do Tukey } & Média & rio \\
\hline & $\mathrm{A}$ & 98,5 & São José dos Dourados \\
\hline B & A & 76,1 & Aguapeí \\
\hline B & A C & 55,9 & Peixe \\
\hline B & $\mathrm{C}$ & 35,1 & Taquari \\
\hline B & $\mathrm{C}$ & 29,8 & Paranapanema \\
\hline & $\mathrm{C}$ & 16,4 & Apiaí-Guaçu \\
\hline
\end{tabular}

$\mathbf{S O}_{4} \mathrm{~F}=19,80 ; \mathrm{p}<0,0001$

\begin{tabular}{ccc}
\hline Agrupamento do Tukey & Média & rio \\
\hline A & 78,2 & Taquari \\
B & 44,4 & São José dos Dourados \\
C & 13,4 & Peixe \\
C & 13,1 & Aguapeí \\
C & 12,0 & Apiaí-Guaçu \\
C & 9,3 & Paranapanema \\
\hline
\end{tabular}

NA (sódio) $F=33,75 ; \mathrm{p}<0,0001$

\begin{tabular}{cccc}
\hline \multicolumn{2}{c}{ Agrupamento do Tukey } & Média & rio \\
\hline A & 359,1 & São José dos Dourados \\
B & 221,8 & Taquari \\
C & B & 160,3 & Aguapeí \\
C & & 102,5 & Paranapanema \\
C & 98,9 & Apiaí-Guaçu \\
C & 90,3 & Peixe \\
\hline
\end{tabular}


$\mathbf{K}$ (potássio) F=38,56; $\mathrm{p}<0,0001$

\begin{tabular}{|c|c|c|c|}
\hline Agrupament & o do Tukey & Média & rio \\
\hline & A & 102,8 & São José dos Dourados \\
\hline & A & 93,8 & Aguapeí \\
\hline & B & 64,8 & Peixe \\
\hline $\mathrm{C}$ & B & 54,2 & Taquari \\
\hline $\mathrm{C}$ & $\mathrm{D}$ & 38,2 & Apiaí-Guaçu \\
\hline & $\mathrm{D}$ & 13,9 & Paranapanema \\
\hline
\end{tabular}

MG (magnésio) F=19,90; $\mathrm{p}<0,0001$

\begin{tabular}{cccc}
\hline \multicolumn{2}{l}{ Agrupamento do Tukey } & Média & rio \\
\hline & A & 196,4 & Peixe \\
B & A & 161,0 & São José dos Dourados \\
B & A & 153,4 & Taquari \\
B & & 134,7 & Aguapeí \\
B & & 125,4 & Apiá-Guaçu \\
& C & 34,2 & Paranapanema \\
\hline
\end{tabular}

CA (cálcio) F=90,69; p <0,0001

\begin{tabular}{|c|c|c|}
\hline Agrupamento do Tukey & Média & rio \\
\hline A & 566,7 & Peixe \\
\hline B & 337,8 & São José dos Dourados \\
\hline B & 337,7 & Aguapeí \\
\hline C B & 257,0 & Taquari \\
\hline C & 195,1 & Apiaí-Guaçu \\
\hline $\mathrm{D}$ & 32,8 & Paranapanema \\
\hline
\end{tabular}


Anexo C - Percentuais dos usos da terra nas sub-bacias de cada rio

\begin{tabular}{lcccccc}
\hline Usos da terra & Paranapanema & $\begin{array}{c}\text { Apiaí- } \\
\text { Guaçu }\end{array}$ & Taquari & Peixe & Aguapeí & $\begin{array}{c}\text { S. J. } \\
\text { Dourados }\end{array}$ \\
\hline Pastagem & 22,6 & 39,0 & 25,3 & 47,8 & 70,9 & 75,5 \\
Culturas perenes & 2,3 & 3,6 & 3,3 & 10,2 & 5,7 & 5,6 \\
Veget. nat. perman. & 56,7 & 43,7 & 47,2 & 35,3 & 16,1 & 10,0 \\
Cana-de-açúcar & 0,1 & 0,4 & 0,3 & 5,0 & 2,2 & 3,1 \\
Reflorestamento & 16,2 & 6,2 & 17,9 & 0,6 & 0,4 & 0,03 \\
Corpos d'água & 0,04 & 0,4 & 0,2 & 0,01 & 0,02 & 0,04 \\
Cultura temporária & 0,6 & 4,4 & 3,1 & 0,03 & 2,5 & 0,3 \\
Solo exposto & 1,3 & 2,3 & 2,3 & 1,1 & 1,3 & 4,8 \\
Área urbana & 0,0 & 0,0 & 0,0 & 0,0 & 0,9 & 0,7 \\
Outros & 0,2 & 0,1 & 0,4 & 0,01 & 0,001 & 0,003 \\
\hline
\end{tabular}

Anexo D - Participação relativa de cada uso da terra na zona tampão das sub-bacias

Apiaí-

S. J.

Usos da terra Paranapanema Guaçu Taquari Peixe Aguapeí Dourados

\begin{tabular}{lcccccc}
\hline Pastagem & 23,0 & 28,9 & 19,6 & 48,1 & 67,3 & 74,2 \\
Culturas perenes & 41,9 & 2,1 & 2,2 & 11,3 & 4,9 & 4,6 \\
Veget. nat. perman. & 63,0 & 56,7 & 60,7 & 34,0 & 21,5 & 14,0 \\
Cana-de-açúcar & 0,2 & 0,3 & 0,2 & 5,6 & 1,9 & 2,7 \\
Reflorestamento & 10,1 & 5,5 & 12,7 & 0,4 & 0,4 & 0,01 \\
Corpos d'água & 0,02 & 0,5 & 0,2 & 0,0 & 0,1 & 0,1 \\
Cultura temporária & 0,4 & 3,8 & 2,3 & 0,03 & 2,9 & 0,3 \\
Solo exposto & 1,2 & 2,1 & 1,8 & 0,5 & 1,0 & 4,0 \\
Área urbana & 0,0 & 0,0 & 0,0 & 0,0 & 0,1 & 0,1 \\
Outros & 0,2 & 0,04 & 0,3 & 0,0 & 0,002 & 0,0 \\
\hline
\end{tabular}


Anexo E - Porcentagem da área do terreno das sub-bacias ocupada por cada classe de declividade

S. J.

\begin{tabular}{lcccccc} 
Intervalo & Paranapanema & Apiaí-Guaçu & Taquari & Peixe & Aguapeí & Dourados \\
\hline$<2 \%$ & 23,2 & 21,4 & 21,1 & 23,3 & 33,6 & 35,7 \\
$2 \%$ a $5 \%$ & 4,5 & 4,1 & 3,9 & 7,6 & 11,3 & 20,2 \\
5\% a $10 \%$ & 13,4 & 14,1 & 13,0 & 22,1 & 29,0 & 32,3 \\
10\% a 15\% & 12,7 & 16,4 & 17,7 & 14,9 & 14,0 & 8,6 \\
$15 \%$ a 45\% & 40,3 & 41,0 & 41,9 & 26,3 & 11,4 & 2,6 \\
45\% a 70\% & 4,8 & 2,1 & 1,7 & 4,4 & 0,3 & 0,0001 \\
$>$ 70\% & 1,1 & 1,0 & 0,7 & 1,5 & 0,3 & 0,6 \\
\hline
\end{tabular}

Anexo F - Intervalos de declividade e percentual da área ocupada na zona tampão de cada rio

\begin{tabular}{lcccccc}
\hline Intervalo & Paranapanema & Apiaí-Guaçu & Taquari & Peixe & Aguapeí & $\begin{array}{c}\text { S. J. } \\
\text { Dourados }\end{array}$ \\
\hline$<2 \%$ & 29,9 & 33,8 & 34,8 & 33,5 & 44,8 & 49,8 \\
$2 \%$ a $5 \%$ & 3,6 & 3,4 & 3,6 & 3,8 & 6,5 & 11,0 \\
$5 \%$ a $10 \%$ & 9,9 & 11,8 & 11,4 & 13,3 & 19,7 & 25,4 \\
$10 \%$ a $15 \%$ & 10,8 & 14,0 & 14,2 & 14,1 & 13,9 & 10,1 \\
$15 \%$ a 45\% & 40,0 & 35,1 & 34,4 & 29,7 & 14,6 & 3,7 \\
$45 \%$ a $70 \%$ & 5,4 & 1,6 & 1,3 & 4,9 & 0,4 & 0,0 \\
$>$ 70\% & 0,5 & 0,3 & 0,2 & 0,7 & 0,1 & 0,004 \\
\hline
\end{tabular}


Anexo G - Mapa da análise de correspondência das variáveis físicas e químicas que apresentaram relação linear com os rios

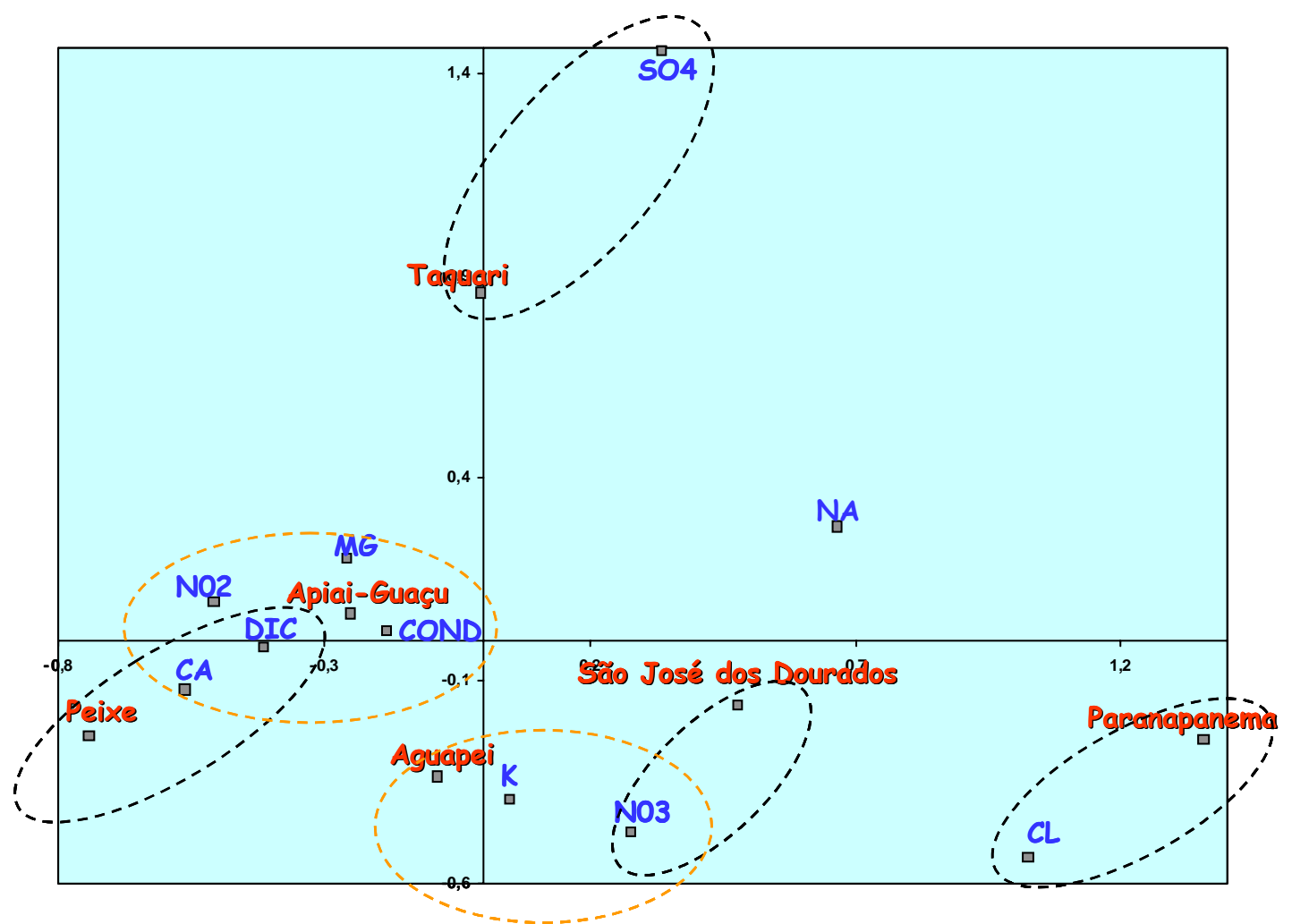

$\%$ de explicação dimensão $1=68 \%$ $\%$ de explicação dimensão $2=23 \%$ 
Anexo H - Análise de correspondência dos usos do solo na sub-bacia a montante dos locais de coleta com os rios

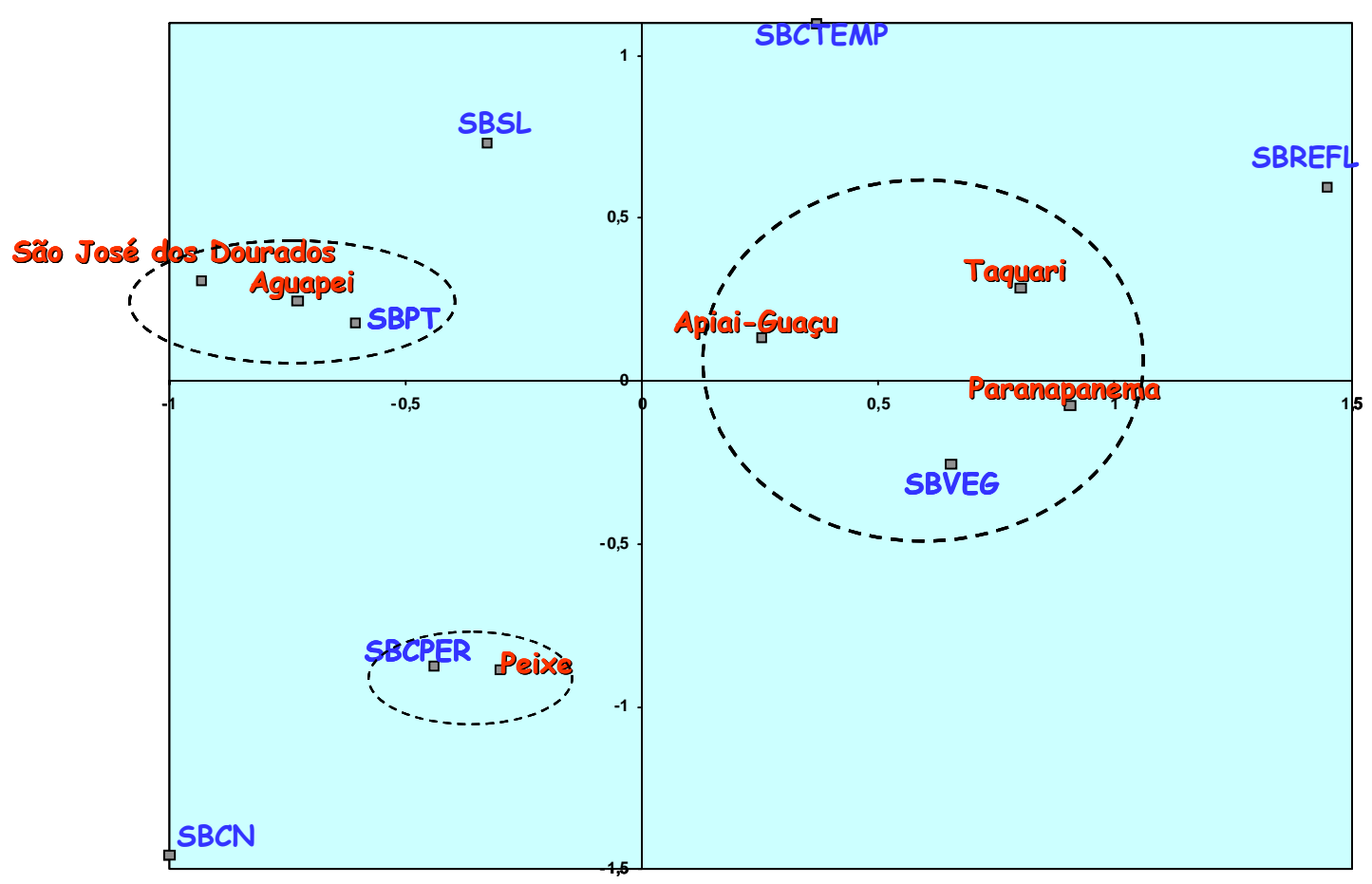

$\%$ de explicação dimensão $1=83 \%$ $\%$ de explicação dimensão $2=10 \%$ 
Anexo I - Análise de correspondência dos usos do solo da zona tampão com cada rio

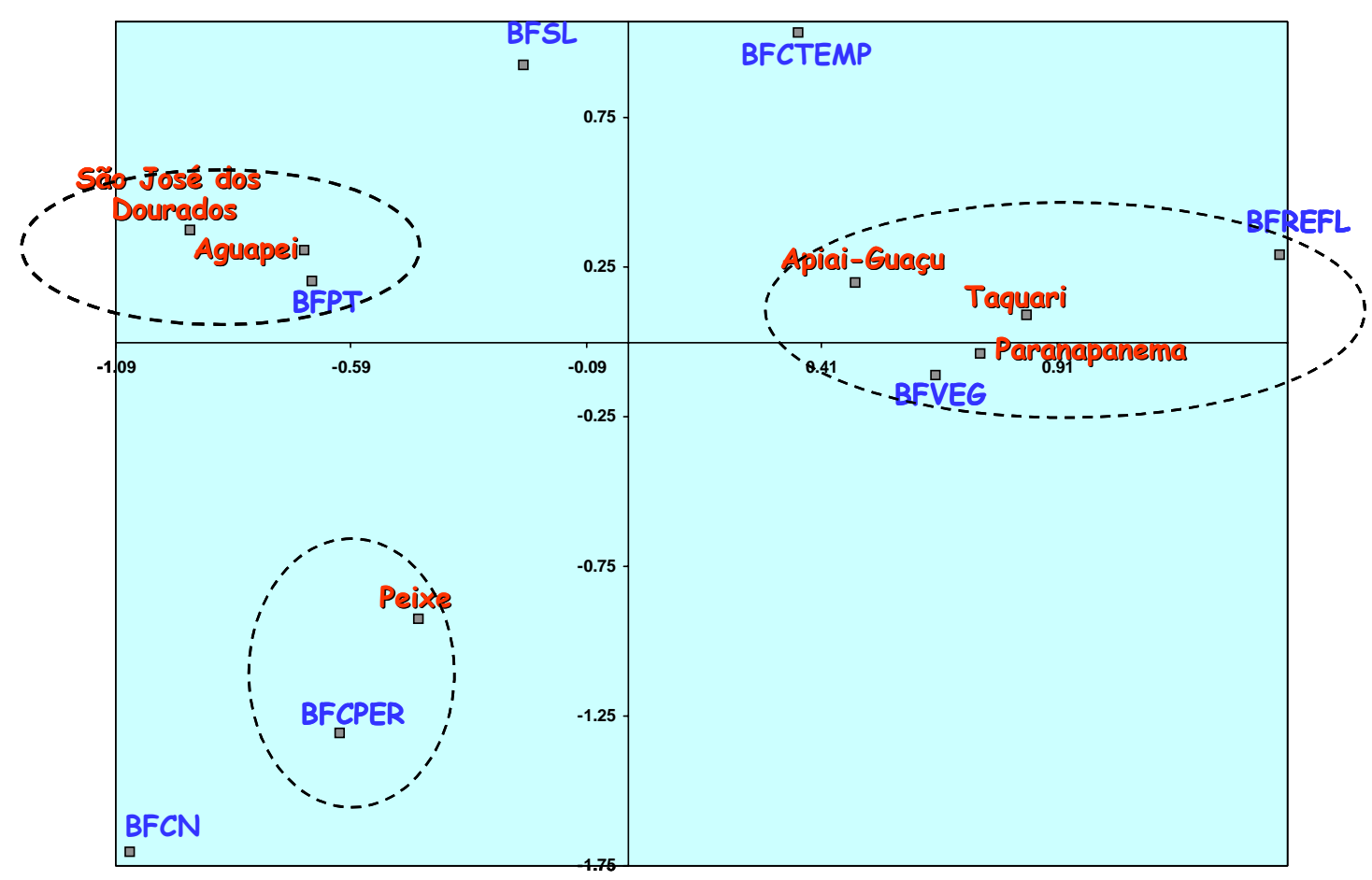

$\%$ de explicação dimensão $1=83 \%$

$\%$ de explicação dimensão $2=12 \%$ 
Anexo J - Mapa da análise de correspondência dos intervalos de declividade das subbacias e os rios estudados

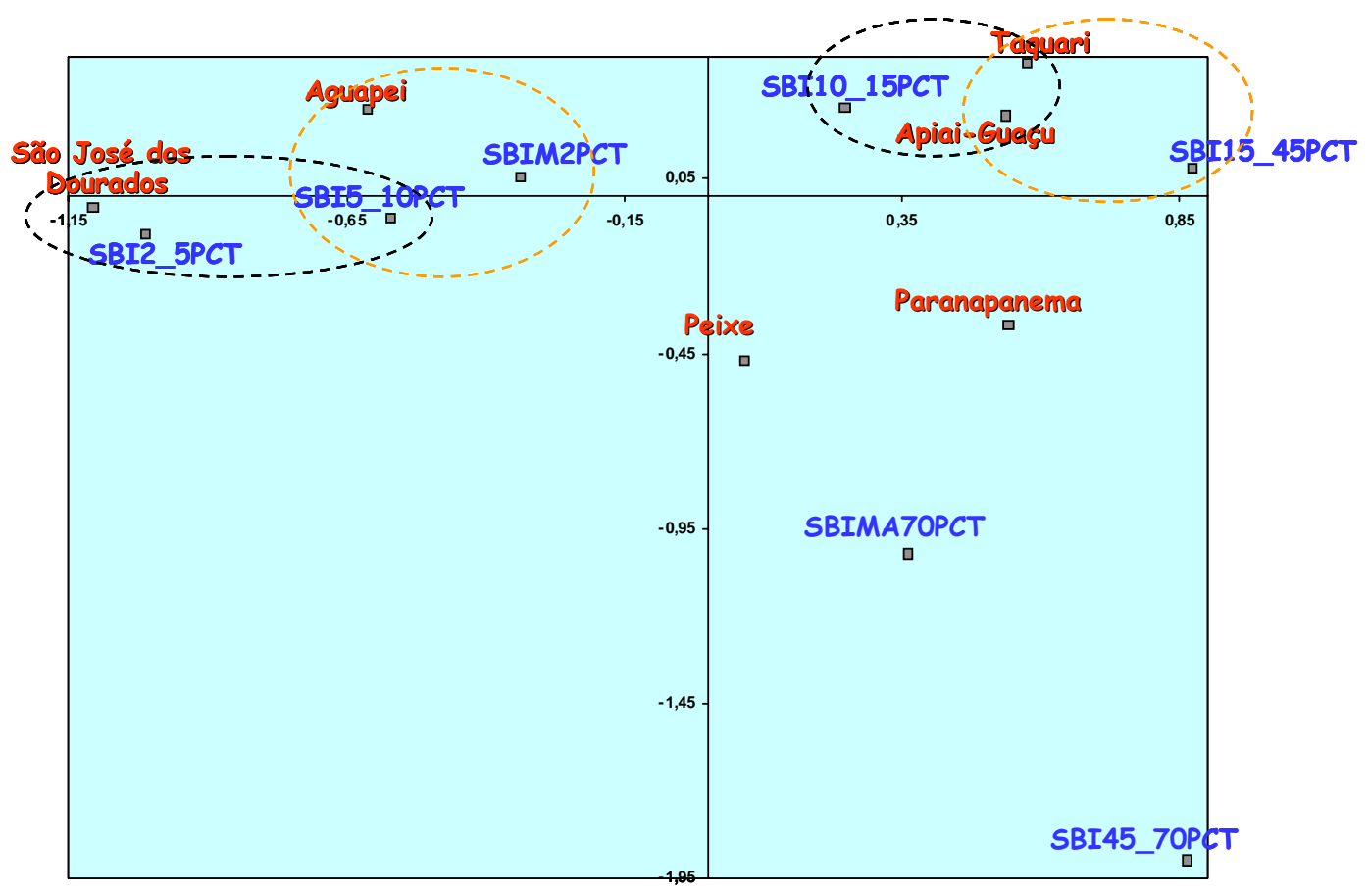

$\%$ de explicação dimensão $1=91 \%$

$\%$ de explicação dimensão $2=5 \%$ 
Anexo L - Análise de correspondência entre os intervalos de declividade da zona tampão e os rios

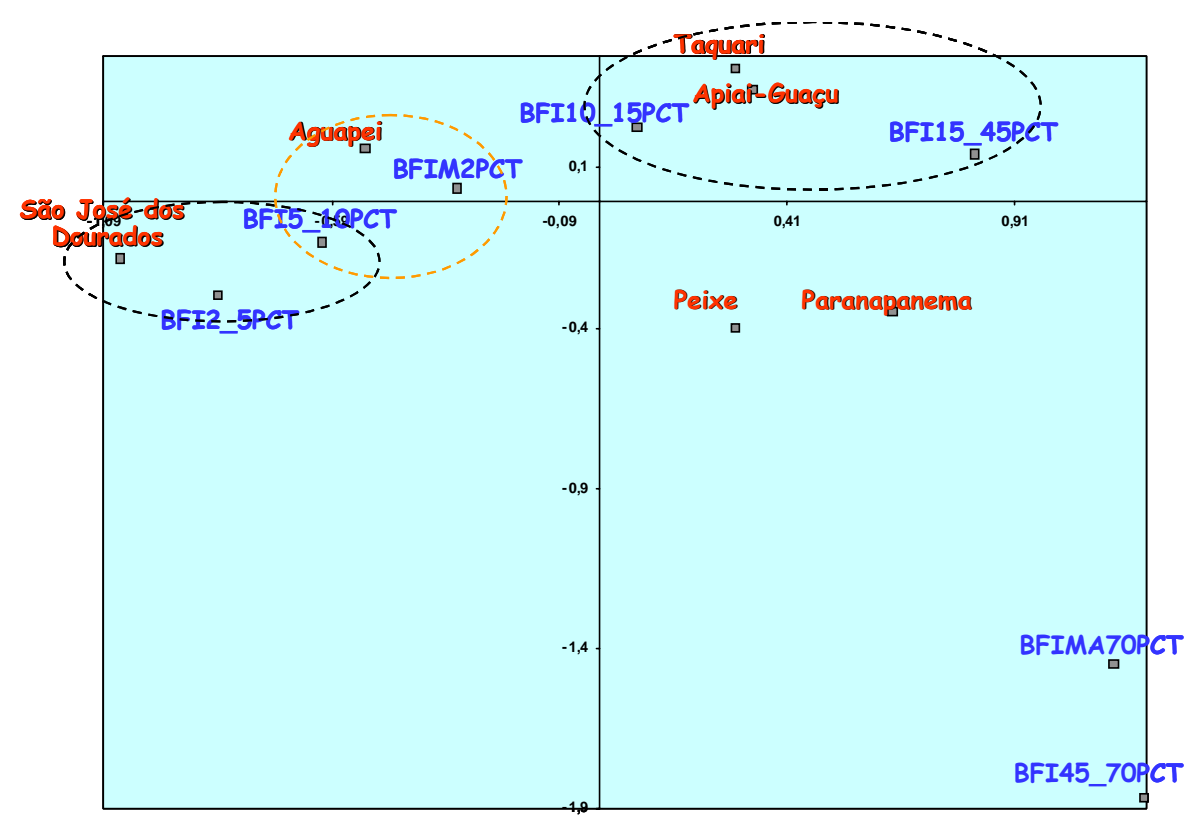

$\%$ de explicação dimensão $1=90 \%$

$\%$ de explicação dimensão $2=8 \%$ 


\section{REFERÊNCIAS BIBLIOGRÁFICAS}

AAGARD, K.; SOLEM, J. O.; BONGARD, T.; HANSSEN, O. Studies of aquatic insects in the Atna River 1987-2002. Hydrobiologia, v.521, p.87-105. 2004.

ADAMUS, P. R.; BRANDT, K. Impacts on Quality of Inland Wetlands of the United States: a Survey of Indicators, Techniques, and Applications of Communitylevel Biomonitoring Data. EPA/600/3-90/073. U.S Environmental Protection Agency. Washington, DC, EUA. 1990. 406 p.

AGUIAR, F. C.; FERREIRA, M. T.; PINTO, P. Relative influence of environmental variables on macroinvertebrate assemblages from an Iberian basin. Journal of the North American Benthological Society, v.21, n.1, p.43-53. 2002.

ALI, A. Nuisance chironomids and their control: a review. Esa Bulletin, v.26, n.1, p.316. 1980.

ANAYA, M. Impacto de um represamento sobre a comunidade de invertebrados bentônicos do Rio Mogi-Guaçu e de seu tributário, Rio do Peixe (SP, Brasil). Dissertação (Mestrado). Instituto de Ciências Biológicas, Universidade de São Paulo - USP. São Paulo, SP. 140p. 1997.

ARCOVA, F. C. S.; CICCO, V. Qualidade da água de microbacias com diferentes usos do solo na região de Cunha, Estado de São Paulo. Scientia Forestalis, v.56, p.125134. 1999. 
ARMITAGE, P. D.; PETTS, G. E. Biotic score and prediction to assess the effects of water abstractions on river macroinvertebrates for conservation purposes. Aquatic Conservation of Marine and Freshwater Ecosystems, v.2, p.1-17. 1992.

ARMITAGE, P. D.; CRANSTON, P. S.; PINDER, L. C. V. (Eds.) The Chironomidae, biology and ecology of non-biting midges. Ed. Chapamn \& Hall, NY, EUA. 1995. 800p.

BALCI, P.; KENNEDY, J. H. A comparison of the chironomid (Insecta: Diptera) and other epiphytic macroinvertebrates under selected exotic and native aquatic plant communities. XIV INTERNATIONAL SYMPOSIUM ON CHIRONOMIDAE. Proceedings, FIOCRUZ, RJ. 2000. s.p.

BARNES, R. D. Zoologia dos invertebrados. 4e. Ed. Roca, SP. 1984. 1179p.

BARROS, A. B. Organismos de bacias hidrográficas - problemas e soluções. Pp. 37-41. In: MONTICELI, J. J. (Coord.). In: WORKSHOP SOBRE ORGANISMOS DE BACIAS HIDROGRÁfICAS, 16., Semads, RJ. 2002. Papers. Rio de Janeiro:5. ed., 2002. p. 37-41.

BATIUK, R.A.; ORTH, R.J.; MOORE, K.A.; DENNISON, W.C.; STEVENSON, J. C.; STAVER, L.W.; CARTER, V.; RYBICKI, N.B.; HICKMAN, R.E.; KOLLAR, S. BIEBER, S.; HEASLY, P. Chesapeake Bay Submerged Aquatic Vegetation Habitat Requirements and Restoration Targets: a technical synthesis. EPA: Annapolis, MD. EUA 1992. s. p.

BIERREGAARD JR, R. O.; LOVEJOY, T. E.; KAPOS, V.; SANTOS, A. A.; HUTCHINGS, R. W. The biological dynamics of tropical rainforest fragments. Bioscience, v.42, n.1, p.859-866, 1992. 
BRANDIMARTE, A. L.; ANAYA, M.; SHIMIZU, G. Y. Comunidades de invertebrados bentônicos nas fases pré-e-pós enchimento em reservatórios: um estudo de caso no reservatório de aproveitamento múltiplo do rio Mogi-Guaçu (SP). In: HENRY, R. (Ed.). Ecologia de reservatórios: estrutura, função e aspectos sociais. Botucatu, SP: FUNDBIO/FAPESP, 1999. p. 375-408.

BROWN, A. V.; AGUILA, Y.; BROWN, K. B.; FOWLER, W. P. Responses of benthic macroinvertebrates in small intermittent streams to silvicultural practices. Hydrobiologia, v.347, p.119-125, 1997.

CALlistO, M.; BARBOSA, F. A. R.; MORENO, P. The influence of Eucalyptus plantations on the macrofauna associated with Salvinia auriculata in Southeast Brazil. Brazilian Journal of Biology, v.62, n.1, p.63-68, 2002.

CAPRA, F. O ponto de mutação. São Paulo, SP: Cultrix, 1982. 447p.

CARTER, M. R. Researching the agroecosystem/environmental interface. Agriculture, Ecosystems and Environment, v.83, p.3-9, 2001.

CASCORBI, U. The influence of land use systems on substrate patterns in brooks and their benthic macroinvertebrate microdistribution. Geoderma, v.105, p.179-200, 2002.

CHASE, J. M. Are there real differences among aquatic and terrestrial food webs? Tree, v.15, n.10, p.408-412, 2000.

CHARVET, S.; STATZNER, B.; USSEGLIO, P. P.; DUMONT, B. Traits of benthic macroinvertebrates in semi-natural French streams: An initial application to biomonitoring in Europe. Freshwater Biology, v.43, n.2, p. 277-296, 2000. 
CHENG, L.; COLLINS, J. D. Observations on behavior, emergence and reproduction of the marine midges Pontomyia (Diptera: Chironomidae). Marine Biology, v.58, p.1$5,1980$.

CHESSMAN, B. C.; WILLIAMS, S. A. Biodiversity and conservation of river macroinvertebrates on an expanding urban fringe: Western Sydney, New South Wales, Australia. Pacific conservation Biology, v.5, n.1, p.36-55, 1999.

COLLINS, R.; JENKINS, A. The impact of agricultural land use on stream chemistry in the Middle Hills of the Himalayas, Nepal. Journal of Hydrology, v. 185, p. 71-86, 1996.

COMITÊ DE BACIA HIDROGRÁFICA DO PONTAL DO PARANAPANEMA. Relatório de Situação dos Recursos Hídricos do Alto Paranapanema. www.sigrh.sp.gov.br/cgi-bin/ 1999. 318p.

COMITÊ DE BACIAS HIDROGRÁFICAS DOS RIOS DO PEIXE E AGUAPEÍ. Relatório de Situação dos Recursos Hídricos dos Rios Aguapeí e Peixe. www.sigrh.sp.gov.br/cgi-bin/ 1997. 228p.

CONVEY, P.; BLOCK, W. Antarctic Diptera: ecology, physiology and distribution. European Journal of Entomology, v.93, p.1-13, 1996.

COOPER, S. D.; DIEHL, S.; KRATZ, K.; SARNELLE, O. Implications of scale for patterns and processes in stream ecology. Australian Journal of Ecology, v.23, p.27-40, 1998. 
CORBI, J. J.; TRIVINHO-STRIXINO, S. Chironomidae (Diptera) e outros macroinvertebrados em rios sob influência de cultura canavieira (Araraquara - SP). In: ENCONTRO BRASILEIRO SOBRE TAXONOMIA E ECOLOGIA DE CHIRONOMIDAE, 3., Rio de Janeiro, 1999. Resumos. Rio de Janeiro: Instituto Oswaldo Cruz, 1999. s.p.

CRANSTON, P. S.; COOPER, P. D.; HARDWICK, R. A.; HUMPHREY, C. L.; DOSTINE, P. L. Tropical acid streams - the chironomid (Diptera) response in northern Australia. Freshwater Biology, v.37, p.473-483, 1997.

CRENSHAW, C. L.; VALETT, H. M. Effects of coarse particulate organic matter on fungal biomass and invertebrate density in the subsurface of a headwater stream. Journal of the North American Benthological Society, v.21, n.1, p. 28-42, 2002.

CUMMINS, K. W.; LAUFF, G. H. The influence of substrate particle size on the microdistribution of stream macrobenthos. Hydrobiologia, v.34, p.145-181, 1969.

DE BIBLY, V. C.; REYES-MARCHANT, P.; LAIR, N.; VALADAS, B. Impact of agricultural practices on a small headwater stream: terrestrial and aquatic characteristics and self-purifying processess. Hydrobiologia, v.421, p.129-139. 2000.

DEPARTAMENTO DE ÁGUAS E ENERGIA ELÉTRICA - DAEE. www.daee.sp.gov.br. (14 de janeiro de 2004).

DEL RÍO, M. G. T.; LASTRA, D. G. J. Restauración de rios y riberas. Madri, Es: Ed. Fundación Conde Del Valle de Salazar \& Ediciones Mundi-Prensa, 1998. 319p. 
DICKSON, K. L.; CAIRNS JR, J.; ARNOLD, J. C. An evaluation of the use of a basket type artificial substrate for sampling macroinvertebrate organisms. Transactions of the American Fisheries Society, v.100, n.3, p.553-559, 1971.

DUMANSKI, J.; PIERI, C. Land quality indicators: research plan. Agriculture, Ecosystems and Environment, v.81, p.93-102, 2000.

DUNNE, T.; LEOPOLD, L. B. Water in the Environmental Planning. San Francisco, EUA. Ed. W.H. Freeman, 1978. 818p.

EKHOLM, P.; KALLIO, K.; SALO, S.; PIETILÄINEN, O. P.; REKOLAINEN, S.; LAINE, Y.; JOUKOLA, M. Relationship between catchment characteristics and nutrient concentrations in an agricultural river system. Water Research, v.34, n.15, p.3709-3716, 2000.

ENGLAND, L. E.; ROSEMOND, A. D. Small reductions in forest cover weaken terrestrial-aquatic linkages in headwater streams. Freswater Biology, v. 49. p.721734, 2004.

EPLER, J. H. Identification manual for the water beetles of Florida (Coleoptera: Dryopidae, Dytiscidae, Elmidae, Gyrinidae, Haliplidae, Hydraenidae, Hydrophilidae, Noteridae, Psephenidae, Ptilodactilidae, Scirtidae). Florida, EUA: Department of Environmental Protection. 1996. s.p.

FAGUNDES, R. C. Modelagem dos riscos ambientais causados pela atividade humana em recursos hídricos através de análise geográfica computadorizada. São Paulo, SP. 2002. 98p. Tese (Doutorado). Instituto de Biociências, Universidade de São Paulo. 
FAGUNDES, R. C.; SHIMIZU, G. Y. Avaliação da qualidade da água do rio Sorocaba SP, através da comunidade bentônica. Revista Brasileira de Ecologia, v.1, p.63-66, 1997.

FERRAZ, E. S. B.; MARTINELLI, L. A.; VICTÓRIA, R. L. (Coord.) Coletânea do “Notícias PiraCena”: a bacia do Rio Piracicaba. Piracicaba, SP: Ed. C. N., 2001. 182p.

FIELD, C. B.; BEHRENFELD, M. J.; RANDERSON, J. T.; FALKOWSKI, P. Primary production of the terrestrial and oceanic components. Science, v.281, p.237-240, 1998.

FIGUEIREDO, F. O. G.; GUERESCHI, R. M.; FONSECA-GESSNER, A. A. Colonização de substrato artificial por larvas de Chironomidae no córrego BeijaFlor, Estação Ecológica de Jataí, Luiz Antônio, SP. In: ENCONTRO BRASILEIRO SOBRE CHIRONOMIDAE, 4., Ribeirão Preto, 2001. Resumos. Ribeirão Preto, SP: FFCLRP-USP, 2001. p.31.

FOOD AND AGRICULTURE ORGANIZATION OF THE UNITED NATIONS FAO. Land and water integration and river basin management. Land and water bulletin. Proceedings of an FAO informal workshop. Rome, It, 1995. 86p.

FONSECA-GESSNER, A. A.; GUERESCHI, R. M. Macroinvertebrados bentônicos na avaliação da qualidade da água de três córregos na Estação Ecológica de Jatai, Luiz Antônio, SP, Brasil. In: SANTOS, J. E.; PIRES, J. S. R. (Ed.) Estação Ecológica de Jataí. São Carlos, SP: RiMa Editora, 2000. p. 707-720.

FORBES, 1887. The lake as a microcosm. Peoria, IL (Bulletin of the Scientific Association), 1887. p. 77-87. 
FORE, L. S.; KARR, J. R.; WISSEMAN, R. W. Assessing invertebrate responses to human activities: evaluating alternative approaches. Journal of the North American Benthological Society, v.15, n.2, p.212-231, 1996.

FOY, R. H.; LENNOX, S. D.; SMITH, R. V. Assessing the effectiveness of regulatory controls on farm pollution using chemical and biological indices of water quality and pollution statistics. Water Research, v.35, n.12, p.3004-3012, 2001.

FRIBERG, N.; WINTERBOURN, M. J. Effects of native and exotic forest on benthic stream biota in New Zealand: a colonization study. Marine and Freshwater Research, v.48, p.267-275, 1997.

GALDEAN, N.; CALLISTO, M.; BARBOSA, F. A. R. Biodiversity assessment of benthic macroinvertebrates in altitudinal lotic ecosystems of Serra do Cipó (MG, Brazil). Revista Brasileira de Biologia, v.61, n.2, p.239-248, 2001.

GARCIA, G. J. Sensoriamento remoto. Princípios e interpretação de imagens. São Paulo, SP: Ed. Livraria Nobel, 1982. 357p.

GERHARD, P. Comunidades de peixes de riachos em função da paisagem da bacia do Rio Corumbataí, Estado de São Paulo. Piracicaba, SP, 2005. 241p. Tese (Doutorado) - Escola Superior de Agricultura “Luiz de Queiróz”, Universidade de São Paulo.

GERGEL, S. E.; TURNER, M. G.; MILLER, J. R.; MELACK, J. M.; STANLEY, E. H. Landscape indicators of human impacts to riverine systems. Aquatic Science, v.64, p.118-128, 2002.

GIUPPONI, C.; ROSATO, P. Agricultural land use changes and water quality: a case study in the watershed of the Lagoon of Venice. Water Science and Technology, v.39, n.3, p.135-148, 1999. 
GUERESCHI-AGUIRRE, R. M.; FONSECA-GESSNER, A. A. Avaliação da qualidade da água de três córregos na Estação Ecológica de Jataí, Luiz Antônio, SP (Brasil), através do uso de Chironomidae como bioindicadores. In: ENCONTRO BRASILEIRO SOBRE TAXONOMIA E ECOLOGIA DE CHIRONOMIDAE, 3., Rio de Janeiro, 1999. Resumos. Rio de Janeiro: Instituto Oswaldo Cruz, RJ. 1999. p.18.

GUEROLD, F. Influence of taxonomic determination level on several community indices. Water Research, v.34, n.2, p.487-492, 2000.

HALL, D. L.; BERGTHOLD, B. S.; SITES, R. W. The influence of adjacent land uses on macroinvertebrate communities of prairie streams in Missouri. Journal of Freshwater Ecology, v.18, n.1, p.55-68, 2003.

HANSEN, W. F. Identifying stream types and management implications. Forest Ecology and Management, v.143, p.39-46, 2001.

HANSEN, B.; ALROE, H. F.; KRISTENSEN, E. S. Review - Approaches to assess the environmental impact of organic farming with particular regard to Denmark. Agriculture, Ecosystems and Environment, v.83, p.11-26, 2001.

HEWITT, J. E.; THRUST, S. F.; CUMMINGS, V. J.; TURNER, S. J. The effects of changing sampling scales on our ability to detect effects of large-scale processes on communities. Journal of Experiments in Marine Biology and Ecology, v.227, p.251-264, 1998.

HUMPHRIES, P.; GROWNS, J. E.; SERAFINI, L. G.; KAWKING, J. H.; CHICK, A. J.; LAKE, P. S. Macroinvertebrate sampling methods for lowland Australian rivers. Hydrobiologia. V.364, p.209-218, 1998. 
HYNES, H. B. N. The ecology of running waters. Toronto, Ca: University of Toronto Press, 1972. p.?

INOUE, M.; NAKAGOSHI, N. The effects of human impact on spatial structure of the riparian vegetation along the Ashida river, Japan. Lanscape and Urban Planning, v.53, p.111-121, 2001.

JOHNSON, R. K.; PEJLER, B. Life histories and coexistence of the two profundal Chironomus species in Lake Erken, Sweden. Entomologica Scandinavia Supplement, v.29, p.139-162, 1987.

KARR, J. R. Landscapes and management for ecological integrity. In: KIM, K. C. \& WEAVER, R. D. (Ed.). Biodiversity and landscapes: a paradox of humanity. New York, EUA: Cambridge University Press,. 1994. p.229-251.

KARR, J. R. Using biological criteria to protect ecological health. In: RAPPORT, D. J.; GAUDET, C.L.; CALOW, P. (Ed.). Evaluating and monitoring the health of large-scale ecosystems. Series I: Global environmental change. Berlin: SpringerVerlag, 1995. p.137-152.

KARR, J. R. Rivers as sentinels: using the biology of rivers to guide landscape management. In: NAIMAN, R. J. \& BILBY, R. E. (Eds.). Rivers ecology and management: lessons from the Pacific Coastal ecosystem. New York, EUA: Springer, 1998. p. 502-528.

KARR, J. R. Defining and measuring river health. Freshwater Biology, v.41, p.221234, 1999. 
KARR, J. R.; ALLAN, J. D.; BENKE, A. C. River conservation in the United States and Canada. In: BOON, P. J.; DAVIES, B. R.; PETTS, G. E. (Eds.) Global perspectives on river conservation: science, policy, and practice. New York, EUA: J. Wiley, 2000. p.3-39.

KRONKA, F. J. N. (Ed.). Inventário florestal das áreas reflorestadas do Estado de São Paulo. São Paulo, SP: Secretaria do Meio Ambiente/Instituto Florestal. 2002. s. p.

KÜIPER, J. Landscape quality based upon diversity, coherence and continuity landscape planning at different planning-levels in the River area of The Netherlands. Landscape and Urban Planning, v.43, p.91-104, 1998.

LAMMERT, M.; ALLAN, J. D. Assessing biotic integrity of streams: effects of scale in measuring the influence of land use/cover and habitat structure on fish and macroinvertebrates. Environmental Management, v.23, n.2, p.257-270, 1999.

LAMPARELLI, R. A. C.; ROCHA, J. V.; BORGUI, E. Geoprocessamento e agricultura de precisão. Fundamentos e aplicações. Série Engenharia agrícola. Guaíba, RS: Livraria e Editora Agropecuária, 2001. 118p.

LANGE JR, F. L. P. O zoneamento em APA: um novo enfoque. In: DISCUSSÃO SOBRE ÁREAS DE PROTEÇÃO AMBIENTAL ESTADUAIS - APAS. Curitiba, PR: IAP/GTZ, 1997. p.14-19.

LEITÃO FILHO, H. F. (Coord.) Estudos de ecologia da mata ciliar dos rios MogiGuaçu e Peixe-uhe, Mogi-Guaçu - SP. s.l., s.e., 1994. s.p. 
LEPSCH, I. F.; BELLINAZZI JR, R.; BERTOLINI, D.; ESPÍNDOLA, C. R. Manual para levantamento utilitário do meio físico e classificação de terras no sistema de capacidade de uso. Campinas, SP: Sociedade Brasileira de Ciência do Solo, 1983. 175p.

LIKENS, G. E. Beyond the shoreline: a watershed-ecosystem approach. Verhandlungen Internationale Verein. Limnologie, v.22, p.1-22, 1984.

LOEB, S. L.; SPACIE, A. (Ed.) Biological monitoring of aquatic systems. Boca Raton, EUA: Ed. Lewis, 1990. 381p.

LOUREIRO, W. Incentivos econômicos para conservação da biodiversidade no Brasil. Curitiba, PR. SEMA/IAP. 1998. s.p.

LOVELOCK, J. Gaia. A new look at life on Earth. Londres: Oxford University Press. 1979. 185p.

MARGALEF, R. Ecologia. Barcelona, Es: Ed. Omega, 1986. 951p.

MARIDET, L.; WASSON, J. G.; PHILIPPE, M.; AMOROS, C.; NAIMAN, R. J. Trophic structure of three streams with contrasting riparian vegetation and geomorphology. Archives für Hydrobiologie, v.144, n.1, p.61-85, 1998.

MARINHO FILHO, J. S.; REIS, M. L. A fauna de mamíferos associados às matas de galeria. In: BARBOSA, L. M. (Coord.). In: SIMPÓSIO SOBRE MATA CILIAR. Campinas, 1989, Anais. Campinas: Fundação Cargil, 1989. p.43-60 
MARTINELli, L. A.; SILVA, A. M., CAMARGO, P. B.; MORETTI, L. R.; TOMAZELLI, A. C.; SILVA, D. M. L.; FISCHER, E. G.; SONODA, K. C; SALOMÃO, M. S. M. B. Levantamento das cargas orgânicas lançadas nos rios do Estado de São Paulo. Biota Neotropica, v.2,n.2., 2002. http://www.biotaneotropica.org.br/v2n2/pt/abstract?article+BN01502022002

MCCAFFERTY, W. P. Aquatic Entomology. The fishermen's and ecologists illustrated guide to insects and their relatives. Boston, EUA: Jones \& Bartlett, 1981. 448p.

MELO, A. S.; FROEHLICH, C. G. Macroinvertebrates in neotropical streams: richness patterns along a catchment and assemblage structure between 2 seasons. Journal of the North American Benthological Society, v.20, n.1, p.1-16, 2001.

MELO, A. S.; NIYOGI, D. K.; MATTHAEI, C. R.; TOWNSEND, C. R. Resistance, resilience and patchiness of invertebrate assemblages in native tussock and pasture streams in New Zealand after a hydrological disturbance. Canadian Journal of Fisheries and Aquatic Science, v.60, p.731-739, 2003.

MELODY, K. J.; RICHARDSON, J. S. Responses of invertebrates and algae of a boreal coniferous forest stream to experimental manipulation of leaf litter inputs and shading. Hydrobiologia, v.519, p.197-206, 2004.

MENU-MARQUES, S. Karukinka fueguina n. gen. n. sp. (Copepoda, Calanoida, Centropagidae) from Tierra Del Fuego. Crustaceana, v.75, n.10, p.1229-1240, 2002.

MERRITT, R. W.; CUMMINS, K. W. (Ed.) An introduction to the Aquatic Insects of North America. Dubuque: Kendall/Hunt Publishing, 1984. 722p. 
MESSIAS, M. C. Oukuriella reissi, a new species of the genus Oukuriella Epler, 1986 (Insecta, Diptera, Chironomidae). Spixiana, v.23, n.2, p.159-161, 2000.

METCALFE, J. L. Biological water quality assessment of running water based on macroinvertebrate communities: history and present status in Europe. Environmental Pollution, v.60, n.1-2, p.101-139, 1989.

MICHAILOVA, P. V.; ILKOVA, J. \& WHITE, K. Cytogenetic alterations in Prodiamesinae species (Diptera, Chironomidae) from different polluted regions. Folia Biologica Cracow, v.51, n.1-2, p.69-79, 2003.

MIHUC, T. B.; FEMINELLA, J. W. Understanding large-river systems. Journal of the North American Benthological Society, v.20, n.2, p.223-224, 2001.

MURPHY, J. F.; GILLER, P. S. Seasonal dynamics of macroinvertebrate assemblages in the benthos and associated with detritus packs in two low-order streams with different riparian vegetation. Freshwater Biology, v.43, n.4, p.617-631, 2000.

NAIMAN, R. J.; ANDERSON, E. C. Streams and rivers: their physical and biological variability. In: SCHOOMAKER, P. K.; VON HAGEN, B.; WOLF, E. C. (Ed.). The rainforests of home. Washington D. C., EUA: Island Press, 1997. p.131-148.

NAIMAN, R. J.; DÉCAMPS, H. The ecology of interfaces: riparian zones. Annual Review of Ecological Systems, v.28, p.621-658, 1997.

NAIMAN, R. J.; BILBY, R. E. (Ed.). River ecology and management. Lessons from the Pacific Coastal Ecoregion. New York, EUA: Ed. Springer-Verlag, 1998. 705p. 
NELSON, S. M. Leaf pack breakdown and macroinvertebrate colonization: bioassessment tools for a high-altitude regulated system? Environmental Pollution, v.110, p.321-329, 2000.

NESSIMIAN, J. L. Categorização funcional de macroinvertebrados de um brejo de dunas no Estado do Rio de Janeiro. Revista Brasileira de Biologia, v.57, n.1, p.135145, 1997.

NIESER, N.; MELO, A. L. Os Heterópteros aquáticos de Minas Gerais: guia introdutório com chave de identificação para as espécies de Nepomorpha e Gerromorpha. Belo Horizonte, MG: Ed. UFMG, 1997. 180p.

NIPPER, M. G. Problemas de poluição em organismos bentônicos. In: SIMPÓSIO DE ECOSSISTEMAS DA COSTA SUL E SUDESTE BRASILEIRA: ESTRUTURA, FUNÇÃO E MANEJO, 2, São Paulo, SP, 1990. Anais. São Paulo: ACIESP, 1990. p. 24-42.

NIYOGI, D. K.; SIMON, K. S.; TOWNSEND, C. R. Breakdown of tussock grass in streams along a gradient of agricultural development: implications for ecosystem functioning and ecosystem health. Freshwater Biology, v.48, n.9, p.1698-1708, 2003.

NOVO, E. M. L. M. Sensoriamento remoto. Princípios e aplicações. São Paulo, SP: Edgard Blücher, 1992. 308p.

ODUM, E. P. Ecologia. Rio de Janeiro, RJ: Ed. Guanabara, 1983. 434p.

OLIVER, D. R. Life history of the Chironomidae In: SMITH, R. F., MITTER, T. E. (Ed.). Annual Review of Entomology, v.16, p. 211-230, 1971. 
OLIVEIRA, S. J. A new, non-marine species of the genus Thalassomya Schiner, 1856 (Insecta, Diptera, Chironomidae, Telmatogetoninae). Spixiana, v.23, n.2, p.117-120, 2000.

OMERNIK, J. M.; BAILEY, R. G. Distinguishing between watersheds and ecoregions. Journal of the American Water Research Association, v.33, n.5, p.935-949, 1997.

OMETTO, J. P. H. B.; MARTINELLI, L. A.; BALLESTER, M. V.; GESSNER, A.; KRUSCHE, A. V.; VICTORIA, R. L. \& WILLIAMS, M. Effects of land use on water chemistry and macroinvertebrates in two streams of the Piracicaba river basin, south-east Brazil. Freshwater Biology, v.44, p.327-337, 2000.

OMETTO, J. P. H. B.; GESSNER, A.; MARTINELli, L. A.; BERNARDES, M. C.; KRUSCHE, A. V.; CAMARGO, P. B. Macroinvertebrate community as indicator of land-use changes in tropical watersheds, southern Brazil. Ecohydrology and Hydrobiology, v.4, n.1, p.35-47, 2004.

ORTEGA, E. M. M. Modelos de preferência via escalonamento multidimensional. Campinas, SP. 1997. 189p. Dissertação (Mestrado) - Instituto de Matemática Estatística e Computação Científica. Universidade Estadual de Campinas.

PAYNE, A. I. The ecology of lakes and rivers. New York, EUA: Ed. Wiley, 1986. 301p.

PALMÉN, E.; LINDEBERG, B. The marine midge Clunio marinus Hal (Dipt,: Chironomidae), found in brackish water in the northern Baltic. Internationale Revue der Gesamten Hydrobiologie, v. 44, n. 3, p. 385-393, 1959. 
PAVLUK, T. I.; DE VAATE, A.; LESLIE, H. A. Development of an index of trophic completeness for benthic macroinvertebrate communities in flowing waters. Hydrobiologia, v.427, p.135-141, 2000.

PEREIRA, L. A. Análise ambiental da Bacia do Rio Itanhaém baseada na relação entre aspecto limnológicos com fisiografia, uso da terra e sistema hidrológico - SP. Rio Claro, SP. 2002. 78p. Tese (Doutorado) - Instituto de Geociências e Ciências Exatas, Universidade Estadual Paulista “Júlio de Mesquita F⿳․

PEREIRA, J. C. Avaliação da degradação ambiental de três microbacias hidrográficas da região Campos das Vertentes (MG). Lavras, MG. 1995. 81p. Dissertação (M.S.). Universidade Federal de Lavras.

PHILLIPS, D.J.H.; RAINBOW, P. S. Biomonitoring of Trace Aquatic Contaminants. New York, EUA: Elsevier Applied Science, 1993. s.p.

PINDER, L. C. V. Biology of freshwater Chironomidae. Annual Review of Entomology, v.31, p.1-23, 1986.

PINDER, L. C. V. The adult males of Chironomidae (Diptera) of the Holartic region Introduction. Entomologica scandinavia Supplement, v.34, p.5-9, 1989.

PINEL-ALLOUL, B.; MÉTHOT, G.; LAPIERRE, L.; WILLSIE, A. Macroinvertebrate community as a biological indicator of ecological and toxicological factors in lake Saint-François (Québec). Environmental Pollution, v.91, n.1, p.65-87, 1996.

PINTO, M. T. C.; MOZETO, A. A.; TOLENTINO, M. Dinâmica de nutrientes na mata ripária à Lagoa do Diogo no sistema planície de inundação do Rio Mogi-Guaçu. In: SANTOS, J. E.; PIRES, J. S. R. (Ed.) Estação Ecológica de Jataí. São Carlos, SP: RiMa Editora, 2000. p. 267-284. 
PLAFKIN, J.L.; BARBOUR, M. T.; PORTER, K. D.; GROSS, S. K.; HUGHES, R. M. Rapid assessment protocols for use in streams and rivers: benthic macroinvertebrates and fish. EPA/440/4-89-001. Washington D.C., EUA : Assessment and Water Protection Division, US Environmental Protection Agency, 1989.

PRINGLE, C. M.; NAIMAN, R. J.; BRETSCHKO, G.; KARR, J. R.; OSWOOD, M. W.; WEBSTER, J. R.; WELCOMME, R. L.; WINTERBOURN, M. J. Patch dynamics in lotic systems: the stream as a mosaic. Journal of the North American Benthological Society, v.7, n.4, p.503-524, 1988.

RESH, V. H.; ROSENBERG, D. M. The ecology of aquatic insects. New York, EUA: Praeger Publishers, 1984. 587p.

RIBEIRO, J. F.; WALTER, B. M. T.; FONSECA, C. E. L. Ecossistemas de matas ciliares. In: SIMPÓSIO DE MATA CILIAR: CIÊNCIA E TECNOLOGIA. Belo Horizonte, MG. 1999. Anais. Lavras, MG: UFLA/FAEPE/CEMIG. 1999. p. 12-24.

RICHARD, S. T.; THORNE, J.; WILLIAMS, P. The response of benthic macroinvertebrates to pollution in developing countries: a multimetric system of bioassessment. Freshwater Biology, v.37, p.671-686, 1997.

RICHARDS, C.; JOHNSON, L. B.; HOST, G. E. Landscape-scale influences on stream habitats and biota. Canadian Journal of Fisheries and Aquatic Science, v.53, n.1, p. 295-311, 1996.

RODRIGUES, R. R.; LEITÃO FILHO, H. F.; CRESTANA, M. C. Revegetação do entorno da represa de abastecimento de água do município de Iracemápolis, SP. In: SIMPÓSIO SOBRE RECUPERAÇÃO DE ÁREAS DEGRADADAS. Curitiba, PR. Anais. Curitiba, PR, 1992. s.p. 
ROQUE, F. O.; CORBI, J. J.; TRIVINHO-STRIXINO, S. Considerações sobre a utilização de larvas de Chironomidae (Diptera) na avaliação da qualidade da água de córregos do Estado de São Paulo. In: ESPÍNDOLA, E. L. G; PASCHOAL, C. M. R. B.; ROCHA, O.; BOHRER, M. B. C.; OLIVEIRA NETO, A. L. (Ed.). Ecotoxicologia. Perspectivas para o século XXI. São Carlos, SP: Ed. RiMa, 2000. p.115-126

ROSENBERG, D.M.; RESH, V. H. (Ed). Freshwater Biomonitoring and Benthic Macroinvertebrates. New York, EUA: Ed. Chapman \& Hall, 1993. 488p.

SALOMÃO, M. S. M. B. Biogeoquímica de rios do Estado de São Paulo com bacias de drenagem apresentando diferentes características de ocupação do solo. Piracicaba, SP. 2004. 125p. Tese (Doutorado) - Centro de Energia Nuclear na Agricultura, Universidade de São Paulo.

SAMWAYS, M. J.; STEYTLER, N. S. Dragonfly (Odonata) distribution patterns in urban and forest landscapes, and recommendations for riparian management. Biological Conservation, v.78, p.279-288, 1996.

SANDIN, L.; JOHNSON, R. K. The statistical power for selected indicator metrics using macroinvertebrates for assessing acidification and eutrophication of running waters. Hydrobiologia, v.422-423. p.233-243, 2000.

SANSEVERINO, A. M.; WIEDENBRUG, S. Description of the pupa of Tanytarsus cuieirensis Fittkau \& Reiss (Insecta, Diptera, Chironomidae). Spixiana, v.23, n.2, p.207-210, 2000.

SANTOS, J. E.; PIRES, J. S. R. (Ed.) Estação Ecológica de Jataí. São Carlos, SP: RiMa Editora, 2000. 867p. 
SCARSBROOK, M. R.; BOOTHROYD, I. K. G.; QUINN, J. M. New Zealand's National River Water Quality Network: long-term trends in macroinvertebrate communities. New Zealand Journal of Marine and Freshwater Research, v.34, p.289-302, 2000.

SCHIMEL, D. S. Terrestrial ecosystems and the carbon cycle. Global Change Biology, v.1, p.77-91, 1995.

SCRIMGEOUR, G. J.; TONN, W. M.; PASZKOWSKI, C. A.; AKU, P. M. K. Evaluating the effects of forest harvesting on littoral benthic communities within a natural disturbance-based management model. Forest Ecology and Management, v.126, p.77-86, 2000.

SILVA, A. D. Sistemas de Informações Geo-referenciadas: conceitos e fundamentos. Campinas, SP: Editora da Unicamp, 2003. p. 27-57.

SILVA, A. M. M.; SACOMANI, L. B. Using chemical and physical parameters to define the quality of Pardo River water. Water Research, v.35, n.6, p.1609-1616, 2001.

SILVA, A. M.; NALON, M. A.; KRONKA, F. J. N.; MARTINELLI, L. A. Land cover and relief relationship for seven meso-scale river basins in the State of São Paulo (Brazil). Submetido à Biota Neotropica.

SLIVA, L.; WILLIAMS, D. D. Buffer zone versus whole catchment approaches to studying land use impact on river water quality. Water Research, v.35, n.14, p.3462-3472, 2001. 
SONODA, K. C.; TRIVINHO-STRIXINO, S. Dinâmica da emergência de Chironomidae (Diptera) da fitofauna de Cabomba piauhyensis Gardney, 1844, na Lagoa do Infernão (Estação Ecológica de Jataí, Luiz Antônio, SP). In: SANTOS, J. E.; PIRES, J. S. R. (Ed.) Estação Ecológica de Jataí. São Carlos, SP: RiMa Editora, 2000. p. 743-754.

SONODA, K. C.; TRIVINHO-STRIXINO, S.; STRIXINO, G. Emergência de Chironomidae (Diptera) associados a tapetes de uma macrófita aquática (Cabomba piauhyensis). In: CONGRESSO BRASILEIRO DE LIMNOLOGIA, 6., São Carlos, SP. 1997. Resumos. São Carlos, SP, 1997. p.469.

SONODA, K. C.; TRIVINHO-STRIXINO, S. A new Tanytarsini from São Paulo State. (Insecta, Diptera, Chironomidae). Entomologia y Vectores. /No prelo/.

SOULSBY, C.; LANGAN, S. J.; NEAL, C. Environmental change, land use and water quality in Scotland: current issues and future prospects. The Science of the Total Environment, v.265, p.387-394, 2001.

STEWART, J. S.; WANG, L. Z.; LYONS, J.; HORWATICH, J.A.; BANNERMAN, R. Influence of watershed, riparian-corridor, and reach-scale characteristics on aquatic biota in agricultural watersheds. Journal of the American Water Research Association, v.37, n.6, p.1475-1487, 2001.

STRAYER, D. L. Macroinvertebrates of a rocky shore in the freshwater tidal Hudson River. Estuaries, v.23, n.3, p.359-366, 2000.

SUGG, P.; EDWARDS, J. S.; BAUST, J. PhenologyS and life history of Belgica antarctica, an Antarctic midge (Diptera: Chironomidae). Ecological Entomology, v.8, p.105-113, 1983. 
THIENEMANN, A., Physikalische und chemische Untersuchungen in den Maaren der Eifel, Teil 1. Verhandlungen des naturhistorischen Vereins der preußischen Rheinlande und Westfalens, v.70, p. 249-302, 1913.

THOMPSON, W. I. (Org.) Gaia: uma teoria do conhecimento. São Paulo, SP: Ed. Gaia. 1987. 203p.

THORNE, R. S. T.; WILLIAMS, P. The response of benthic macroinvertebrates to pollution in developing countries: a multimetric system of bioassessment. Freshwater Biology, v.37, p.671-686, 1997.

TICKNER, D.; ARMitAGE, P. D.; BICKERTON, M. A.; HALL, K. A. Assessing stream quality using information on mesohabitat distribution and character. Aquatic Conservation of Marine and Freshwater Ecosystems, v.10, p.179-196, 2000.

TOMAN, M. J.; STEINMAN, F. Biological assessment of organic pollution in streams. FFG, University of Ljubljana, 1995. 145p.

TOMAZELLI, A. C. Estudo comparativo das concentrações de cádmio, chumbo e mercúrio em seis bacias hidrográficas do Estado de São Paulo. Ribeirão Preto, SP. 2003. 124p. Tese (Doutorado) - Faculdade de Filosofia, Ciências e Letras de Ribeirão Preto, Universidade de São Paulo.

TONHASCA JUNIOR, A. Diversity indices in the analysis of biological communities. Ciência e Cultura, v.46, n.3, p.138-140, 1994.

TOWNSEND, C.R.; ARBUCKLE, C. J.; CROWL, T. A. \& SCARSBROOK, M. R. The relationship between land use and physicochemistry, food resources and macroinvertebrate communities in tributaries of the Taieri River, New Zealand: a hierarchically scaled approach. Freshwater Biology, v.37, p.177-191, 1997. 
TRIVINHO-STRIXINO, S.; STRIXINO, G. Larvas de Chironomidae (Diptera) dp Estado de São Paulo: guia de identificação e diagnose dos gêneros. São Carlos, SP: Ed. UFSCar, 1995. 230p.

TRIVINHO-STRIXINO, S.; STRIXINO, G. Chironomidae (Diptera) associados a troncos de árvores submersos. Revista Brasileira de Entomologia, v.41, n.2-4, p.173-178, 1998.

TROMBULAK, S. C.; FRISSELL, C. A. Review of ecological effects of roads on terrestrial and aquatic communities. Conservation Biology, v.14, n.1, p.18-30, 2000.

UENO, R.; IWAKUMA, T.; NOHARA, S. Chironomid fauna in the emergent plant zone of Lake Kasumigaura, Japan. Japanese Journal of Limnology, v. 54, n. 4, p. 293-303, 1993.

VUORI, K.; JOENSUU, I. Impact of forest drainage on the macroinvertebrates of a small boreal headwater stream: do buffer zones protect lotic biodiversity? Biological Conservation, v.77, p.87-95, 1996.

WARD, J. V. Aquatic insect ecology. 1. Biology and habitat. New York, EUA: Ed. John Willey, 1992. 437p.

WESTMANN, W. E. Ecology, impact assessment and environmental planning. New York, EUA: Ed. John Willey, 1985. 532p.

WRIGHT, I. A.; CHESSMAN, B. C.; FAIRWEATHER, P. G.; BENSON, L. J. Measuring the impact of sewage effluent on the macroinvertebrate community of an upland stream: The effect of different levels of taxonomic resolution and quantification. Australian Journal of Ecology, v.20, p.142-149, 1995. 
www.oc.fiocruz.br - Página consultada em 20 de setembro de 2004.

YOUNG, R. G.; HURYN, A. D. Effects of land use on stream metabolism and organic matter turnover. Ecological Applications, v.9, n.4, p.1359-1376, 1999. 